\title{
Sedimentology and sequence stratigraphy of the Bryne and Lulu Formations, Middle Jurassic, northern Danish Central Graben
}

\author{
Jan Andsbjerg
}

The Middle Jurassic Bryne and Lulu Formations of the Søgne Basin (northern part of the Danish Central Graben) consist of fluvially-dominated coastal plain deposits, overlain by interfingering shoreface and back-barrier deposits. Laterally continuous, mainly fining-upwards fluvial channel sandstones that locally show evidence for tidal influence dominate the alluvial/coastal plain deposits of the lower Bryne Formation. The sandstones are separated by units of fine-grained floodplain sediments that show a fining-upwards - coarsening-upwards pattern and locally grade into lacustrine mudstones. A regional unconformity that separates the lower Bryne Formation from the mainly estuarine upper Bryne Formation is defined by the strongly erosional base of a succession of stacked channel sandstones, interpreted as the fill of a system of incised valleys. Most of the stacked channel sandstones show abundant mud laminae and flasers, and rare herringbone structures, suggesting that they were deposited in a tidal environment, probably an estuary. Several tens of metres of the lower Bryne Formation may have been removed by erosion at this unconformity. The estuarine channel sandstone succession is capped by coal beds that attain a thickness of several metres in the western part of the Søgne Basin, but are thin and poorly developed in the central part of the basin. Above the coal beds, the Lulu Formation is dominated by various types of tidally influenced paralic deposits in the western part of the basin and by coarsening-upwards shoreface and beach deposits in central parts. Westwards-thickening wedges of paralic deposits interfinger with eastwards-thickening wedges of shallow marine deposits.

The Middle Jurassic succession is subdivided into nine sequences. In the lower Bryne Formation, sequence boundaries are situated at the base of laterally continuous fluvial channel sandstones whereas maximum flooding surfaces are placed in laterally extensive floodplain or lacustrine mudstones. The unconformity that separates the alluvial plain deposits of the lower Bryne Formation from the estuary deposits of the upper Bryne Formation is interpreted as a sequence boundary that bounds a system of incised valleys in the western and southern parts of the basin. Sequence boundaries in the Lulu Formation are situated at the top of progradational shoreface units or at the base of estuarine channels. Maximum flooding surfaces are located within marine or lagoonal mudstone units. Marine highstand deposits are partitioned seawards, in the eastern part of the basin, whereas paralic transgressive deposits are partitioned landwards, in the west. This marked sediment partitioning in the uppermost part of the succession resulted from the alternation of episodes of fault-induced half-graben subsidence with periods of slow uniform subsidence.

Keywords: Danish Central Graben, Middle Jurassic, Bryne Formation, Lulu Formation, sedimentology, sequence stratigraphy, alluvial/coastal plain - shallow marine, sediment partitioning

Geological Survey of Denmark and Greenland, Geocenter Copenhagen, Øster Voldgade 10, DK-1350 Copenhagen K, Denmark. E-mail: ja@geus.dk 
During the Middle Jurassic, the North Sea area was dominated by extensive coastal plain, delta plain and shallow marine environments. The resultant deposits have been described from the Viking Graben (Graue et al. 1987), from the Moray Firth and the Yorkshire coast along the western margin of the North Sea Basin (Hancock \& Fisher 1981; Rawson \& Wright 1995; Stephen \& Davies 1998), from the Norwegian-Danish Basin along the eastern margin (Nielsen 2003, this volume), and from the Central Graben in the central and southern North Sea (Gatliff et al. 1994; Herngreen et al. 2003, this volume; Fig. 1). In the past two decades, several minor gas, condensate and oil fields with Middle Jurassic reservoirs have been discovered in the Søgne Basin, a minor sub-basin straddling the Danish-Norwegian boundary line along the eastern main boundary fault of the Central Graben. Production from these fields has started recently.

The aims of this paper are threefold: (1) to provide a detailed environmental interpretation of characteristic sedimentary facies of the Middle Jurassic rocks and establish their palaeogeographic relationships; (2) to establish a high resolution sequence stratigraphic framework for the Middle Jurassic succession in the Søgne Basin of the Danish Central Graben; and (3) to describe and interpret the important reservoir rocks in the upper part of the Middle Jurassic succession, their complex inter-relationships and their relationship to surrounding rocks, and the processes that caused such complexities.

\section{Regional setting and structural development}

The Danish Central Graben forms part of the Central Graben (Fig. 1), a complex N-S-trending Mesozoic intracratonic rift basin. Subsidence of the Danish Central Graben was initiated in the Triassic but was most active during the Middle and Late Jurassic (Møller 1986). The Central Graben separates the Mid North Sea High to the
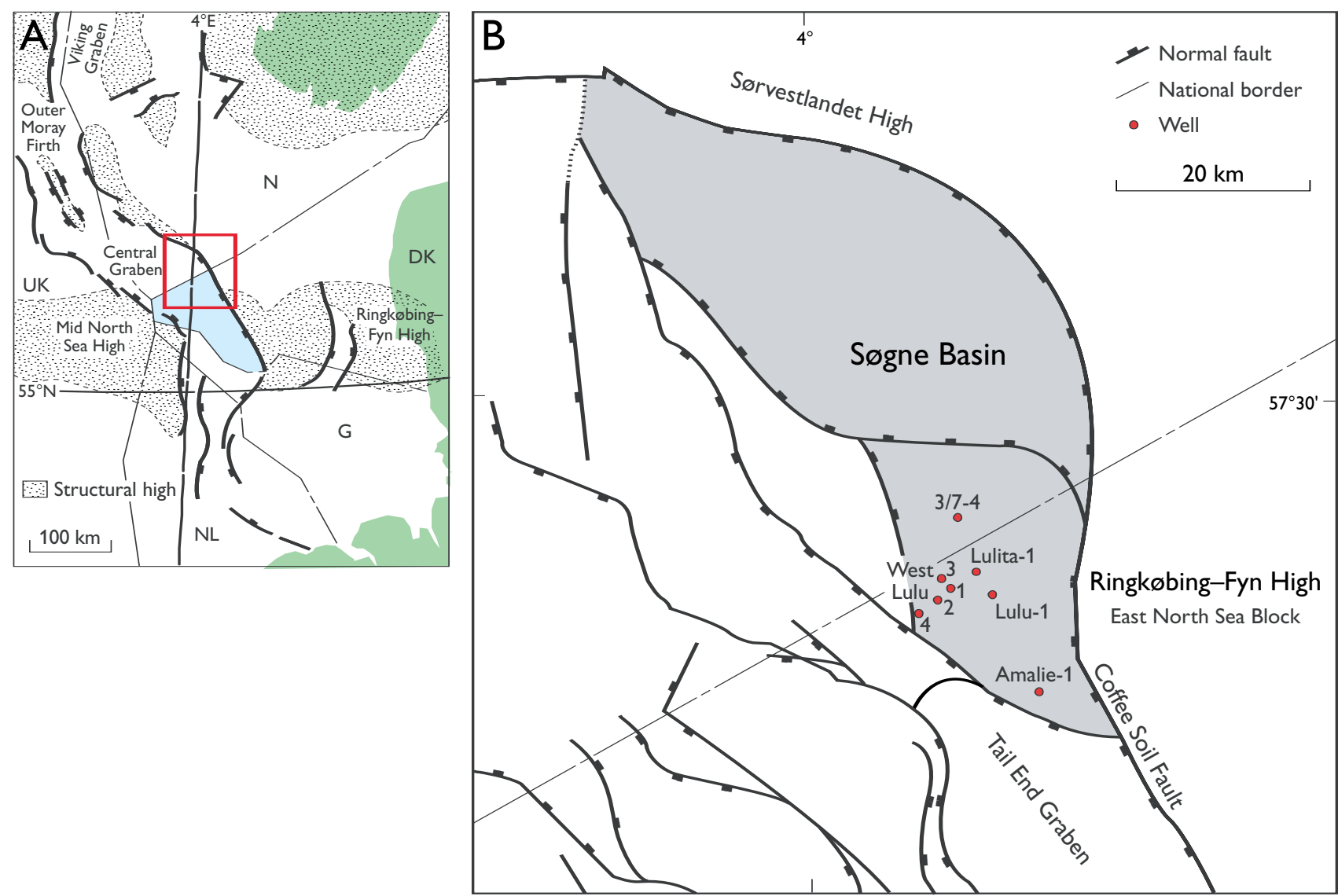

Fig. 1. A: Outline map of the Jurassic North Sea rift system showing the Danish sector of the Central Graben (blue) and the position of the map in Fig. 1B (red outline). DK, Denmark; G, Germany; N, Norway; NL, the Netherlands; UK, United Kingdom. B: Map of the northern Danish Central Graben showing the structural outline of the Søgne Basin (grey), straddling the Danish-Norwegian boundary, and the location of wells used in this study. 


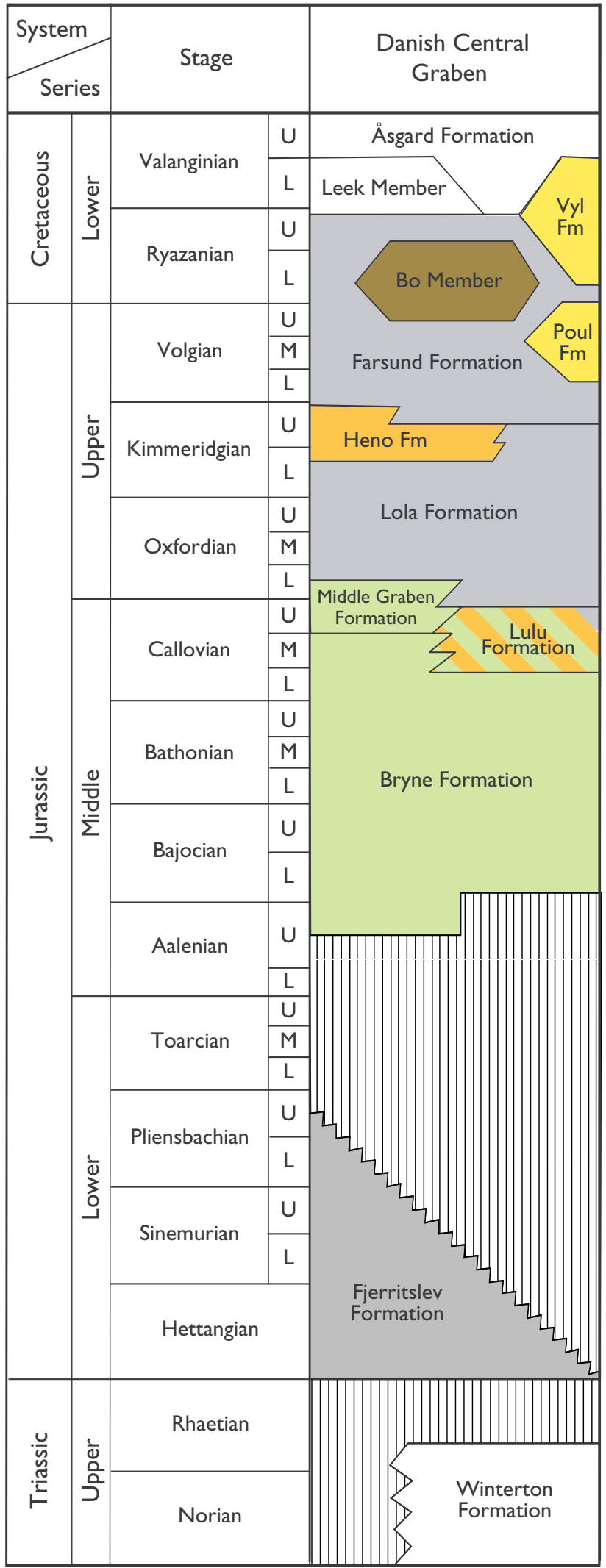

Fig. 2. Jurassic lithostratigraphy of the Danish Central Graben, from Michelsen et al. (2003, this volume).

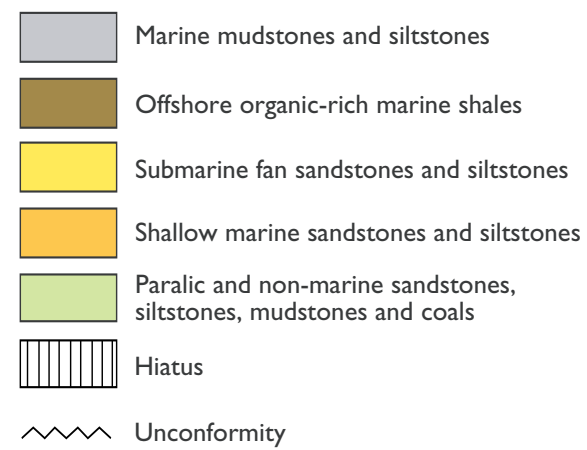

west from the East North Sea Block of the RingkøbingFyn High to the east (Japsen et al. 2003, this volume).

The development of the Danish Central Graben was determined by differential subsidence of grabens along N-S- and NW-SE-trending faults. The Søgne Basin and Tail End Graben began to subside as separate half-grabens during the Middle Jurassic (Gowers \& Sæbøe 1985; Møller 1986). Initiation of rift-associated subsidence was probably related to domal uplift and subsequent dome collapse in the North Sea area (Whiteman et al. 1975; Eynon 1981; Ziegler 1982, 1990; Underhill \& Partington 1993). Rotation probably began in the Søgne Basin in connection with boundary fault activity during the Middle Jurassic (Gowers \& Sæbøe 1985; Møller 1986; Cartwright 1991; Michelsen et al. 1992; Korstgaard et al. 1993) although it has been suggested that no syndepositional rotation took place in the Søgne Basin until Volgian time (Sundsbø \& Megson 1993). According to Mogensen et al. (1992), salt structures were generated in the Søgne Basin in the Triassic. Middle Jurassic subsidence and faulting initiated the development of boundary fault salt pillows and up-dip salt structures in the southern Søgne Basin.

\section{Stratigraphic framework, concepts and methodology}

\section{Lithostratigraphy}

Middle Jurassic sandstones with interbedded mudstones and coals were encountered by the Lulu- 1 well, the first exploration well in the Danish part of the Søgne Basin (Fig. 1). Similar deposits encountered in the Norwegian part of the Central Graben were included in the Bryne Formation, a formation erected by Vollset \& Doré (1984). Jensen et al. (1986) extended the Bryne Formation to the Middle Jurassic deposits of the northern part of the Danish Central Graben, although referring similar, coeval deposits of the southern part of the 
Danish Central Graben to the Central Graben Group of NAM \& RGD (1980). In a re-evaluation of the lithostratigraphy of the Danish Jurassic, the upper part of the Middle Jurassic succession in the northern part of the Danish Central Graben is referred to a new formation, the Lulu Formation (Fig. 2; Michelsen et al. 2003, this volume). Most of the Middle Jurassic succession in the southern part of the Danish Central Graben previously referred to the Central Graben Group is now included in the Bryne Formation, although the Middle Graben Formation, defined from the Dutch sector (see Herngreen et al. 2003, this volume), is retained in this area (Fig. 2; Michelsen et al. 2003, this volume). The boundary between the Bryne Formation and the Lulu Formation is placed at the base of the first major coal or its correlative interval of thin coals and coaly mudstones in the upper part of the middle Jurassic succession.

In the Søgne Basin, the Middle Jurassic succession unconformably overlies Triassic and Permian deposits and is either succeeded conformably by marine mudstones of the Upper Jurassic Lola Formation (Jensen et al. 1986) or is overlain unconformably by Cretaceous deposits on structural highs. In the wells of the Søgne Basin, the thickness of the Middle Jurassic succession varies from 130 to $300 \mathrm{~m}$; the succession may be absent from the top of structural highs, and it may attain a somewhat larger thickness in deeper parts of the basin.

Based on detailed sedimentological analysis of cores, the Middle Jurassic of the Lulu-1 well was interpreted as deltaic interdistributary bay deposits overlain by coastal sediments (Frandsen 1986). Koch (1983) interpreted Middle Jurassic deposits further south in the Danish Central Graben as alluvial plain and delta plain deposits. Damtoft et al. (1992) suggested a fluvial channel and floodplain environment for the Bryne Formation, and Johannesen \& Andsbjerg (1993) interpreted the Middle Jurassic succession in the Søgne Basin as an alluvial plain succession overlain by tidal and shallow marine deposits.

\section{Biostratigraphy}

Stratigraphically useful microfossils are rare in the studied succession. The sparse biostratigraphic information available for this study comes from unpublished reports from the Geological Survey of Denmark and Greenland, reports from service companies, and the results of new investigations prepared for the sequence stratigraphic study by Andsbjerg \& Dybkjær (2003, this volume). Only palynomorphs were used for dating in that study and the events are presented mainly as last occurrence datum (LOD) of dinoflagellate cyst species. The events used and their relation to boreal standard zones are presented in Andsbjerg \& Dybkjær (2003, this volume, fig. 3).

Age-specific microfossils have not been found in the lower part of the Bryne Formation in the study area. However, the occurrence of the dinoflagellate cyst Scriniocassis sp. at $3730 \mathrm{~m}$ in West Lulu-1 indicates an Aalenian or earliest Bajocian age. In the middle and upper parts of the Bryne Formation, the occurrence of the dinoflagellate cysts Ctenidodinium combazii, Impletosphaeridium varispinosum and the LOD of the pollen Quadraeculina anelliformis suggest a broad Late Bajocian to Callovian age. More specifically, the occurrence of Ctenidodinium combazii at $3742 \mathrm{~m}$ in the middle part of the Bryne Formation in West Lulu-3 suggests an age not older than Late Bajocian for that interval. The occurrence of Impletosphaeridium varispinosum in the incised valley deposits of the upper part of the Bryne Formation at $3602 \mathrm{~m}$ in West Lulu-1 and at $3705 \mathrm{~m}$ in West Lulu-3 indicates a latest Bathonian to early Callovian age. The LOD of the pollen Quadraeculina anelliformis either immediately beneath or just above the base of the incised valley deposits in several wells (e.g. $3717 \mathrm{~m}$ in West Lulu-3, $4479 \mathrm{~m}$ in Lulita-1) supports a latest Bathonian age for valley incision and the initiation of valley infilling. The Lulu Formation, which constitutes the upper part of the Middle Jurassic succession, is poorly dated. However, the occurrence of Durotrigia filapicata in the uppermost Lulu Formation at $4430 \mathrm{~m}$ in Lulita-1 suggests an age not younger than the Late Callovian, and the LOD of the dinoflagellate cyst Liesbergia scarburghensis in the lower part of the Lola Formation in several wells (Andsbjerg \& Dybkjær 2003, this volume), indicates a Late Callovian - mid-Oxfordian age for the final transgression of the Søgne Basin. With ages spanning at least a period from the Early Bajocian to the latest Callovian, the Bryne and Lulu Formations represent about $18 \mathrm{Ma}$ of deposition, according to the time-scale of Gradstein et al. (1994).

\section{Sequence stratigraphic concepts and nomenclature}

Sequence stratigraphic principles and nomenclature in this study follow Posamentier et al. (1988, 1992), Posamentier \& Vail (1988), Van Wagoner et al. (1988, 1990) and Hunt \& Tucker $(1992,1995)$.

Andsbjerg \& Dybkjær (2003, this volume) present the subdivision and naming of sequences that can be 
traced throughout the Danish Central Graben. The present study attempts a more detailed sequence stratigraphic subdivision based on key-surfaces and units that are traceable across the $\emptyset$ gne Basin. Andsbjerg \& Dybkjær (2003, this volume) subdivided the Middle Jurassic section into four sequences - the Aalen-1 (Aalenian), Baj-1, Bath-1, and Cal-1 sequences. In this higher resolution local study, this nomenclature is retained but further subdivided (Fig. 3). Thus, Cal-1 of Andsbjerg \& Dybkjær (2003, this volume) is divided into Cal-1A,

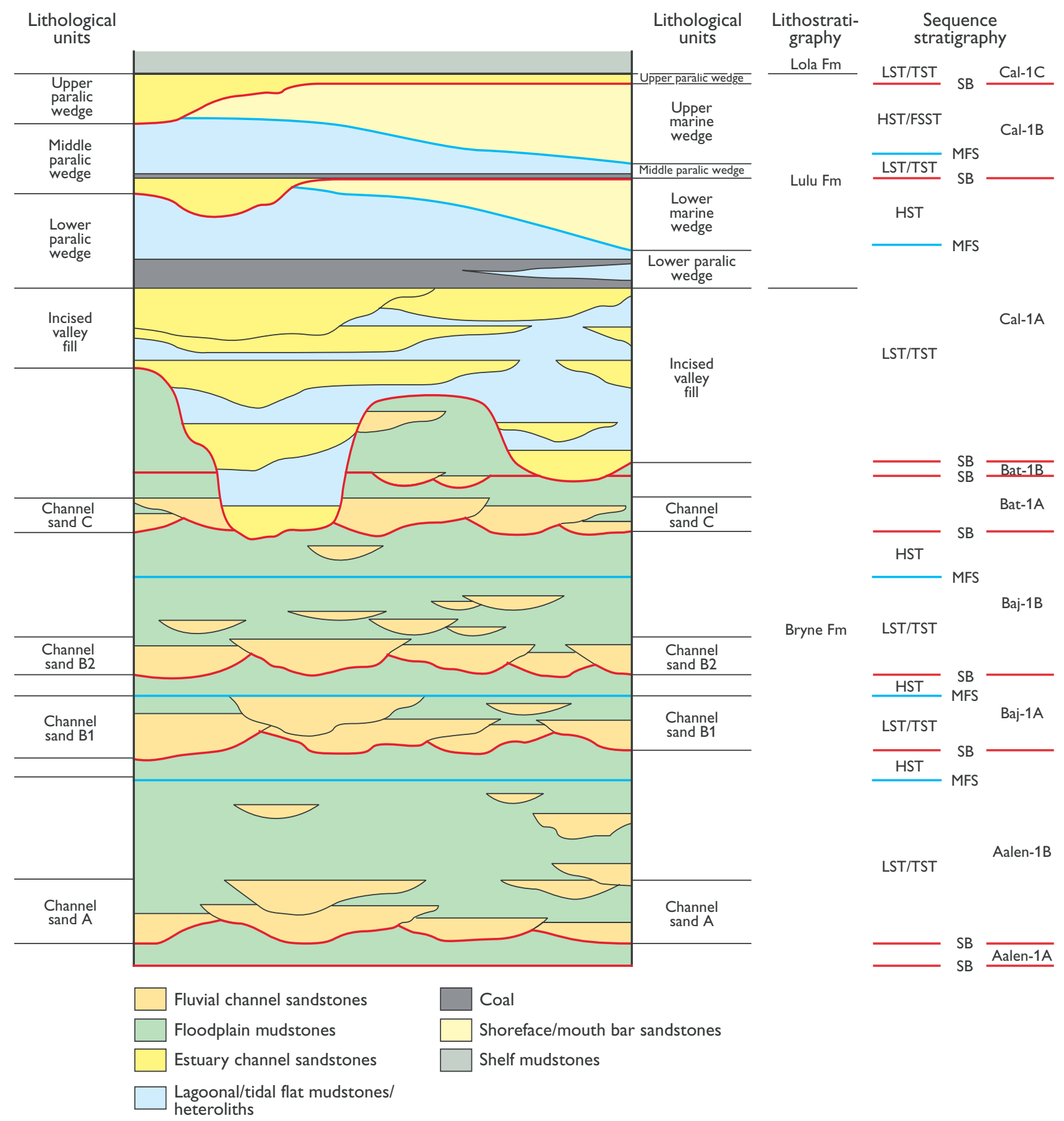

Fig. 3. Architecture, lithostratigraphy and sequence stratigraphic interpretation of the Middle Jurassic in the northern part of the Danish Central Graben. The Middle Jurassic sequences defined in this study are referred to according to their gross age, i.e. Callovian sequences are termed Cal-1A, Cal-1B etc. System tracts: LST, lowstand systems tract; TST, transgressive systems tract; HST, highstand systems tract; FSST, falling stage systems tract. Key surfaces: SB, sequence boundary; MFS, maximum flooding surface. 
Cal-1B and Cal-1C. The sequences and their most important key surfaces are shown in Figures 3 and 4 . The hierarchical nature of sequence stratigraphy, i.e. the potential subdivision of larger sequences into a number of smaller sequences, reflects the fact that sequences represent the varying time-spans over which different combinations of causal factors may operate. Influenced by a variety of factors such as glacio-eustacy, tectono-eustacy, tectonics of various scales, and climate, sequences form over time scales ranging from tens of thousands of years to hundreds of millions of years (see discussion in Vail et al. 1977, Van Wagoner et al. 1990, Miall 1997). Whereas the Middle Jurassic sequences outlined by Andsbjerg \& Dybkjær (2003, this volume) represent time-spans of 5-10 Ma. which is consistent with the influence of intraplate stress (Cloetingh 1988; Hallam 1988; Miall 1997), the present study identifies sequences with durations in the range 1-5 Ma., which may indicate a stronger influence of local tectonics.

\section{Key surfaces and systems tracts}

A systems tract is defined as a linkage of contemporaneous depositional systems defined by stratal geometry at bounding surfaces, position within the sequence, and internal stacking patterns (Posamentier et al. 1988). Sequences are subdivided into the lowstand systems tract (LST), the transgressive systems tract (TST), the highstand systems tract (HST) and the falling stage systems tract (FSST; alternatively termed the forced regressive systems tract by Hunt \& Tucker 1992, 1995). The lowstand systems tract (LST) consists of deposits formed at the lowest relative sea-level stand, bounded below by the mainly subaerial sequence-bounding unconformity (SB) and above by the first transgressive surface (TS). The TST consists of a succession of backstepping parasequences; individual parasequences may exhibit a progradational pattern. The lower boundary of the TST is the first TS and the upper boundary is the maximum flooding surface (MFS). The HST is characterised by a progradational stacking pattern, which may be interrupted by subordinate transgressive events. The systems tract is bounded at the base by the MFS and at the top by the $\mathrm{SB}$ or by a regressive surface of marine erosion (RSME) if it is overlain by a falling stage systems tract (FSST). The FSST consists of the sediments deposited during falling sea level and is bounded by the RSME at the base and by the SB at the top.

There is a direct link between sequence development and relative sea-level change in the marine and marginal marine realm. In upland settings, sea-level changes do not influence sequential development of deposition significantly. A more pronounced influence may be present in non-marine deposits of lowland settings, although it may be subordinate to other factors. The sporadic occurrence of tidal indicators in the non-marine deposits of the Bryne Formation suggests that deposition took place on the lower part of a coastal plain where sea-level changes may have exerted a strong influence on sedimentation patterns and sequence development.

\section{Data and methodology}

Data from 9 released wells penetrating the Bryne Formation in the Søgne Basin were used in the present study (Fig. 1). A total of $875 \mathrm{~m}$ of core has been examined and described. Graphic core logs were matched to gamma-ray (GR) and sonic logs, supplemented by density, neutron and resistivity logs, in order to gain an improved interpretation of the cored successions. The observed core-to-log relationships have been used in the interpretation of well logs from uncored intervals by extrapolating sedimentological interpretations of cores to the uncored sections. The well logs and sedimentological core logs formed the basis for the construction of cross-sections. Well-to-well correlations of key surfaces and characteristic units form a framework that guide correlations of other units and form the basis for the construction of palaeogeographic maps.

\section{Sedimentary facies and depositional environments}

Approximately $875 \mathrm{~m}$ of slabbed cores were available for the description of sedimentary facies. Facies descriptions include the registration of lithology, grain size, primary sedimentary structures and deformation structures including degree and type of bioturbation. A total of 30 facies are recognised (Table 1) and are grouped into nine facies associations (1-9), each of which represents a specific sedimentary environment.

\section{Non-marine deposits}

Sediments interpreted as mainly non-marine dominate the lower and middle part of the Bryne Formation. They are grouped into four facies associations repre- 


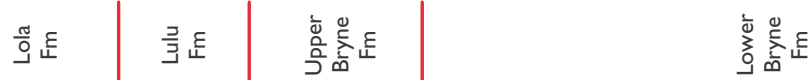

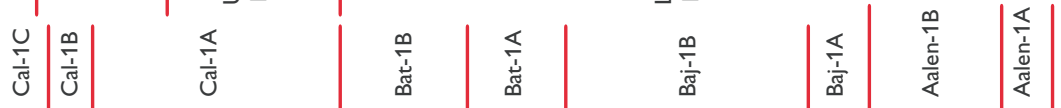

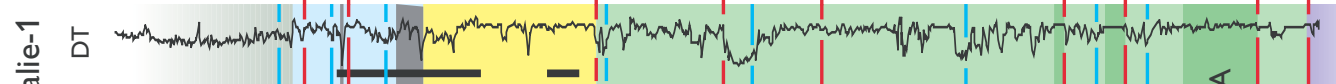

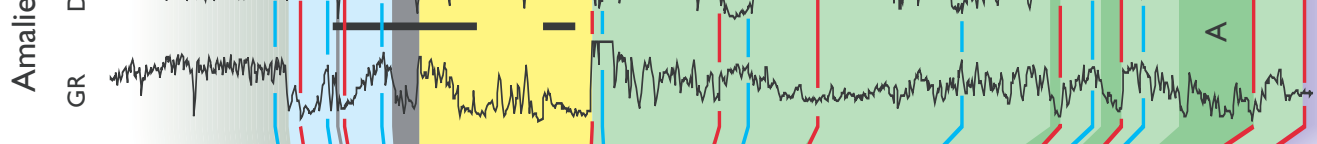

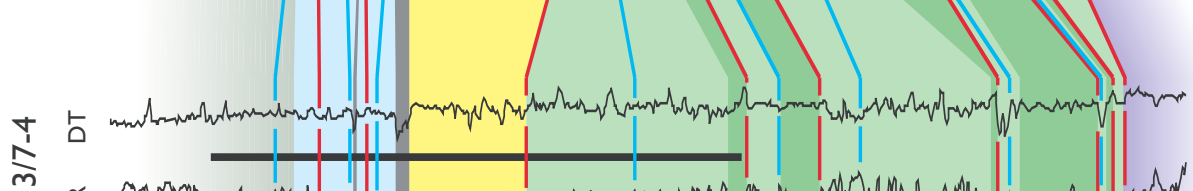

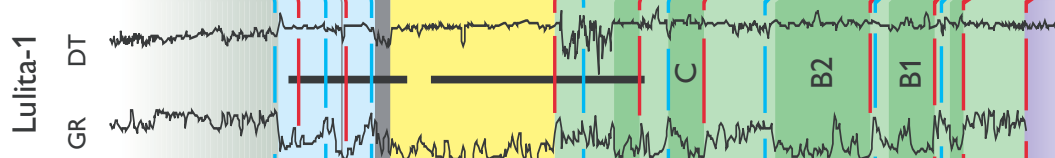

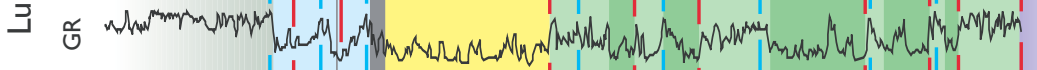

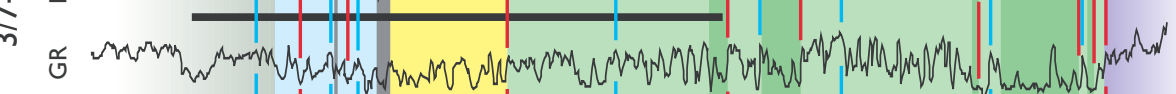

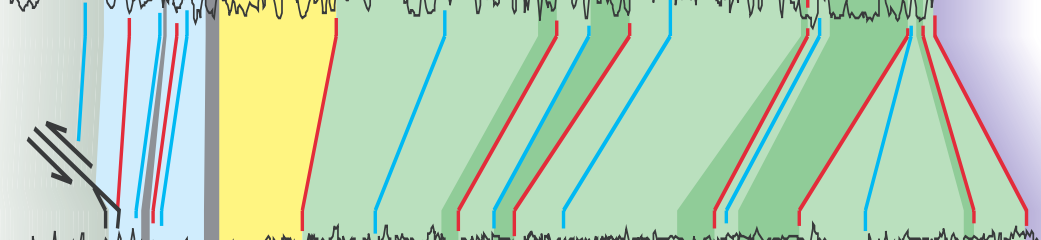

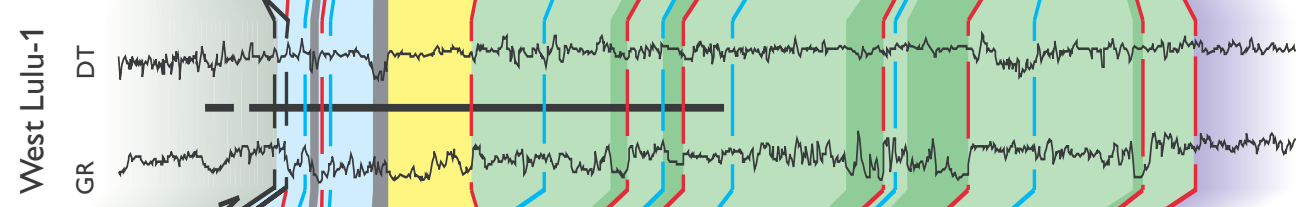

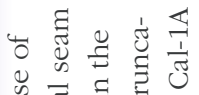

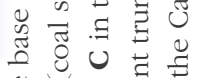

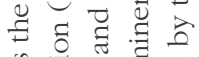

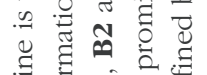

छ现实导

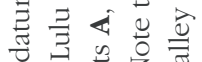

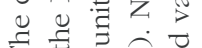

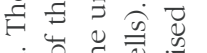

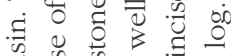

๓

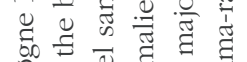

क ⿱ 口)

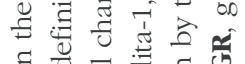

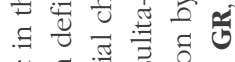

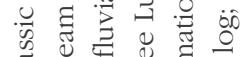

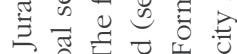

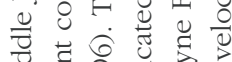

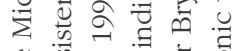

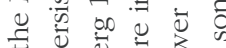

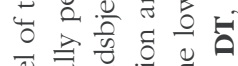

च च्ञ

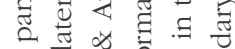

00 过

三

च है

ن

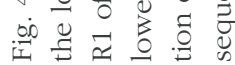
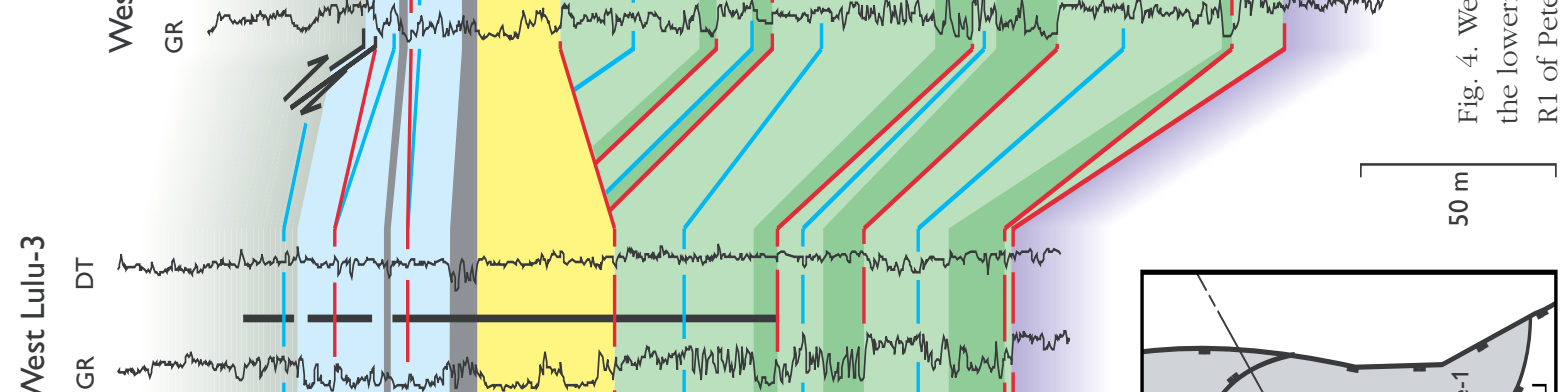

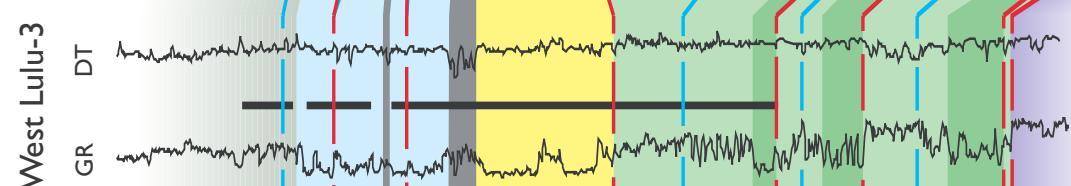

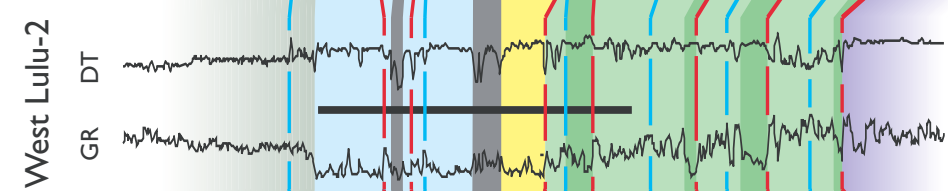

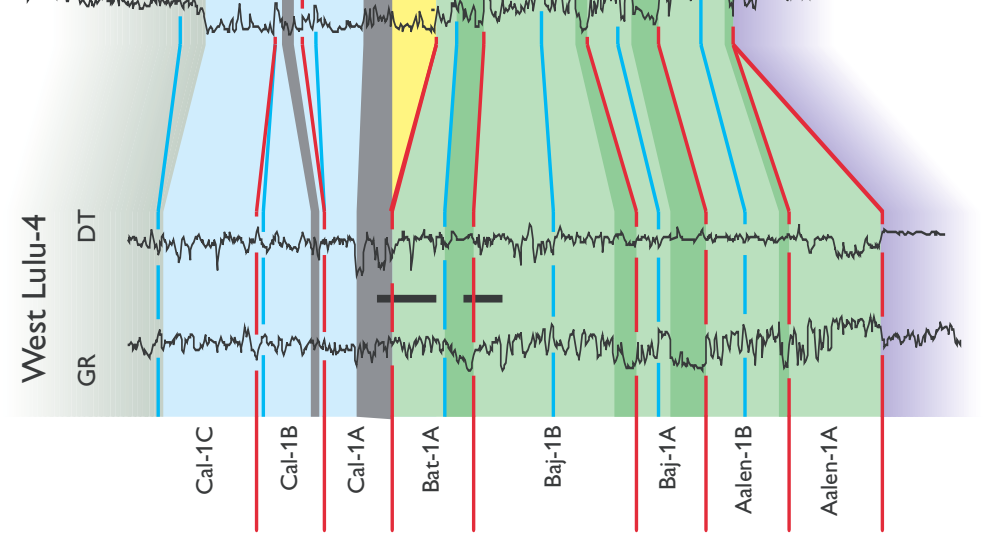

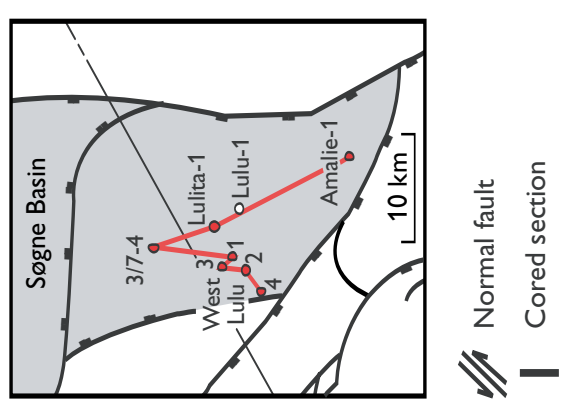

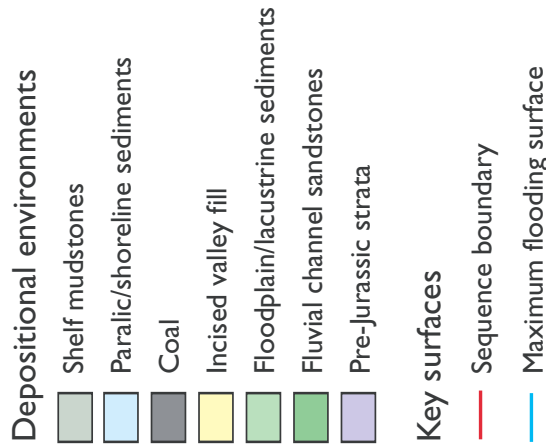


Table 1. Facies classification of the Bryne and Lulu Formations

\begin{tabular}{|c|c|c|}
\hline & Facies & Description \\
\hline 1 & $\begin{array}{l}\text { Structureless and laminated } \\
\text { siltstone and claystone }\end{array}$ & Structureless or $\mathrm{mm}$ - to $\mathrm{cm}$-scale interlaminated siltstone and claystone \\
\hline 2 & $\begin{array}{l}\text { Interbedded siltstone and } \\
\text { sandstone }\end{array}$ & $\begin{array}{l}\text { Cm-scale interbedded siltstone and sandstone. Sharp-based, normal graded sand } \\
\text { laminae show parallel lamination and wave ripples }\end{array}$ \\
\hline
\end{tabular}

3 Bioturbated siltstone and sandstone

4 HCS-dominated sandstone

5 SCS-dominated sandstone

6 Trough and planar crossbedded sandstone

7 Horizontally laminated and planar cross-bedded sandstone

8 Conglomerate and pebbly sandstone

9 Poorly sorted, bioturbated muddy sandstone and heterolith

10 Horizontally laminated and current rippled sandstone

11 Structureless rooted sandstone

12 Fining-upwards cross-bedded sandstone with mud drapes

13 Fining-upwards interbedded mudstone and sandstone

14 Coarsening-upwards sandstone with abundant mud laminae

15 Coarsening-upwards cross-bedded sandstone with mud laminae

16 Fining-upwards heterolithic sandstone and mudstone
Bioturbated siltstone, very fine-grained sandstone beds with sharp bases may show wave or combined flow ripples, parallel lamination and HCS

Very fine- and fine-grained sandstone with siltstone laminae. Sharp-based sandstone beds with HCS and subordinate wave ripple lamination

Fine-grained sandstone, SCS, low-angle planar cross-bedding and scour structures

Fine- to coarse-grained sandstone, occasionally pebbly. Trough cross-bedding, planar cross-bedding and subordinate current and wave ripples

Fine- to coarse-grained sandstone. Parallel lamination with low-angle erosion surfaces and low-angle planar cross-bedding

Clast-supported pebble and granule conglomerate, less common matrix-supported conglomerate and pebbly sandstone. Clast-supported conglomerate may show crossbedding; conglomerate veneers on erosion surfaces

Poorly sorted sandstone with subordinate siltstone. Soft-sediment deformation structures and bioturbation dominate, some wave and current ripples may occur

Erosionally based fining-upwards units of very fine- to medium-grained sandstone. Parallel or gently inclined lamination, current ripples, local soft-sediment deformation structures or high-angle cross-bedding

Various sandstones and heteroliths fully or partly homogenised by roots

Fining-upwards units of fine- to coarse-grained sandstone. Planar and trough crossbedding with ripple cross-laminated flaser and wavy bedding in upper parts of units. Abundant clay laminae; clay clasts and coal debris, interbedded sandstone and mudstone may occur

Fine- and very fine-grained sandstone and heteroliths with mud clasts. Ripple crosslamination, parallel lamination, flaser, lenticular and wavy bedding, cross-bedding

Very fine- to fine-grained sandstone. Bioturbated with mud laminae and flasers, ripple cross-lamination

Very fine- to medium-grained sandstone and heteroliths. Cross-bedding, crosslamination, flaser bedding, mud laminae

Thinly interbedded sandstone, mudstone and heteroliths. Ripple cross-lamination, parallel lamination, flaser bedding 


\begin{tabular}{|c|c|c|}
\hline Thickness & Biogenic structures & Interpretation \\
\hline Beds $<50 \mathrm{~cm}$ & & $\begin{array}{l}\text { Offshore, fair-weather deposition and } \\
\text { suspension fall-out after storms }\end{array}$ \\
\hline Beds max. $10 \mathrm{~cm}$ & $\begin{array}{l}\text { Weak to moderate bioturbation: } \\
\text { Anconichnus isp., Planolites isp. and } \\
\text { Teichichnus isp. }\end{array}$ & Offshore, near storm wave base \\
\hline $\begin{array}{l}\text { Silt beds less than } 3 \mathrm{~m} \text {, } \\
\text { sand beds up to } 10 \mathrm{~cm} \text {, } \\
\text { rarely to } 50 \mathrm{~cm}\end{array}$ & $\begin{array}{l}\text { Moderate to intense bioturbation: } \\
\text { Teichichnus isp., Thalassinoides isp., } \\
\text { Skolithos isp., Planolites isp. }\end{array}$ & $\begin{array}{l}\text { Offshore - offshore transition, } \\
\text { storm activity alternating with } \\
\text { long periods dominated by fair-weather conditions }\end{array}$ \\
\hline $10-50 \mathrm{~cm}$ beds & Weak bioturbation & $\begin{array}{l}\text { Offshore transition, storm and } \\
\text { waning storm deposition }\end{array}$ \\
\hline $20-50 \mathrm{~cm}$ beds & Trace fossils are rare & $\begin{array}{l}\text { Lower and middle shoreface, } \\
\text { above fair-weather wave base }\end{array}$ \\
\hline $\begin{array}{l}20-50 \mathrm{~cm} \text { beds in units } \\
\text { up to } 3 \mathrm{~m}\end{array}$ & $\begin{array}{l}\text { Bioturbation in the most fine-grained } \\
\text { intervals: Diplocraterion isp. and Skolithos isp. }\end{array}$ & $\begin{array}{l}\text { Upper shoreface. Rip channels, } \\
\text { nearshore bars and troughs }\end{array}$ \\
\hline $\begin{array}{l}5-15 \mathrm{~cm} \text { beds in units } \\
\text { up to } 50 \mathrm{~cm}\end{array}$ & $\begin{array}{l}\text { Trace fossils are rare: } \\
\text { roots and (?)Skolithos isp. }\end{array}$ & Foreshore \\
\hline $\begin{array}{l}\text { Conglomerate beds } \\
\text { max. } 10 \mathrm{~cm} \text {, pebbly } \\
\text { sandstone beds up to } 30 \mathrm{~cm}\end{array}$ & & $\begin{array}{l}\text { Beach and breaker zone deposits. } \\
\text { May represent a transgressive lag }\end{array}$ \\
\hline $\begin{array}{l}5-10 \mathrm{~cm} \text { beds in units } \\
\text { up to } 1 \mathrm{~m}\end{array}$ & $\begin{array}{l}\text { Often thoroughly bioturbated: } \\
\text { Teichichnus isp., Diplocraterion isp. }\end{array}$ & $\begin{array}{l}\text { Transgressive marine sandstone deposited below } \\
\text { fair-weather wave base during rising sea level }\end{array}$ \\
\hline $5-20 \mathrm{~cm}$ beds & Moderate bioturbation, roots may occur & Washover sediments \\
\hline $50 \mathrm{~cm}-3 \mathrm{~m}$ & Thoroughly homogenised by roots & Beach ridge plain \\
\hline 4-10 m fining-upwards units & $\begin{array}{l}\text { Moderate, rarely intense bioturbation: } \\
\text { Teichichnus isp. }\end{array}$ & Major tidal channel or active tidal inlet \\
\hline $\begin{array}{l}\text { Fining-upwards units } \\
\text { typically } 50 \mathrm{~cm}-2.5 \mathrm{~m}\end{array}$ & Moderate to intense bioturbation & Tidal creek or inactive major tidal channel \\
\hline $\begin{array}{l}\text { Coarsening-upwards units } \\
\text { up to } 2 \mathrm{~m}\end{array}$ & $\begin{array}{l}\text { Moderate to intense bioturbation: } \\
\text { Teichichnus isp. }\end{array}$ & Tidal sand bar/flat \\
\hline $\begin{array}{l}\text { Coarsening-upwards units } \\
\text { up to } 4 \mathrm{~m}\end{array}$ & $\begin{array}{l}\text { Generally moderate bioturbation: } \\
\text { Teichichnus isp., Diplocraterion isp. }\end{array}$ & Proximal flood tidal delta or estuary sand bar \\
\hline Units less than $1 \mathrm{~m}$ & $\begin{array}{l}\text { Moderate to intense bioturbation: } \\
\text { common Diplocraterion isp., Planolites isp. }\end{array}$ & Tidal flat and distal flood tidal delta \\
\hline
\end{tabular}


Table 1 (continued). Facies classification of the Bryne and Lulu Formations

\begin{tabular}{ll}
\hline Facies & Description \\
\hline 17 Coarsening-upwards/fining-upwards & $\begin{array}{l}\text { Coarsening-upwards very fine- to medium-grained sandstone units. Planar cross- } \\
\text { sandstone and heterolith }\end{array}$ \\
& bedding, parallel lamination, current and wave ripple cross-lamination and small-scale \\
& HCS/SCS. Commonly associated with fining-upwards channel units
\end{tabular}

18 Structureless or laminated mudstone and bioturbated sandstone

19 Organic-rich rooted mudstone

20 Coal

21 Fining-upwards interbedded sandstone and mudstone

22 Sandstone, fining-upwards or no grain-size trend

23 Intraformational conglomerate

24 Fining-upwards thin-bedded or cross-bedded sandstone

25 Chaotically bedded sandstone

26 Sideritic siltstone and mudstone

27 Coarsening-upwards units of deformed siltstone and sandstone

28 Coarsening-upwards units of sharp-based sandstone and siltstone

29 Disturbed silty mudstone

30 Organic-rich laminated mudstone
Parallel-laminated or structureless mudstone with interbeds and laminae of sandstone. Parallel lamination, wave ripples, flaser and lenticular bedding

Organic-rich mudstones with plant fragments, thin coals and with abundant rootlets

Sharp-based units, often fining-upwards, of cross-bedded and cross-laminated sandstone with abundant heterolithic beds and mud laminae. Abundant coal or mud clasts locally

Sharp-based fining-upwards cross-bedded and cross-laminated sandstone. Heterolithic sandstones may dominate upper part of units; some beds may have abundant coal and mud clasts. Thick amalgamated units may show no overall grain-size trend

Matrix- or clast-supported, pebble-cobble conglomerate, with sand matrix. Angular mud- or siltstone clasts. Conglomerate beds at base of fining-upwards sandstone units are parallel-stratified or cross-bedded

Sharp-based fining-upwards sandstones. Thin-bedded with current ripple crosslamination, parallel lamination or cross-bedding. Intraformational clasts and coa fragments, soft-sediment deformation

Poorly sorted sandstone with deformed and overturned mud laminae. Coal and mud clasts scattered throughout

Siltstone and mudstone with siderite bands and nodules, abundant plant remains and roots. Indistinct patches of sandstone may occur

Stacked coarsening-upwards units of siltstone and sandstone. Dominated by softsediment deformation structures with current, wave, and climbing ripple lamination in sandstone units, parallel and climbing ripple lamination and wavy and lenticular bedding in siltstone units. Mudstone clasts and coal fragments locally abundant. Thinner, sharp based fining-upwards sandstones with deformed cross-bedding may occur at top of coarsening-upwards intervals

Coarsening-upwards units of very fine- to medium-grained sandstone with silt- and mudstone. Common parallel lamination, current ripple cross-lamination, root traces, soft-sediment deformation. Base gradational to floodplain mudstones

Mud- and siltstone, subordinate sandstone, coal debris. Parallel lamination, sediments disturbed by roots, soft-sediment deformation and pedogenesis 


\begin{tabular}{|c|c|c|}
\hline Thickness & Biogenic structures & Interpretation \\
\hline Units up to $5 \mathrm{~m}$ & $\begin{array}{l}\text { Moderately bioturbated: Teichichnus isp., } \\
\text { Diplocraterion isp. }\end{array}$ & Bay-head delta/bay shoreface \\
\hline Units less than $2 \mathrm{~m}$ & Moderate to intense bioturbation by roots & $\begin{array}{l}\text { Low energy outer estuary, estuary } \\
\text { central basin or lagoon }\end{array}$ \\
\hline Less than $50 \mathrm{~cm}$ & Moderate to intense bioturbation by roots & Marsh or vegetated coastal swamp \\
\hline Max. $5 \mathrm{~m}$ & & Mire \\
\hline Units max. $12 \mathrm{~m}$ & $\begin{array}{l}\text { Upper part of channel units may be } \\
\text { bioturbated: Diplocraterion isp., Teichichnus isp. }\end{array}$ & Tidally influenced fluvial channel \\
\hline Units max. $8 \mathrm{~m}$ & & Major fluvial channel \\
\hline Beds up to $75 \mathrm{~cm}$ & & Channel lag deposits \\
\hline Units $<2 \mathrm{~m}$ & & Crevasse channel or minor fluvial channel \\
\hline Beds typically $20-50 \mathrm{~cm}$ & & Channel margin deposits of fluvial channels \\
\hline Typically $0.5-2 \mathrm{~m}$ & & Abandoned channel fill \\
\hline $\begin{array}{l}2-5 \mathrm{~m} \text { units. May be } \\
\text { stacked in } 10 \mathrm{~m} \\
\text { coarsening-upwards } \\
\text { successions }\end{array}$ & & $\begin{array}{l}\text { Lacustrine delta. Stacked minor coarsening- } \\
\text { upwards units capped by channel sandstones } \\
\text { may represent delta lobes of a larger } \\
\text { lacustrine delta }\end{array}$ \\
\hline $\begin{array}{l}\text { Beds } 10-50 \mathrm{~cm} \\
\text { units up to } 2 \mathrm{~m}\end{array}$ & & Levee and crevasse spray \\
\hline Typically $<1 \mathrm{~m}$ & Thoroughly bioturbated, mainly by roots & Floodplain fines \\
\hline Max. 8 m & & Lake and pond \\
\hline
\end{tabular}


A

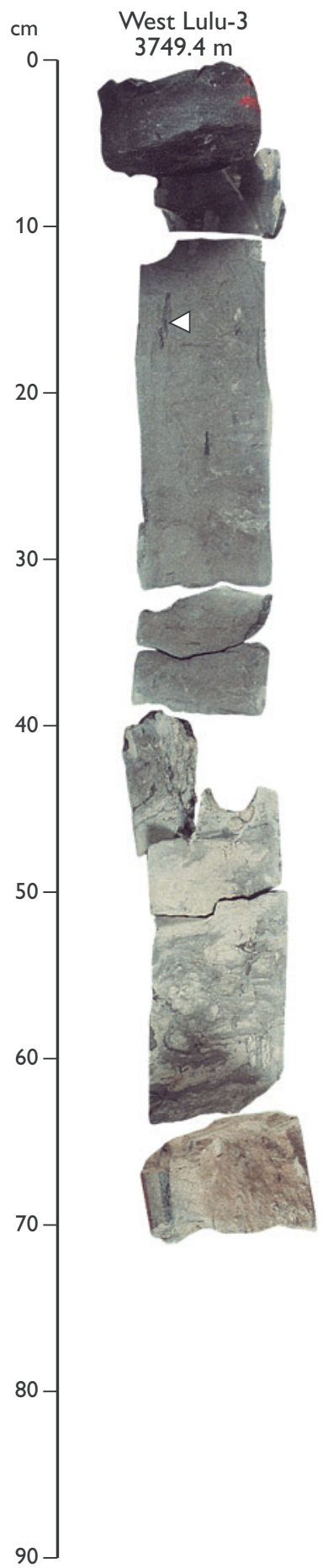

C

\section{West Lulu-3} $3751 \mathrm{~m}$
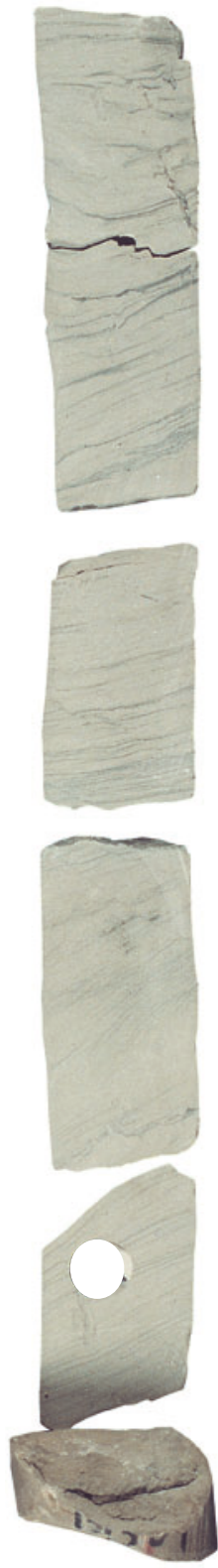

West Lulu-3 $3751.8 \mathrm{~m}$
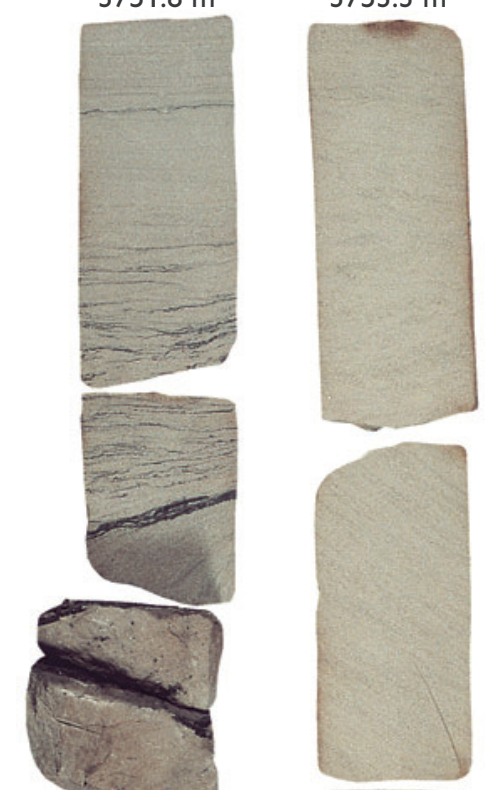

West Lulu-3 $3753.3 \mathrm{~m}$
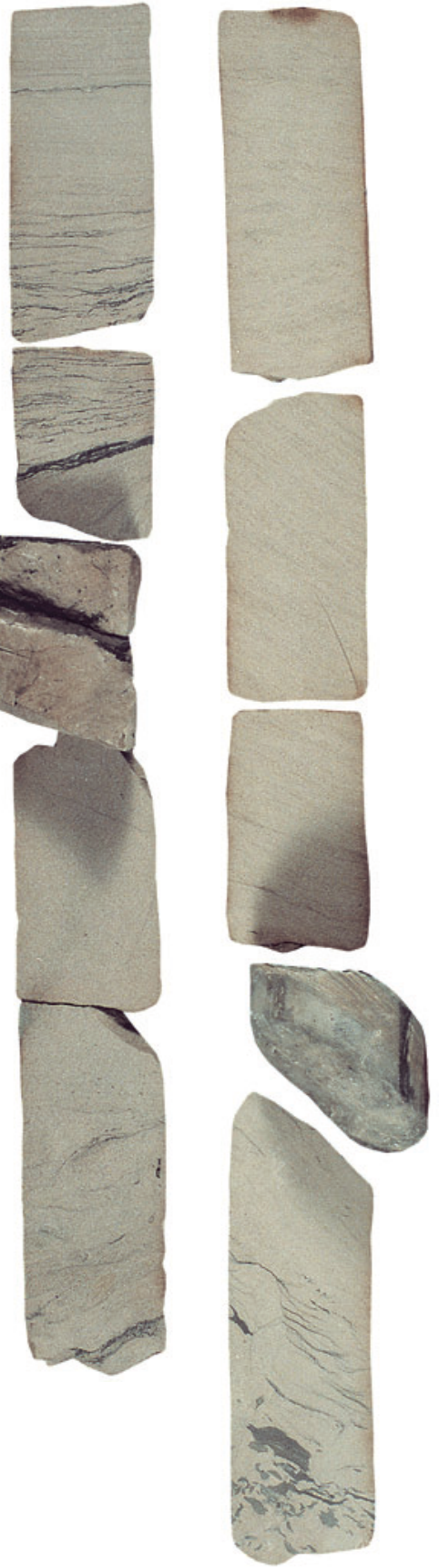

E

West Lulu-3 $3754.1 \mathrm{~m}$
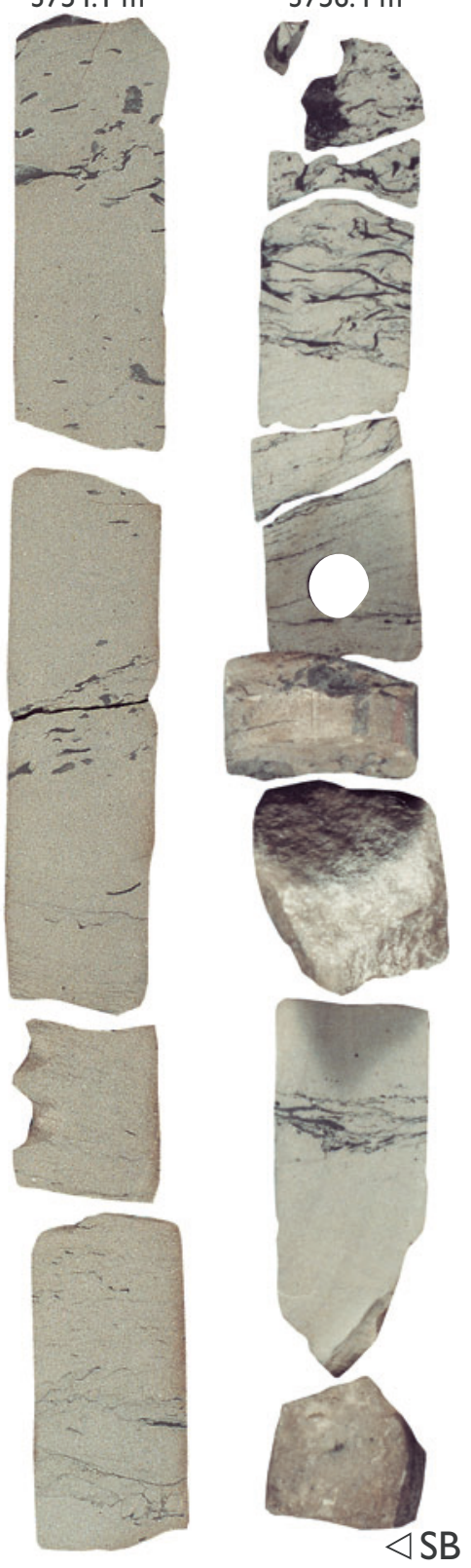

This page and facing page:

Fig. 5. Core photographs of fluvial channel and floodplain facies (facies associations 1-4) and facies successions of the lower Bryne Formation (Baj-1B, Bat-1A, Bat-1B sequences). Consecutive core sections in this and subsequent core photographs are bracketed. A-F: Selected intervals of the fluvial channel unit B2 (sequence Baj-1B, LST/TST) in West Lulu-3 (base lower right, top upper left; for location of core sections, see Fig. 13). The basal sequence boundary (SB) overlying sequence Baj-1A lies immediately beneath the lowermost core section (F). Sections B-F illustrate the active channel fill (facies association 1), showing trough cross-bedded, ripple cross-laminated and structureless sandstones, with abundant coal and mudstone clasts. These are succeeded (A) by passive channel fill or floodplain deposits (facies associations 2, 4) comprising mudstones, interbedded mudstones and sandstones and thin coals associated with rootlets 
G

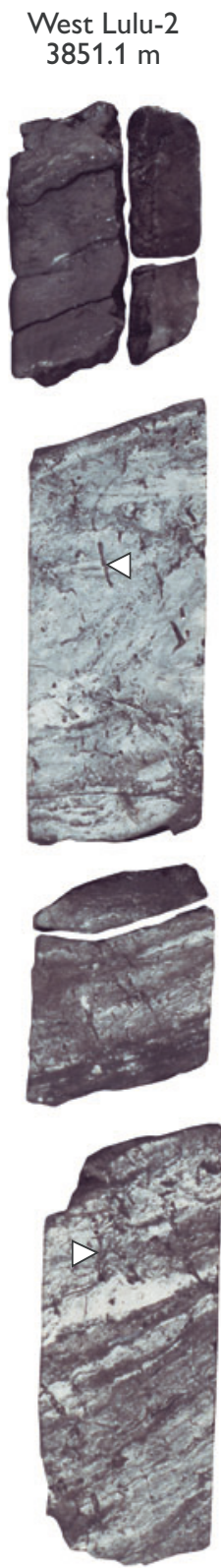

$\mathrm{H}$
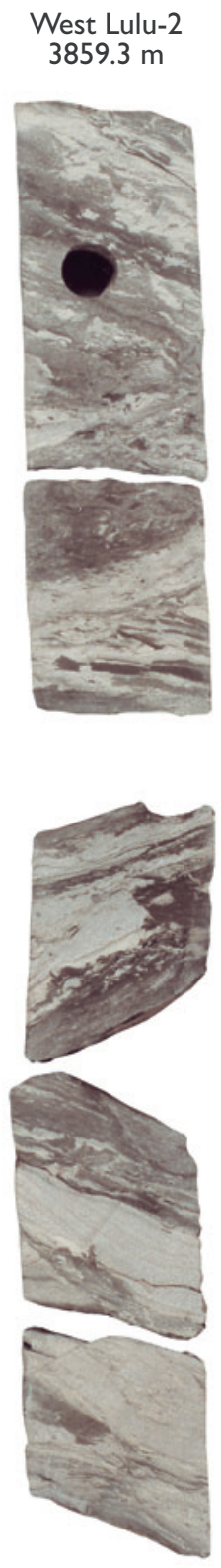

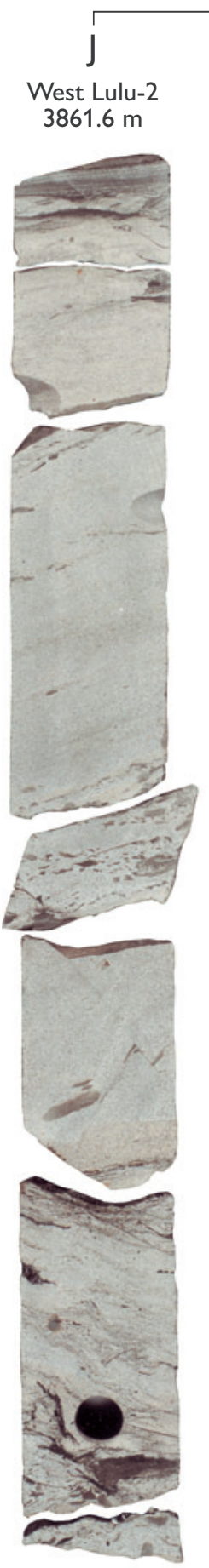

L

West Lulu-1

West Lulu-2

$3862.2 \mathrm{~m}$
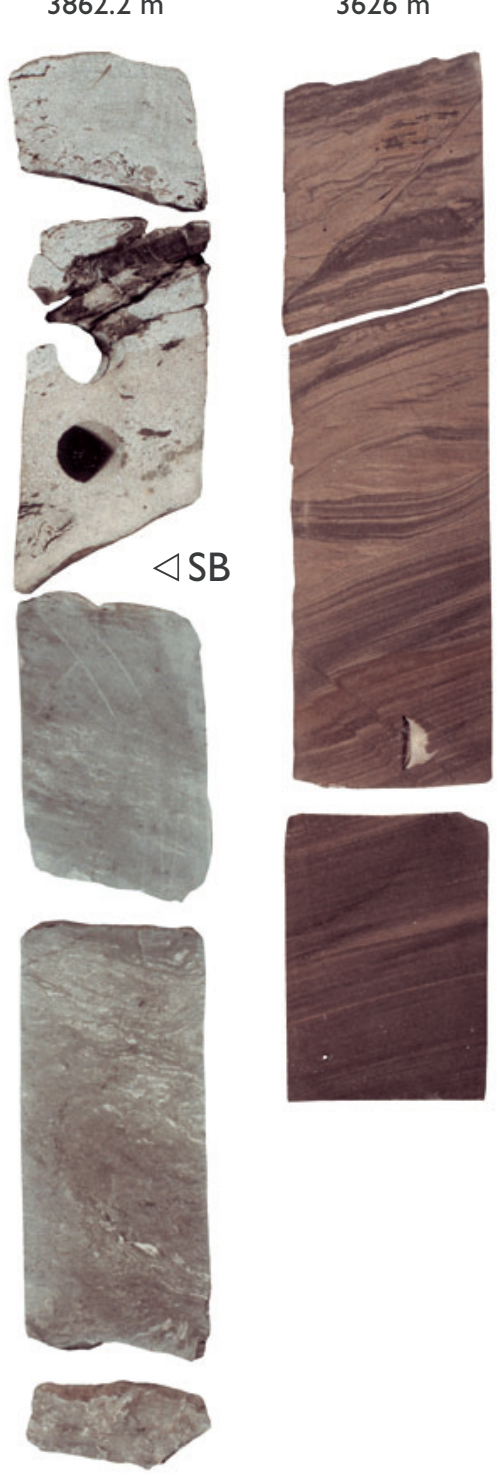

$-10$

$-20$

$-30$

$-40$

$-50$

$\mathrm{cm}$

0
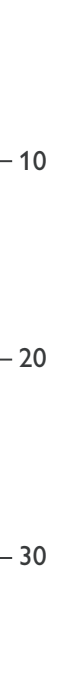

$-60$

$-70$

$-80$

90

(arrowed) and palaeosol mottling. G-K: Selected intervals from the fluvial channel sandstone unit C (sequence Bat-1A) in West Lulu-2 (base lower right, top upper left; for location of core sections, see Fig. 14). The channel base defining the sequence boundary (SB, see core section $\mathbf{K}$ ) is overlain by the active channel fill (facies association 1) comprising structureless and cross-bedded sandstones with abundant mudstone clasts and coal fragments ( $\mathbf{I}-\mathbf{K}$, lower point bar) succeeded by sandstone and mudstone heteroliths, disturbed in places by bioturbation (rootlets arrowed) and soil-forming processes (G, $\mathbf{H}$; upper point bar). The channel fill is capped by coal (G; facies association 4). L: Sandstone and heterolithic sandstones showing climbing ripple cross-lamination, representing a lacustrine or crevasse delta (facies association 2). West Lulu-1, sequence Bat-1B; for location of core section, see Fig. 15. 
senting fluvial channel fill, proximal floodplain, lake and distal floodplain, and vegetated floodplain.

\section{Facies association 1: fluvial channel fill (facies 21-26)}

Description. The fluvial channel fill association comprises erosionally based, up to $8 \mathrm{~m}$ thick, fining-upwards, channel units. The channel units are dominated by sandstone in the lower part and become heterolithic in the upper part (Fig. 5B-F). A conglomerate of mudstone clasts may occur immediately above the erosional base. The most common facies of the channel fill association are trough and planar cross-bedded sandstone and ripple crosslaminated sandstone (Fig. 5B, D). The common chaotically bedded sandstone facies is characterised by contorted bedding, soft sediment deformation and a chaotic texture with abundant plant debris and intraformational mudstone clasts in places (Fig. 5E). In the upper part of the channel units, sandstone beds are interbedded with 10-30 $\mathrm{cm}$ thick heterolithic beds that may represent inclined heterolithic strata (Thomas et al. 1987), a variant of epsilon cross-stratification characteristic of tidally influenced fluvial channels (Smith 1987). Mudstone laminae, double mud drapes and flaser bedding, abundant in the sandstone facies of some units, particularly in the upper part of the Bryne Formation, suggest occasional tidal influence in the river system.

Interpretation. Fining-upwards channel units that can be correlated between most wells in the study area (Figs 3, 4), represent laterally extensive channel sandstones deposited by laterally migrating, sinuous rivers. Chaotic bedding may be the result of bank collapse and/or post-depositional collapse of stems and other plant material deposited behind obstacles in the channel. Similar deposits have been described by Alexander \& Gawthorpe (1993; their facies S4) and by Guion et al. (1995) as part of their minor channel facies. The evidence of occasional tidal influence suggests deposition in a coastal plain environment.

\section{Facies association 2: proximal floodplain} (facies 27-29)

Description. The proximal floodplain association consists of interbedded sandstone, siltstone and mudstone (Fig. 5L). The sandstones are generally less than $2 \mathrm{~m}$ thick, but may be amalgamated into units $4-5 \mathrm{~m}$ thick. The sandstone units may fine upwards, coarsen upwards or show no overall grain-size trends. Primary structures include cross-bedding, current ripple lamination, climbing ripple lamination, wave ripple cross-lamination, parallel lamination and chaotic bedding with abundant mudstone and coal clasts. Soft sediment deformation structures are common. Siltstones and mudstones of this association are commonly structureless but may show deformation structures, parallel lamination and lenticular bedding.

Interpretation. The sandstones were deposited in small channels, as crevasse splays, on levees and as small lacustrine deltas. Sandstone units that show bi-directional current ripples, mud flasers and abundant mud laminae were probably influenced by tidal processes during deposition in fluvial channels or distributaries. Siltstones and mudstones are interpreted as waning flow deposits on levees and in small fluvial and crevasse channels or as the passive infill of abandoned channels.

\section{Facies association 3: lake and distal floodplain} (facies 28-30)

Description. Mudstones and siltstones dominate the lake and distal floodplain association (Fig. 5K). Interbedded sandstones are not thicker than a few decimetres. Mudstones and siltstones form units up to $5 \mathrm{~m}$ thick; these are most commonly structureless or show parallel lamination. The parallel lamination is faint and may appear irregular and slightly deformed. Heterolithic units may show lenticular and wavy bedding and current and wave ripples in thin sand beds.

Interpretation. The sediments are interpreted as having been deposited in ponds, shallow lakes and on the distal levee, or represent the passive infill of abandoned channels.

Facies association 4: vegetated floodplain (facies 20, 29, 30)

Description. Sediments with abundant root traces, mottled siltstones and mudstones and coal beds are combined in this facies association. Mottled siltstones and mudstones frequently have a light-coloured 'leached' appearance (Fig. 5G).

Interpretation. The depositional environment was a floodplain where primary deposits were modified by 
vegetation and soil-forming processes. Most soils formed under reducing conditions.

\section{Marginal marine deposits}

Back-barrier and estuarine deposits dominate the upper part of the Bryne Formation and, in the western part of the basin, the Lulu Formation. The marginal marine deposits are separated into five facies associations (5-9), representing estuary channels and bars, flood tidal deltas and washover fans, bay-head deltas and bay-fill, lowenergy estuary and lagoon, and marsh and swamp.

Facies association 5: estuary channel and bar (facies 12-15)

Description. The estuary channel and bar association is represented by 4-10 m thick sandstone-dominated units that may fine upwards, coarsen upwards or show no clear grain-size trend, and as 0.5-4 $\mathrm{m}$ thick, finingupwards, fine- to very fine-grained sandstones and heteroliths. The sandstones show planar and trough cross-bedding with common mudstone laminae (Fig. 6D), and ripple cross-lamination with abundant mudstone flasers (Figs 6C, E, 7). Coal fragments and mudstone clasts occur in some beds, most commonly above erosional surfaces (Fig. 6K, L). Heterolithic strata, 5-20 $\mathrm{cm}$ thick, occur interbedded with the sandstones and may represent beds of inclined heterolithic stratification (Thomas et al. 1987). Interbedded sandstones, mudstones and heteroliths in the fine-grained units show flaser, wavy and lenticular bedding and parallel lamination (Figs 6A, 8B, E). Up to $5 \mathrm{~m}$ thick coarseningupwards units are formed by progressively thicker and coarser grained sandstone beds separated by thin mudstone and siltstone beds (Fig. 9). These sandstone beds may show cross-bedding, ripple cross-lamination, and mudstone flasers and laminae, but may also be structureless with the exception of a few inclined mudstone laminae and mudstone flasers. Intense bioturbation with abundant Teichichnus isp. is common (Fig. 9A, B).

Interpretation. The fining-upwards sandstone units, dominated by cross-bedding and ripple cross-lamination with abundant mudstone laminae, double mud drapes and flaser bedding, are interpreted as estuary point bar deposits (Reineck \& Wunderlich 1968; Visser 1980). Sandstone units that show similar sedimentary structures but lack overall grain-size trends are inter- preted as amalgamated tidal channel sandstones. The finer-grained fining-upwards units represent the passive infill of major channels or the active fill of minor channels. The coarsening-upwards sandstone units represent estuarine channel bars (Fenies \& Tastet 1998) or mouth bar deposits of bay-head deltas.

Facies association 6: flood tidal delta and washover fan (facies 14-16)

Description. The flood tidal delta and washover fan association consists of up to $3 \mathrm{~m}$ thick, generally coarsening-upwards units of sandstones and heteroliths, that may be overlain by fining-upwards units of well-sorted sandstone (Fig. 10F-H). In the coarsening-upwards units, fine-grained heterolithic beds show lenticular and wavy bedding. The most fine-grained sandstones are commonly strongly bioturbated, but some may show flaser bedding and parallel lamination. Coarser grained sandstone facies include trough cross-bedded, parallellaminated and ripple cross-laminated sandstone. The coarser grained sandstones may have erosional surfaces overlain by thin conglomerates. The fining-upwards units are dominated by well-sorted, fine- or very finegrained sandstone showing parallel lamination, lowangle planar cross-bedding, ripple cross-lamination and soft-sediment deformation structures.

Interpretation. The fine-grained heterolithic beds characterised by wavy and lenticular bedding and the coarsening-upwards sandstones with abundant mudstone laminae and flaser bedding, frequently interbedded with lagoonal mudstones, are interpreted as the deposits of flood tidal deltas and tidal sand flats. The coarsening-upwards trend and the association of physical structures correspond well with descriptions of recent flood tidal deltas (e.g. Nichol \& Boyd 1993). The interbedding with lagoonal sediments further supports this interpretation. The well-sorted, erosionally based, finingupwards units that locally overlie flood tidal delta and tidal flat deposits show a close likeness to washover deposits described by Schwartz (1982).

Facies association 7: bay-head delta and bay-fill (facies 4-7, 17, 18, 21)

Description. This association is typified by sandstones and heteroliths arranged in overall coarsening-upwards successions up to $8 \mathrm{~m}$ thick (Fig. 9D-G). The sediments 

A
B
C
E
F
G $\quad H$

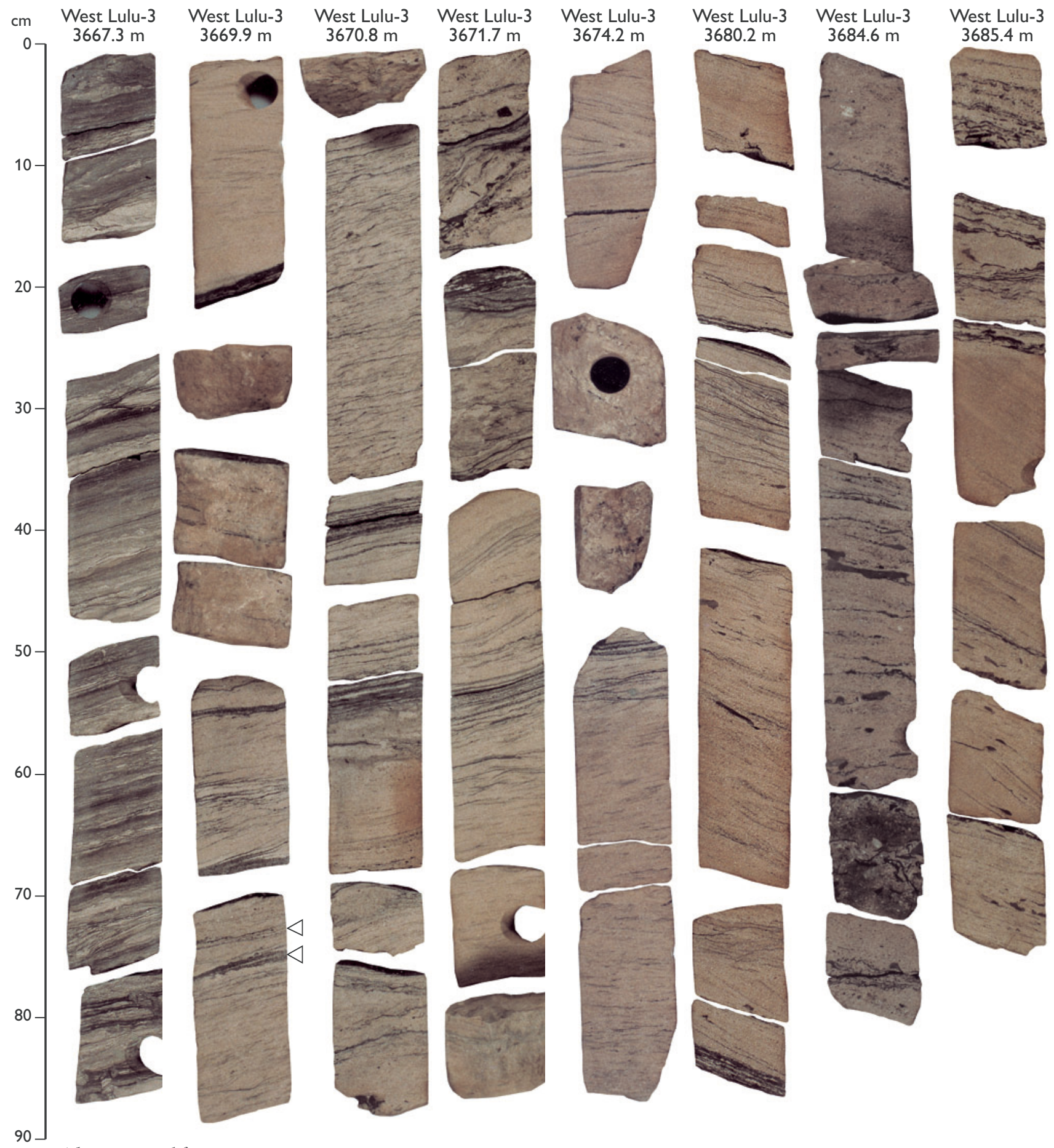

This page and facing page:

Fig. 6. Core photographs of the incised valley-fill (facies associations 5, 8) of the upper Bryne Formation (Cal-1A sequence) in West Lulu-3 (base of succession lower right, top upper left; for location of core sections, see Fig. 16). The erosional base of the incised valley, defining the Cal-1A sequence boundary (SB), is observed in the lowermost core section (L) succeeded by the lower unit of active fluvial or estuary channel fills ( $\mathbf{J}-\mathbf{L}$; facies association 5); this unit is dominated by well-sorted sandstone showing faint cross-bedding or chaotic bedding with abundant coal and mudstone clasts and a basal mudstone clast conglomerate immediately overlying the sequence boundary (L). Lagoonal deposits (I f facies association 8) cap the lower channel unit, represented by burrowed mudstones showing signs of soil-forming processes, and are succeeded by inferred bay-head delta deposits (H). The upper unit of active (B-G) and passive (A) estuary channel fills (facies association 5) is characterised by sandstones with abundant double mud drapes (examples arrowed), flaser lamination $(\mathbf{C})$ and cross-bedding $(\mathbf{F}, \mathbf{H})$. 


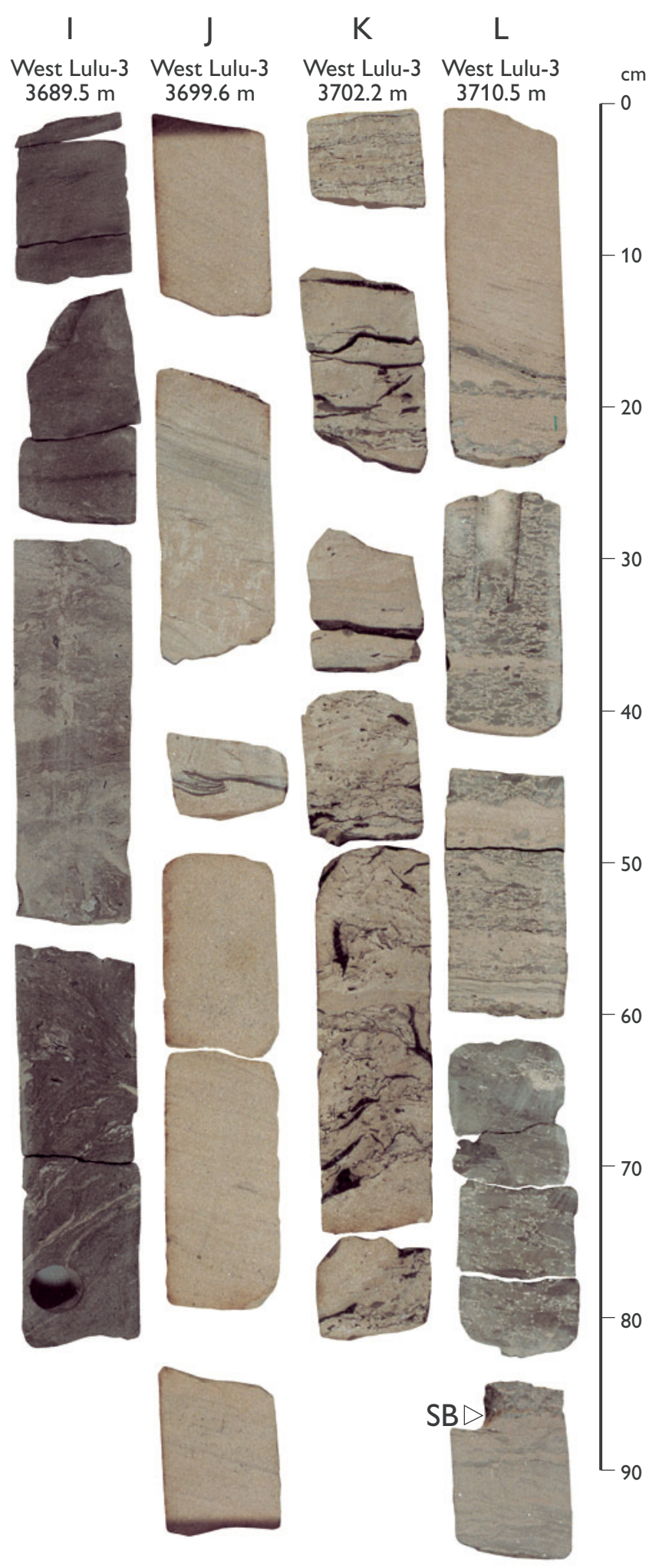

are dominated by current-generated structures, but wave-generated structures also occur. Sandstones with current-generated structures may occur as channel deposits in the upper part of coarsening-upwards successions. Minor units of well-sorted sandstone and heterolith may show low-angle planar cross-bedding, swaley and hummocky cross-stratification, and wave ripple cross-lamination. Levels showing moderate bioturbation with Teichichnus isp. are evident in places. Deposits of this association frequently overlie fine-grained lagoonal deposits.

Interpretation. This association is interpreted to record the progradation of bay-head deltas into estuaries, lagoons, or bays. Depending on the amount of wave influence, the deposits were either slightly modified by small-scale wave activity, or reworked thoroughly by storm wave activity. Deposits may be difficult to distinguish from coarsening-upwards estuary bar deposits of association 5.

Facies association 8: low-energy estuary and lagoon (facies 14, 16, 18, 19)

Description. This facies association is represented by organic-rich mudstones, siltstones and heteroliths, showing parallel lamination, wavy and lenticular bedding, and ripple cross-lamination with mud-flasers, partly obliterated by biogenic activity (Figs 8D, E, 9I). Sedimentary units of this association vary in thickness from a few decimetres to several metres.

Interpretation. The dominance of finer grain sizes suggests deposition in a low-energy environment. The assemblage of sedimentary structures is typical of a tidally influenced environment such as an estuary central basin or a lagoon with extensive tidal flats.

Facies association 9: marsh and swamp (facies 19, 20)

Description. Coals, mudstones and associated rooted heteroliths are grouped in the marsh and swamp association. Mudstones and rooted heteroliths have a dark grey to black appearance, reflecting the high organic content (Fig. 9C, D). Both vitrinite-rich and inertiniterich coals are present.

Interpretation. The vitrinite-rich coals represent deposition in a waterlogged, anoxic mire environment. The 


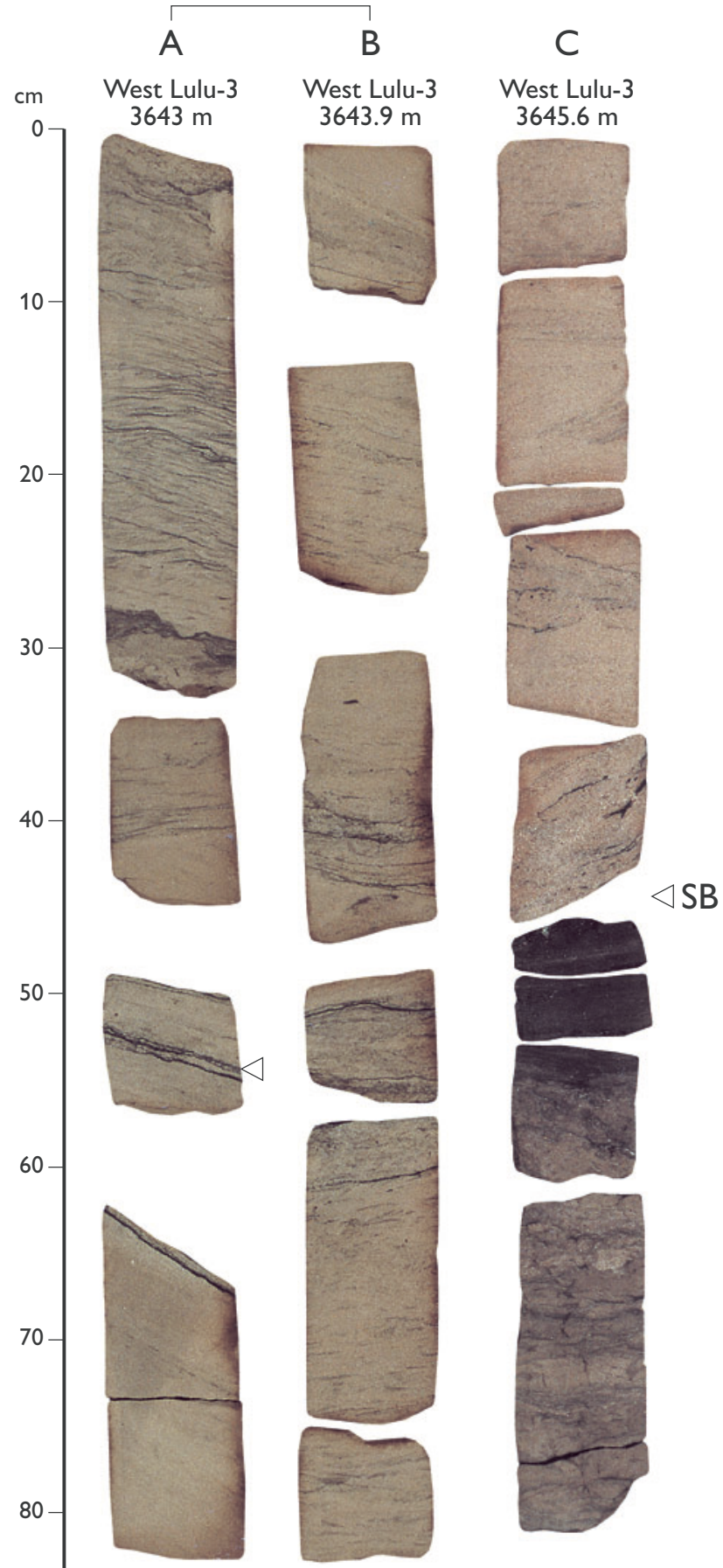

Fig. 7. Core photographs of selected intervals from the middle paralic wedge of the Lulu Formation (Cal-1B sequence) in West Lulu-3 (base lower right, top upper left; for location of core sections, see Fig. 18). This core series illustrates the nature of the Cal-1B sequence boundary $(\mathbf{S B})$ at $3646 \mathrm{~m}(\mathbf{C})$ defined by the erosional base of an estuary channel (facies association 5) cutting into bay/lagoon mudstones (facies association 8). The channel fill sandstones $(\mathbf{A}-\mathbf{C})$ show an overall fining-upwards trend and display cross-bedding, flaser lamination and abundant double mud drapes (example arrowed). inertinite-rich coals represent a somewhat drier environment, with periodically oxic conditions in a swamp or raised bog. Pyrite in some coal beds suggests the occasional influx of marine water. The evidence of marine influxes and the association of the coals and rooted sediments with lagoonal deposits suggest that deposition took place in back-barrier swamps and marshes (Petersen \& Andsbjerg 1996).

\section{Marine deposits}

Marine deposits dominate the Lulu Formation in the central parts of the Søgne Basin, but thin units can be traced into the mainly paralic deposits in the western part of the basin. The marine deposits are separated into three facies associations: offshore, prograding shoreface and beach, and transgressive shelf and shoreface.

\section{Facies association 10: offshore (facies 1, 2, 9)}

Description. The offshore association consists of up to $50 \mathrm{~cm}$ thick units of structureless and laminated mudstone, and $\mathrm{cm}$-scale interbedded, heterolithic mudstone and sandstone. The association frequently forms coarsening-upwards units with structureless mudstone in the basal part overlain by heterolithic mudstone with siltstone and sandstone laminae and beds that show an upwards increase in thickness, grading into the more sandy deposits of the shoreface association (Figs 11A, F, 12I). Laminae may be normally graded, and show parallel lamination and wave and combined flow ripple lamination. The sandstone beds are commonly sharp-based. The sandstone-dominated upper part of coarseningupwards units may grade into hummocky cross-stratified deposits of the prograding shoreface and beach association. Bioturbation in the offshore association varies from weak to intense, but mudstones are commonly completely bioturbated with few remaining physical structures. Anconichnus isp., Palaeophycus isp., Planolites isp. and Teichichnus isp. occur in the sandstone beds.

Interpretation. Mudstones with rare laminae of siltstone or sandstone indicate that deposition took place below storm wave base. The thorough bioturbation of the mudstones suggests they were deposited on a shelf with oxic bottom conditions. A higher content of siltstone and sandstone laminae suggests the occasional 
Fig. 8. Core photographs of the incised valley-fill of the upper Bryne Formation (Cal-1A sequence). A: Erosional surface (SB) marking the base of the incised valley (Cal-1A SB) cuts into mottled floodplain mudstones (Bat-1B sequence; facies association 3) and is overlain by estuary channel sandstones (facies association 5) showing cross-bedding and mudstone clasts. Lulita-1; for location of core section, see Fig. 17. B-F: Estuary channel sandstones and heterolithic beds in Amalie-1 (base lower right, top upper left; for location of core sections, see Fig. 17). The largescale cross-bedded sandstones $(\mathbf{C}, \mathbf{F})$ with abundant mud drapes and mudstone clasts represent the lower fill of estuary channels (facies association 5). The intervening heterolithic beds (B-E) may represent tidal flats (facies association 8) or fluctuating energy levels in the upper fill of estuary channels (facies association 5).
A

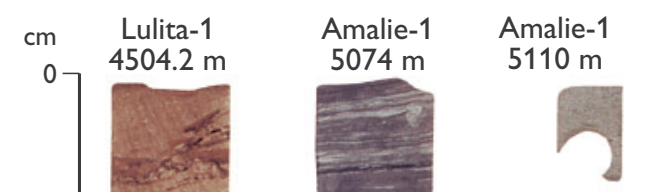

$10-$

20

50

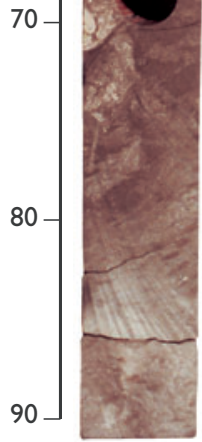

$60-$

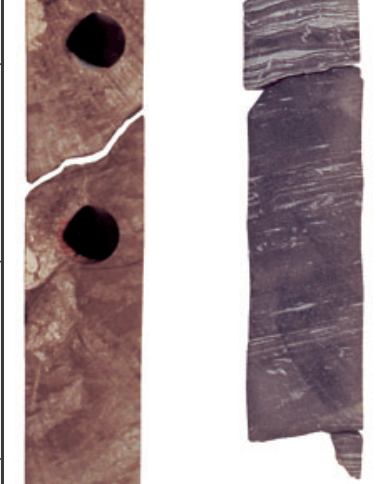

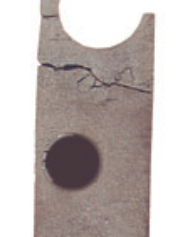

$\triangleleft \mathrm{SB}$

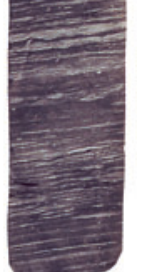

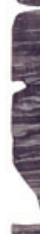

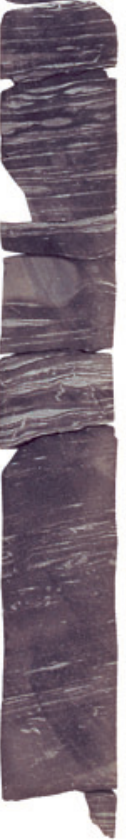

B

Amalie-1
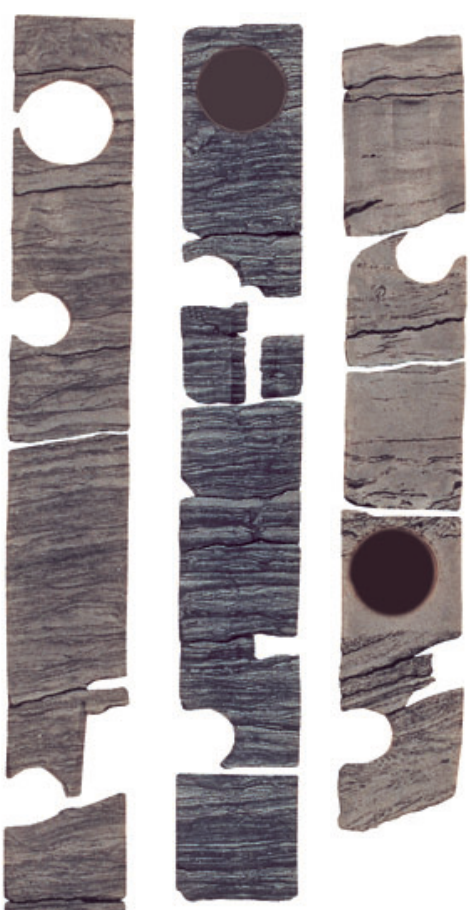

Amalie-1 Amalie-1

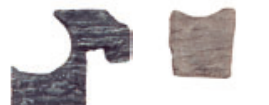
$5112 \mathrm{~m} \quad 5118 \mathrm{~m}$

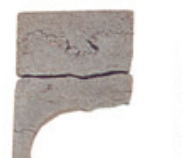
$5111 \mathrm{~m}$
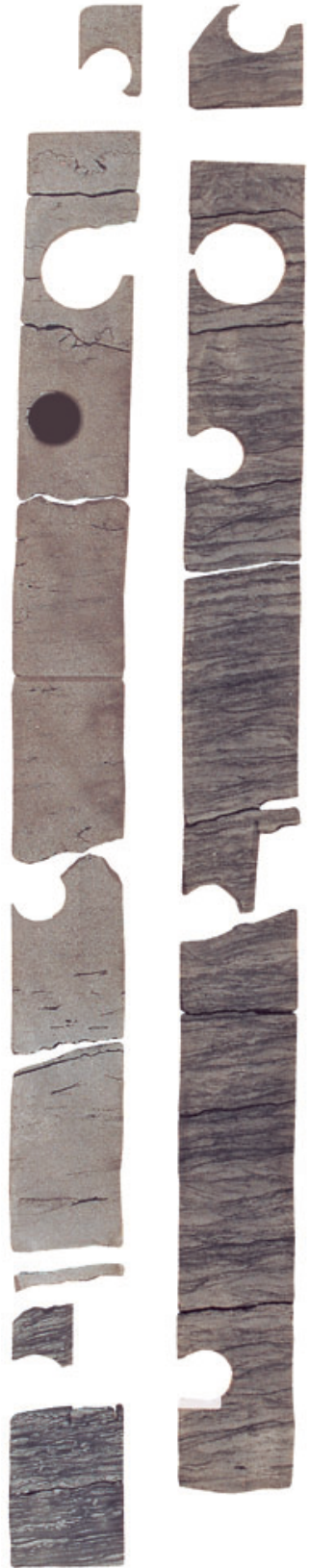
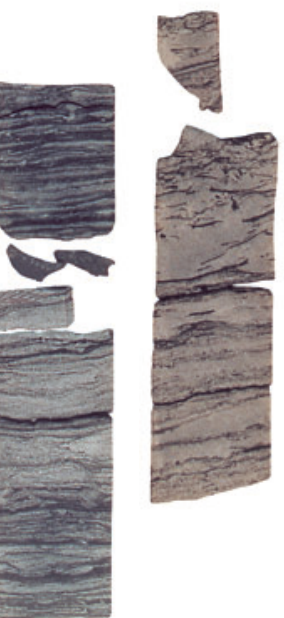


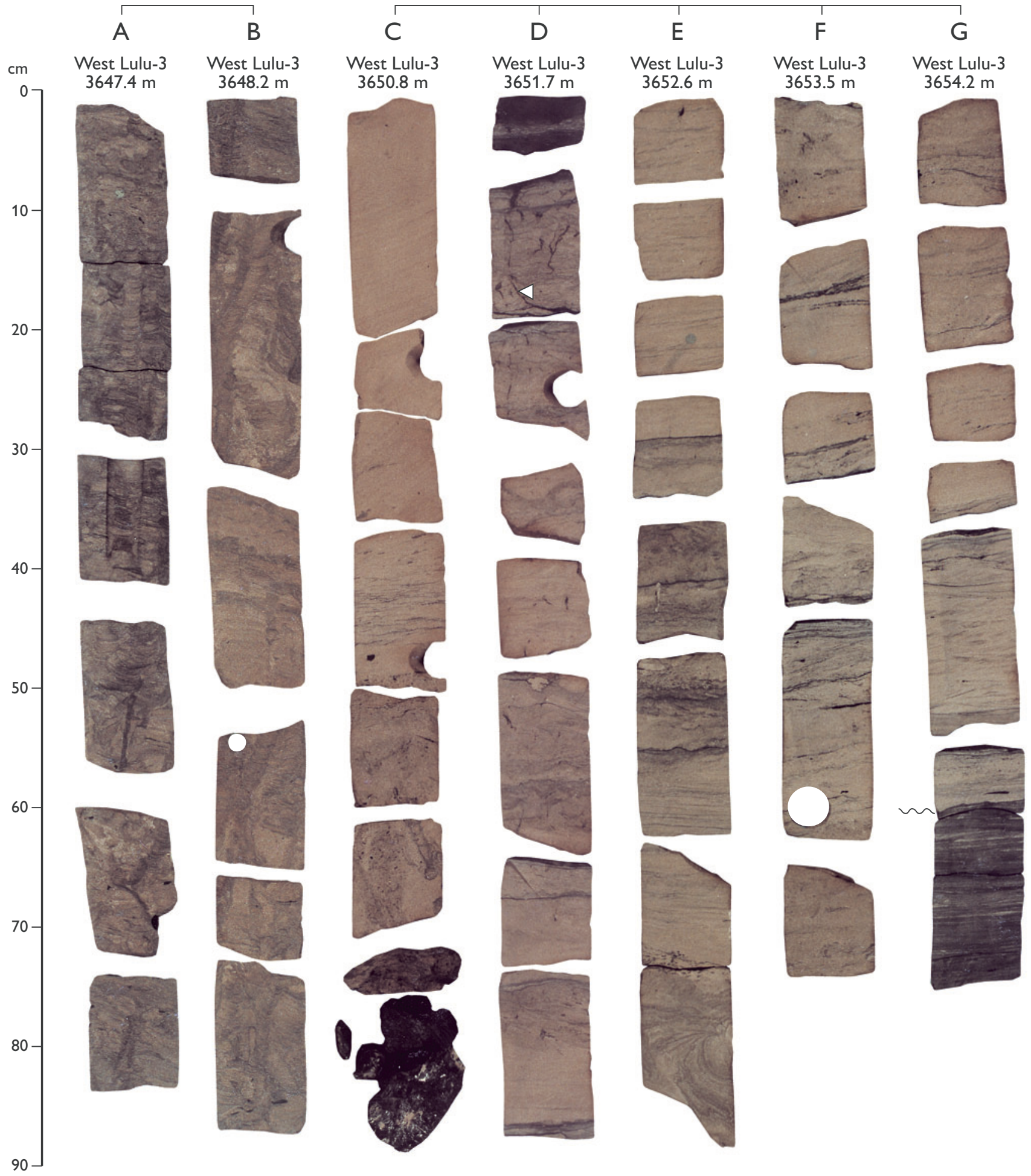

Fig. 9. Core photographs of back-barrier deposits of the lower paralic wedge in the Lulu Formation (Cal-1A sequence) in West Lulu-3 (base lower right, top upper left; for location of core sections, see Fig. 18). The selected core sections illustrate lagoonal mudstones with sandstone interbeds (facies association 8) at the base (G-I), erosively overlain (wavy line, 3654.8 $\mathrm{m}$ ) by a broadly coarsening-upwards sandstone unit $(\mathbf{C}-\mathbf{G})$ - climbing ripple cross-laminated sandstones being succeeded by cross-bedded sandstones with double mud drapes and rare burrows. This coarsening-upwards sandstone unit (facies association 5) shows rootlets (arrowed) towards the top and is capped by a coal bed (C, D); it is succeeded by thoroughly bioturbated sandstones (A, B; mainly Teichichnus isp.) representing the upper part of an estuary sand bar that immediately underlies bay/lagoonal deposits spanning the MFS of the Cal-1A sequence (not shown in core, see Fig. 18). 


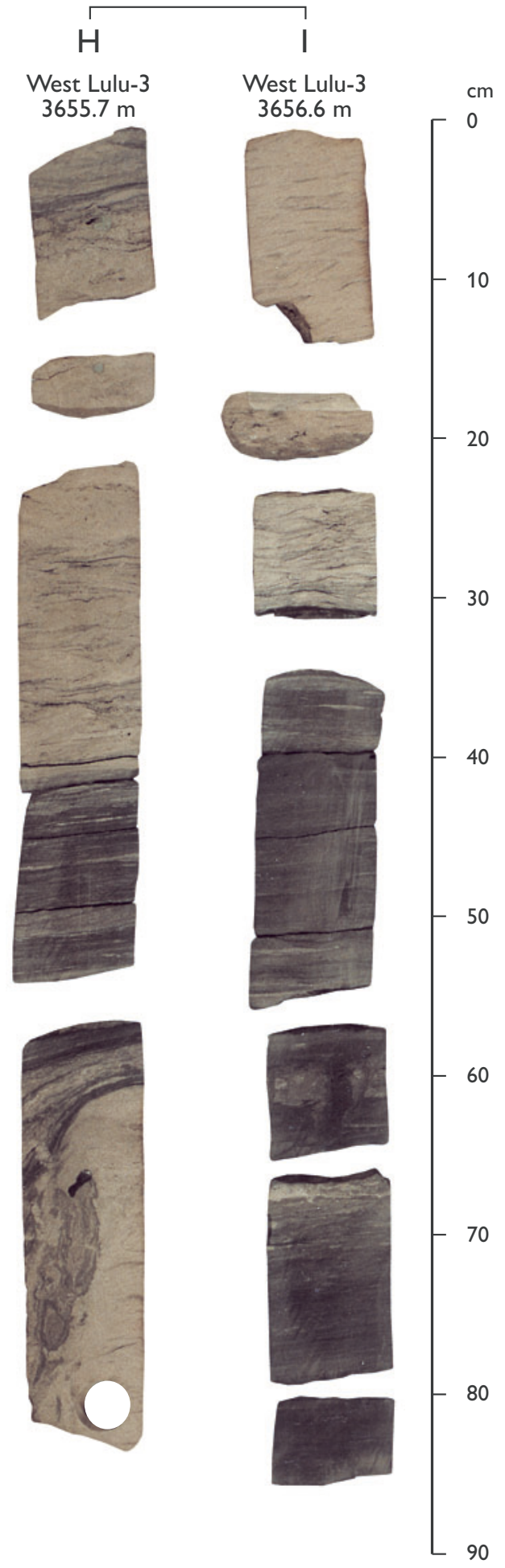

influence of oscillatory currents near storm wave base. Sharp-based sandstone laminae are interpreted as storm-sand deposits, and their finer-grained interbeds represent fair-weather sediments and suspension fall-out after storms. Deposition took place between storm wave base and fair-weather wave base.

Facies association 11: prograding shoreface and beach (facies 3-8)

Description. The prograding shoreface and beach association is represented by up to $12 \mathrm{~m}$ thick coarsening-upwards successions of sandstone and subordinate siltstone. The coarsening-upwards successions consist of very fine-grained, hummocky cross-stratified (HCS) and swaley cross-stratified (SCS) sandstones with siltstone interbeds in the lower part, overlain by low angle cross-bedded fine- to medium-grained sandstones and trough and planar crossbedded fine- to coarse-grained sandstones (Figs 11B-E, 12). Parallellaminated, low-angle cross-bedded and massive fine- to coarse-grained sandstones and pebble conglomerates may occur at the top of the successions. The HCS- and SCS-dominated sandstones occur as sharp-based, laminated beds ranging between a few decimetres and a few metres in thickness, separated by centimetres to decimetres thick siltstone beds. Lamination may be gently undulating, and typically intersect and truncate at low angles. Individual hummocky crossstratified units may grade into wave-rippled heterolithic siltstone and sandstone. SCS sandstones typically occur as thicker amalgamated units that lack the heterolithic sub-units and the silty interbeds. The cross-bedded sandstones occur in poorly defined sets, usually a few decimetres thick.

Interpretation. The coarsening-upwards successions are interpreted as the deposits of prograding shelf, shoreface and shoreline systems. Minor, 2-4 m thick, coarsening-upwards units of typical shoreface deposits may represent wave-influenced mouth bars or ebb tidal deltas. The HCS-dominated units, commonly lowermost in the successions, were deposited by storm wave activity below fair-weather wave base in the offshore transition zone. The SCS deposits represent more continuous wave activity on the lower shoreface, whereas the cross-bedded sandstones of the upper part of the succession represent migrating dunes on the upper shoreface. The horizontally laminated and low-angle cross-bedded sandstones uppermost in the successions represent foreshore, beach and strandplain deposits.

Facies association 12: transgressive shelf and shoreface (facies 9, 10)

Description. Deposits of the transgressive shelf and shoreface association consist of poorly sorted, bioturbated muddy sandstones, sandy siltstones and mudstones and heteroliths, poorly sorted pebbly 

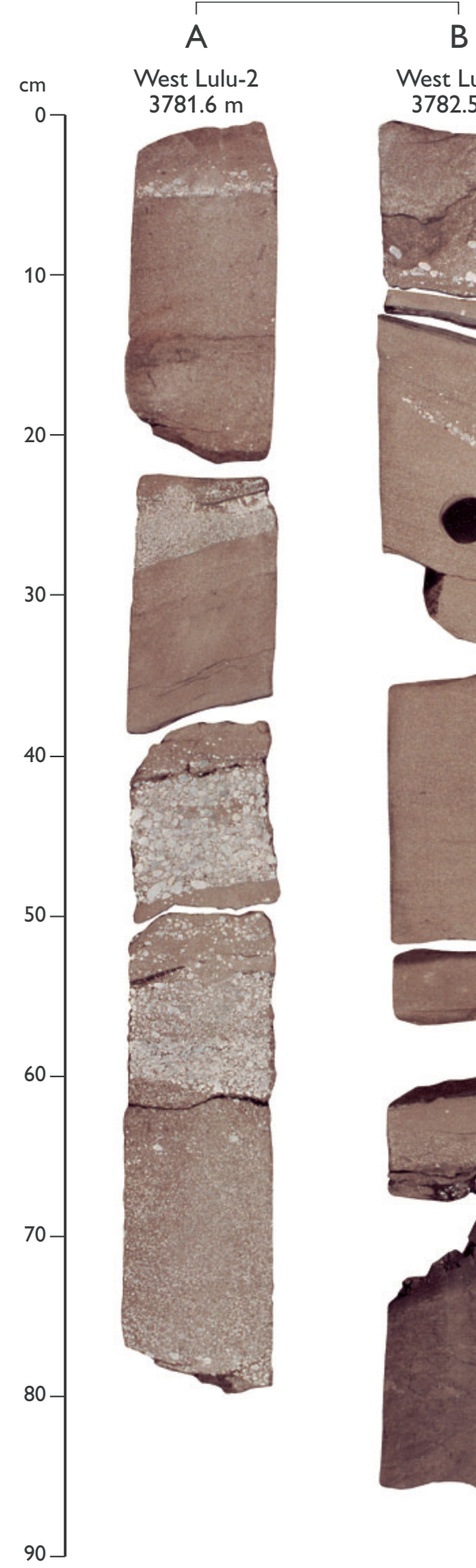

C
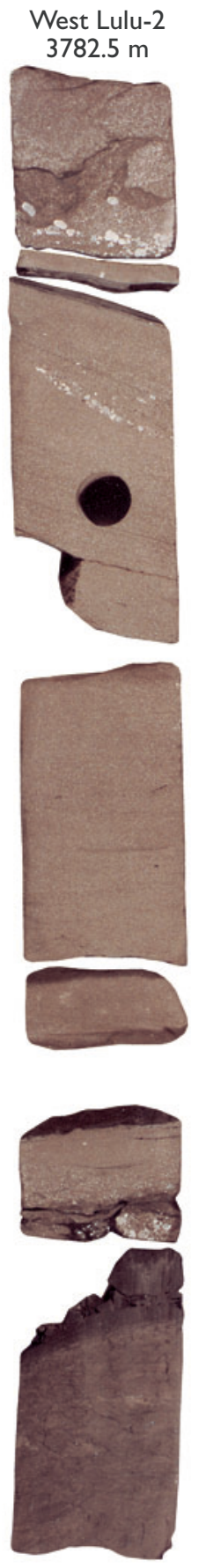

West Lulu-2

$3790 \mathrm{~m}$
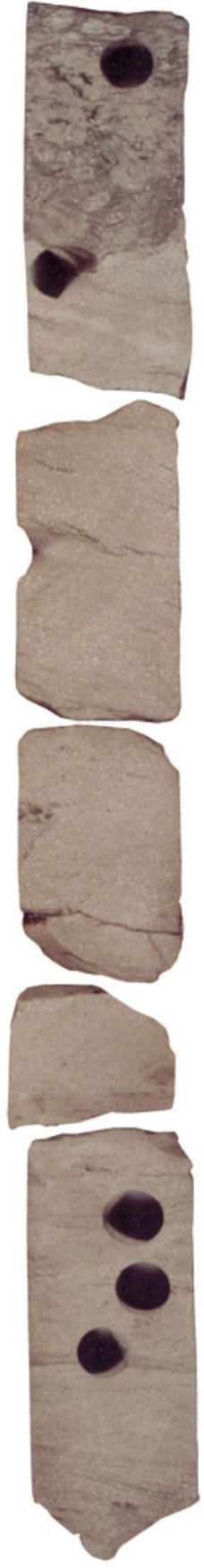

D

West Lulu-2
$3798.4 \mathrm{~m}$
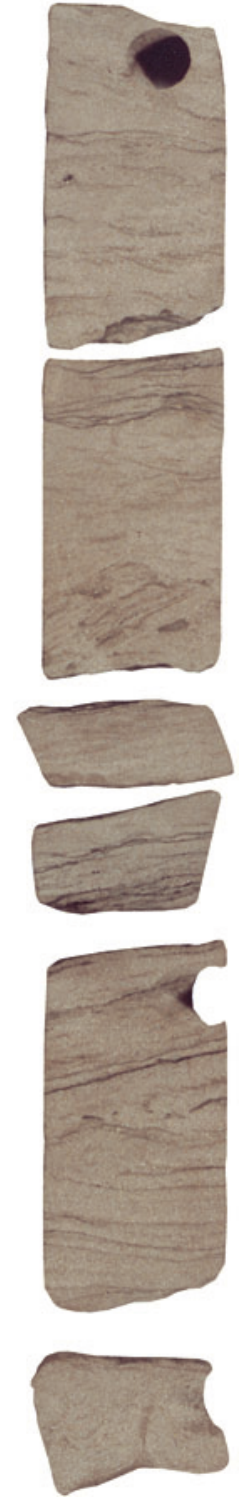

$\triangleleft \mathrm{SB}$

West Lulu-2

$3799.2 \mathrm{~m}$
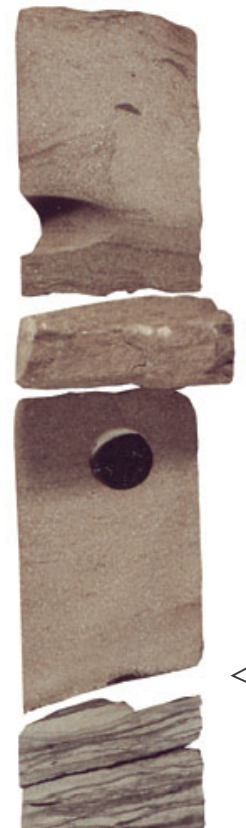


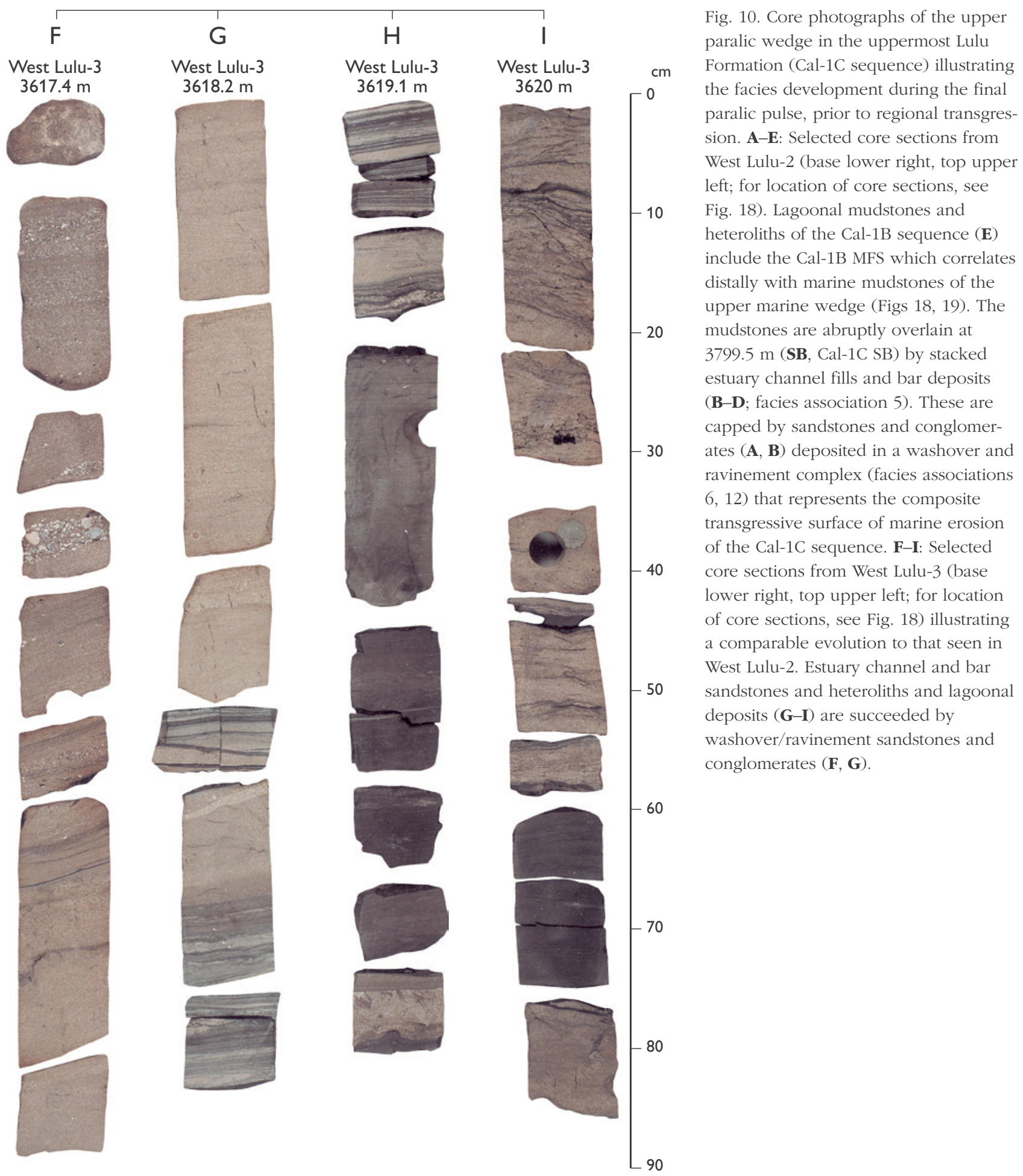




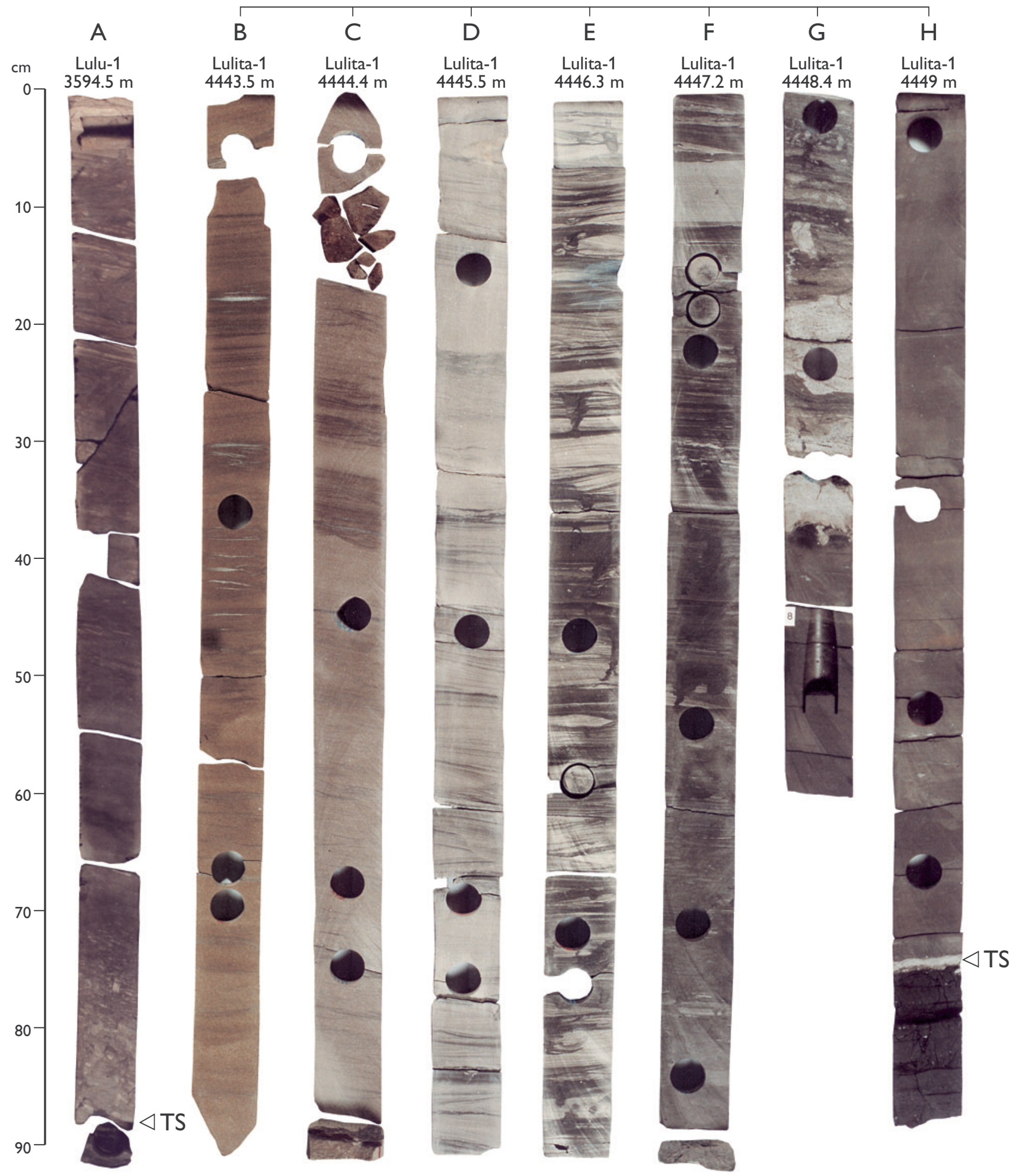

Fig. 11. Core photographs of marine shelf and shoreface deposits (facies associations 10, 11) from the lower marine wedge of the Lulu Formation (Cal-1A sequence) in the Lulu-1 and Lulita-1 wells, close to the basin axis. A: Core section from Lulu-1 (for location, see Fig. 19) illustrating the transgressive surface (TS) overlain by $10-20 \mathrm{~cm}$ of thoroughly bioturbated muddy sandstone; this is succeeded by shelf mudstones (facies association 10), including the maximum flooding surface within the interval 3595.2-3594.9 m, grading up into mud-rich heteroliths at the base of a coarsening-upwards prograding shoreface succession (not illustrated here, see Fig. 19). B-H: Selected core sections from Lulita-1 (base lower right, top upper left; for location of core sections, see Fig. 19) illustrating a coarsening-upwards prograding shoreface succession (facies association 11). The transgressive surface (TS) at the base (H), overlying lagoonal mudstones, is draped by a thin $(1 \mathrm{~cm})$ sandstone, passing abruptly up into structureless shelf mudstones. Upwards, the mudstones are interbedded with discrete storm sandstone beds (G) and grade up via heterolithic facies showing HCS (E, F) to sandstones with HCS, SCS and cross-bedding (B-D). The maximum flooding surface occurs within the interval 4448-4447.7 m. 
sandstones, and conglomerates (Fig. 10A, F). The deposits are characterised by intense burrowing and a diverse ichnofauna (Fig. 11A).

Interpretation. These sediments were deposited in a shoreface or shallow shelf environment during a transgression. Physical structures reflecting the high energy level on the upper shoreface were partly or completely obliterated by burrowing organisms under more tranquil conditions.

\section{Architecture, depositional environments and sequence stratigraphy}

A regional unconformity subdivides the Bryne Formation into two separate parts described here as the lower and the upper Bryne Formation (Figs 3, 4); evidence supporting the recognition of this unconformity is presented below. The architecture and depositional environments of the lower and upper Bryne Formation and the Lulu Formation are described here, together with a sequence stratigraphic analysis of these units.

\section{Lower Bryne Formation}

\section{Depositional architecture and environments}

The lower Bryne Formation consists of floodplain deposits separated by several storeys of channel sandstones. The four most distinct channel units are referred to as units A, B1, B2 and C (Figs 3, 4). These channel sandstones can be identified in most wells and probably form laterally continuous sandstone sheets. The lowermost strata of the Bryne Formation are either finegrained floodplain deposits located below the lowermost channel sandstone (unit A; West Lulu-1, West Lulu-4) or channel sandstone unit A resting directly and unconformably on Triassic or Permian deposits (West Lulu-2, West Lulu-3; Fig. 4).

In some wells, channel sandstone unit A is a $10-30 \mathrm{~m}$ thick multi-storey sandstone section of stacked, finingupwards, 5-15 $\mathrm{m}$ thick sandstone units separated by mudstone beds, 1-2 m thick. In other wells, it is a single storey sandstone, 1-2 m thick (Fig. 4). The thickness variations may be related to pre-Middle Jurassic topographic relief. Cores are not available from this unit.

The two channel sandstone units B1 and B2 are closely associated, usually with the base of $\mathrm{B} 2$ lying $c .10 \mathrm{~m}$ above the top of B1 (Fig. 4). In many wells, the gamma-ray logs of the combined unit B1-B2 show a characteristic fining-upwards - coarsening-upwards - fining-upwards pattern (e.g. Amalie-1, 5280-5260 m; West Lulu-4, 3768-3740 m; Fig. 4). Cores are available from unit B2 in the West Lulu-3 well (Figs 5, 13).

Channel sandstone unit $\mathrm{C}$ is a fining-upwards $10 \mathrm{~m}$ thick channel unit recognised in most wells and cored in West Lulu-1, West Lulu-2 and West Lulu-4 (Figs 5, 14). Unit $\mathrm{C}$ consists of cross-bedded sandstone with abundant wood fragments and mud clasts (Fig. 5H-K) and an increasing number of clay drapes up-section, some of which are paired. The upper part of the channel unit is heterolithic with decimetre thick sand/mud couplets in West Lulu-2 and abundant clay drapes and mud flasers in West Lulu-1.

The channel units show features that are characteristic of the deposits of sinuous channels. Most of the channel bodies have fining-upwards grain-size profiles above erosional bases, they appear to be laterally continuous and regularly spaced mudstone laminae or beds may represent mud drapes on low-angle accretion surfaces (Fig. 14). In addition to these features, the cores from sand sheets B2 and C show trough and planar crossbedding, ripple cross-lamination and abundant deformation structures; the basal beds contain intraformational mudstone clasts and wood fragments. The presence of double mud drapes, abundant flaser bedding and decimetre thick sand/mud couplets in channel unit C may indicate that the channel system was influenced by tidal processes. The channel sands were deposited in laterally migrating, sinuous river channels on a coastal plain. The evidence of tidal influence in unit $\mathrm{C}$ suggests it may have been connected downstream to an estuary. The upwards increase in tidal influence in this succession may indicate an overall rise in relative sea level.

The laterally continuous channel sandstones are separated by up to $50 \mathrm{~m}$ thick successions of interbedded mudstone and sandstone (Fig. 4). The fining-upwards segments of these successions may appear as an upwards continuation of underlying fining-upwards channel deposits. A mudstone that varies in thickness from a few decimetres to three metres is present at the turnaround point between the fining-upwards and the coarseningupwards segments of the succession (Fig. 4). The sandstones form $1-4 \mathrm{~m}$ thick units that may fine upwards or show no clear grain-size trends (Figs 13-15; Fig. 15 faces page 332). The sandstones of both the finingupwards and coarsening- upwards segments of the succession show a diverse assemblage of sedimentary structures including climbing ripple lamination, plane 


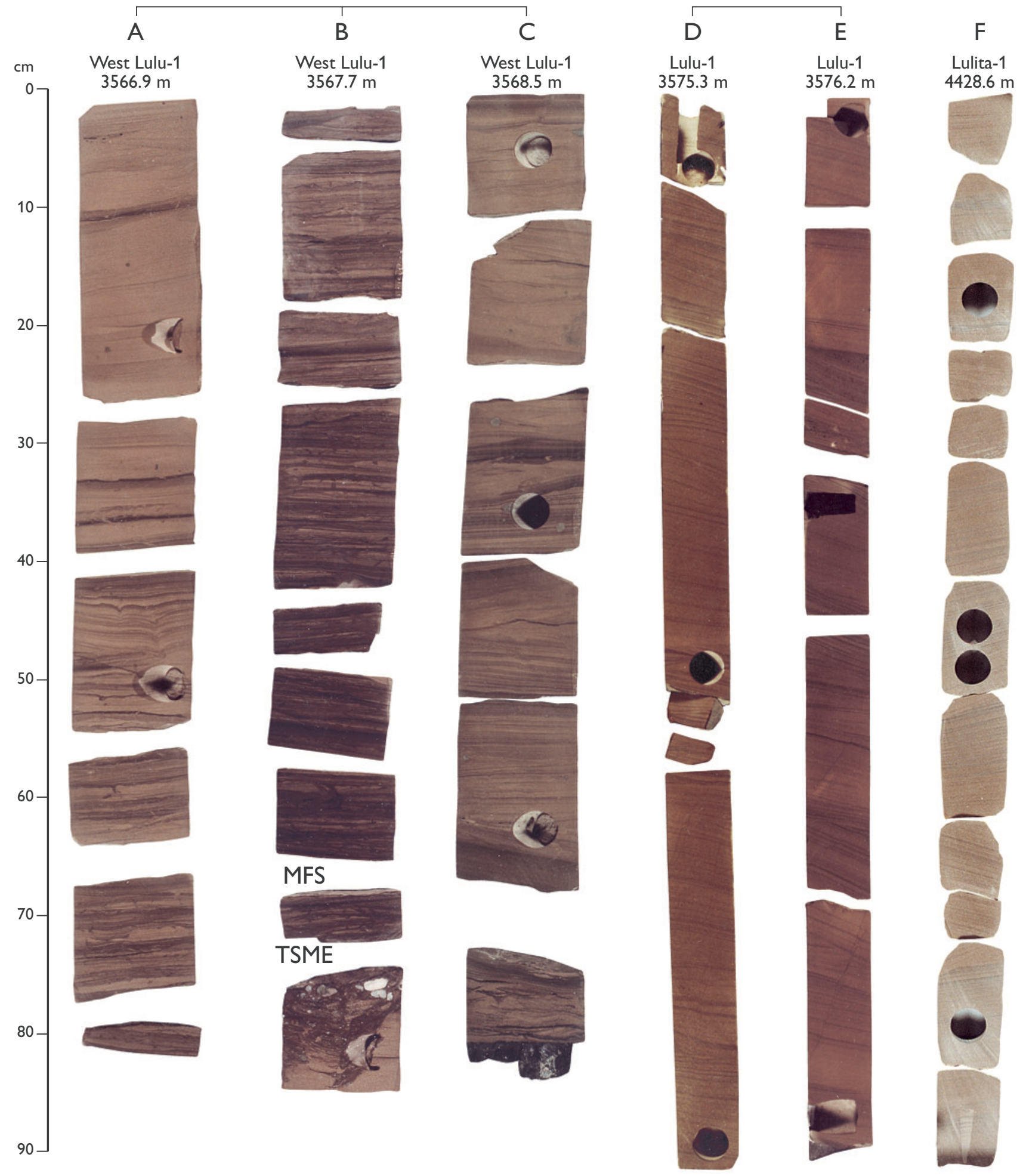




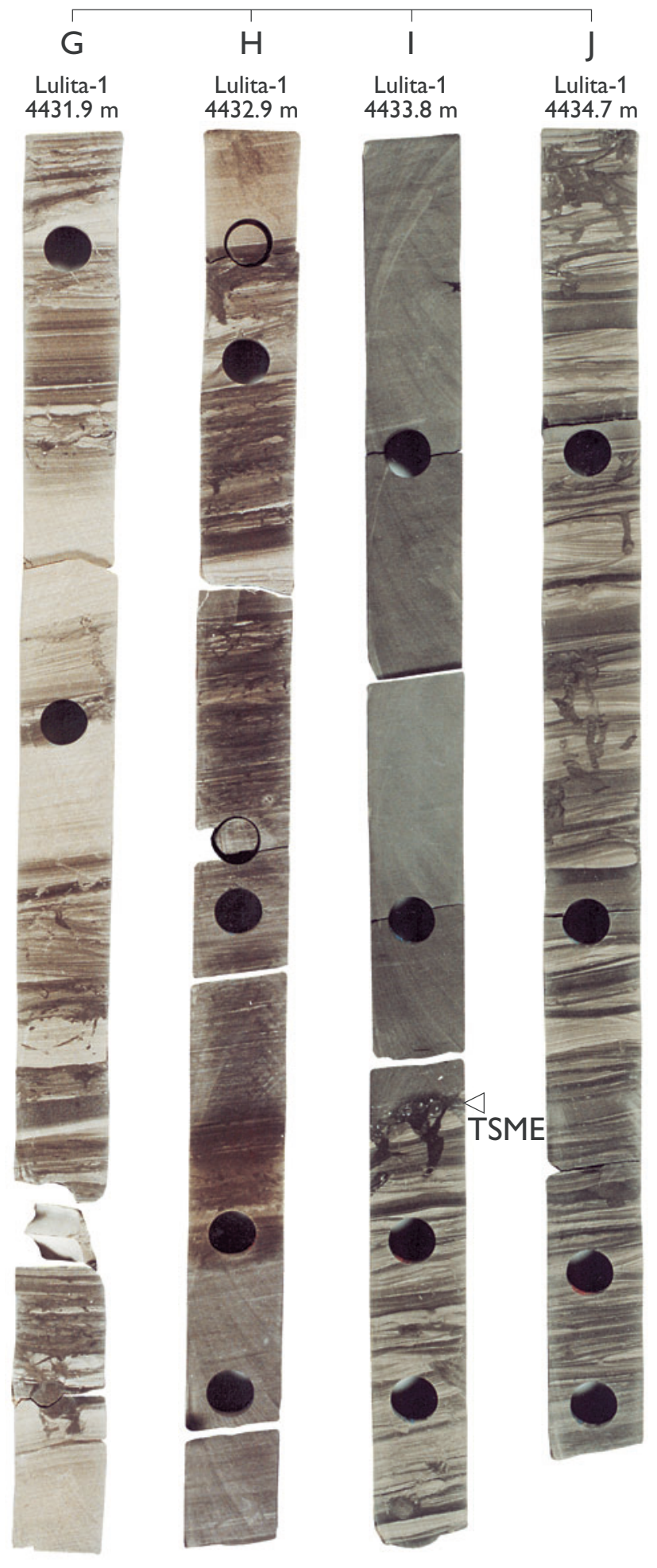

Fig. 12. Core photographs of marine shelf and shoreface deposits (facies associations 10-12) from the upper marine wedge of the Lulu Formation (Cal-1B sequence).

A-C: Sandstones and heteroliths from wave-influenced mouth bar or protected shoreface deposits in West Lulu-1 (base lower right, top upper left; for location of core sections, see Fig. 18). Note the pebble lag (facies association 12) at the transgressive surface of marine erosion (TSME), and the maximum flooding surface (MFS), c. $10 \mathrm{~cm}$ higher in the section.

$\mathbf{D}, \mathbf{E}$ : Wave-dominated shoreface deposits (facies association 11) in the Lulu-1 well showing coarsening-upwards sandstones dominated by SCS (base lower right, top upper left; for location of core sections, see Fig. 19).

F-J: Selected cores from a succession of stacked shoreface parasequences (facies associations 10,11) in Lulita-1 (base lower right, top upper left; for location of core sections, see Fig. 19). The lower parasequence of heterolithic sandstones $(\mathbf{I}, \mathbf{J})$ showing HCS and wave ripple cross-lamination is truncated by a transgressive surface of marine erosion (TSME) and overlain by shelf mudstones (I) that include the maximum flooding surface within the interval 4434.4-4434.1 $\mathrm{m}$. The mudstones grade up into the next prograding shoreface parasequence, comprising heteroliths and sandstones showing HCS and SCS $(\mathbf{G}, \mathbf{H})$. Core section $\mathbf{F}$ illustrates the well-sorted swaley cross-stratified sandstones that typically cap the shoreface parasequences. 


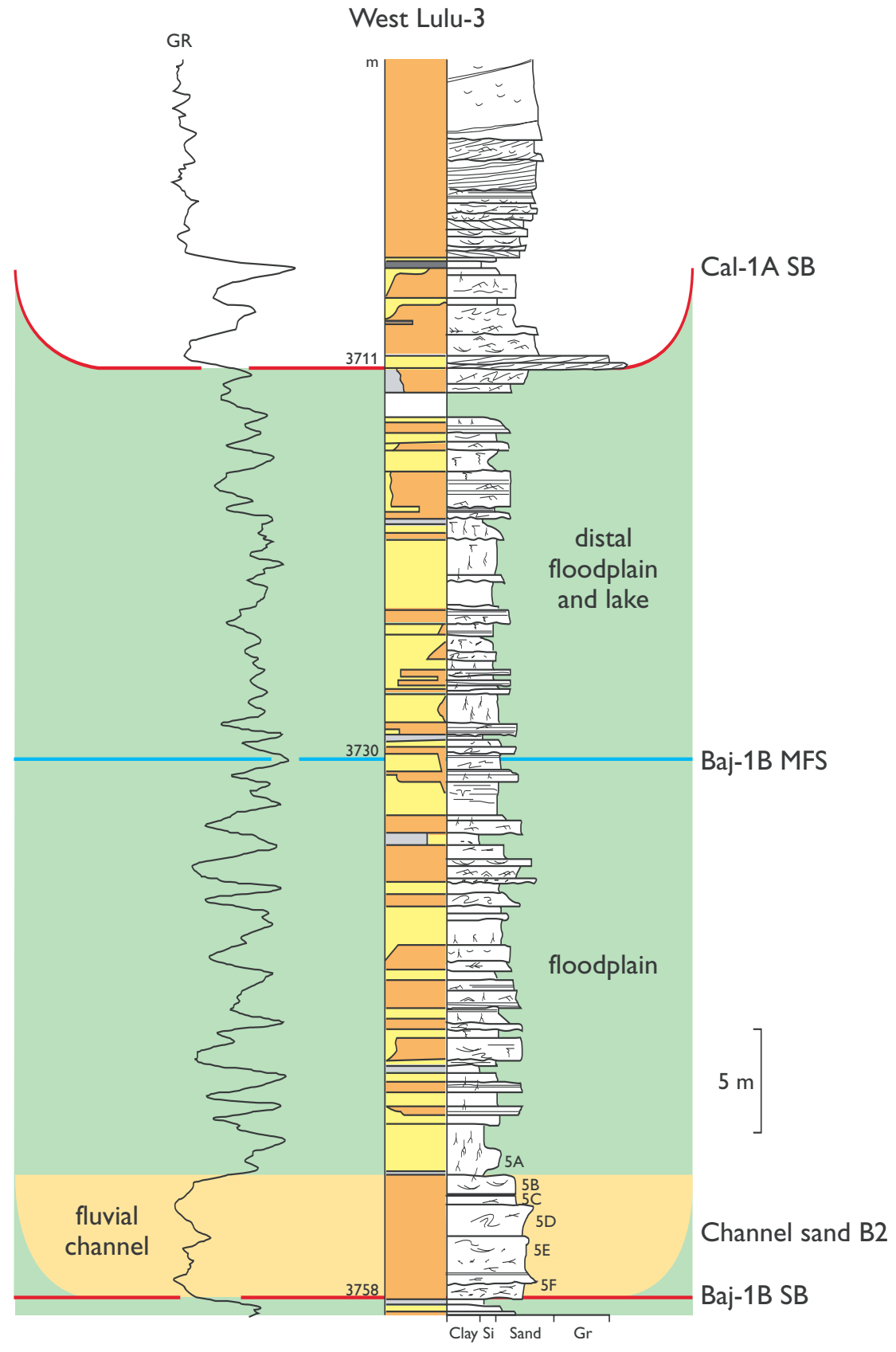

Fig. 13. Sedimentological core log and gamma-ray (GR) log of sequence Baj-1B in West Lulu-3. The channel sand B2 is located above the Baj-1B SB in the basal part of the illustrated section. The Baj-1B MFS is placed in the middle of the thick floodplain/lake succession above the channel sand B2. The positions of cores illustrated with photographs here are indicated on the sedimentological logs (e.g. $\mathbf{5 A}$ indicates core photograph in Fig. 5A). Depths of important surfaces, facies changes or core breaks are indicated (in metres below reference level). The accompanying sedimentological legend is also applicable to Figs 14-19.
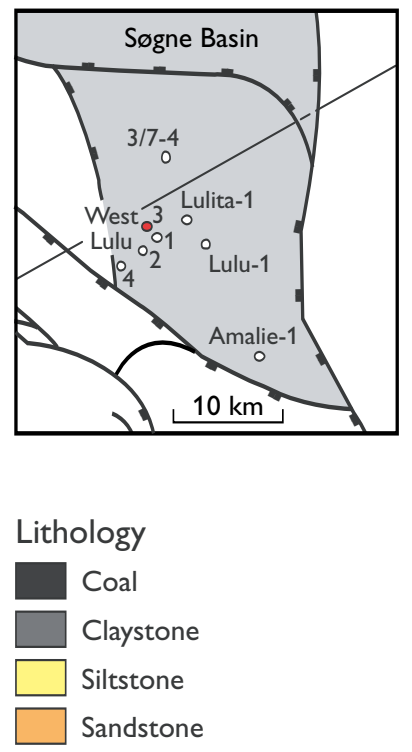

Depositional environments

Floodplain

Fluvial channels

\section{Key surfaces}

- Sequence boundary (SB)

— Maximum flooding surface (MFS)

Sedimentary/biogenic structures

Erosional surface

产 Parallel bedding/lamination

IIIII Planar cross-bedding

Trough cross-bedding

Low-angle cross-bedding

- Hummocky cross-stratification

Cross-lamination and climbing ripples

\# Bimodal current-ripple lamination

त太 Wave ripples

^ Flaser bedding

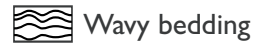

\begin{tabular}{|c|c|}
\hline$\infty$ & Lenticular and silt-streaked bedding \\
\hline & Mudstone/coal chips \\
\hline$\Omega^{1}$ & Disturbed bedding \\
\hline & Load structures \\
\hline & Water escape structures \\
\hline V & Synaeresis cracks \\
\hline 5 & Bioturbation \\
\hline$\lambda \lambda$ & Rootlets \\
\hline
\end{tabular}


lamination and slump structures, as well as dispersed rip-up mud clasts, root traces and pedogenic mottling (Fig. 5). The deposits are interpreted as levees, consisting of proximal crevasse splays, small channel fills and small deltas, and more distally as lake, swamp and distal crevasse splay deposits; these sediments are referred to the proximal floodplain association, the lake and distal floodplain association and the vegetated floodplain association. Palynological evidence for marine conditions is scarce in these deposits in the Søgne Basin, although rare marine palynomorphs have been found in the succession separating units B2 and C in West Lulu3 indicating that short-lived marine incursions may have occurred.

The succession between channel unit $\mathrm{C}$ and the Cal-1A SB includes both channel sandstones and floodplain deposits (Fig. 4). The succession attains a thickness of $30 \mathrm{~m}$ in Lulita-1, $50 \mathrm{~m}$ in West Lulu-1, $60 \mathrm{~m}$ in Amalie-1 and $65 \mathrm{~m}$ in 3/7-4. Channel sandstones dominate the succession in the West Lulu-1 and 3/7-4 wells. Cross-bedding is less prominent in the channel sandstones of this succession than in units B2 and C. Mudstone clasts and soft-sediment deformation are common, and current ripple and climbing ripple lamination occur in the upper part of channel units (Fig. 5). Root horizons and pedogenic mottling are abundant in the more fine-grained deposits. Fine-grained sediments dominate the succession in the wells closest to the basin axis. In Lulita-1, a $14 \mathrm{~m}$ thick section of coals and organic-rich mudstones overlie the channel sandstones at the base of the succession (Fig. 15). Most distinctive among the fine-grained deposits is a $50 \mathrm{~m}$ succession of mudstones with thin sandstone and siltstone interbeds in Amalie-1. Due to the lack of dinoflagellate cysts from this unit, it is interpreted to represent a lacustrine environment. Sandy and silty interbeds represent lacustrine delta and lacustrine delta plain/distal floodplain deposits. The $14 \mathrm{~m}$ thick coal-bearing section in Lulita-1 represents a swamp environment.

A relatively deep lake existed in the southern and central part of the basin simultaneously with an active floodplain along the western margin. At least some of the channel sandstones in West Lulu-1 and 3/7-4 may represent distributaries of lacustrine deltas (Fig. 15). Although there is no palynological evidence for marine conditions, short-lived marine incursions of the coastal plain may occasionally have turned the lake into a brackish water lagoon or bay.

\section{Sequence stratigraphy}

\section{Key surfaces}

The basinwide extent of both the erosional bases of major channel sandstones and the mudstones that are located at the turnaround points of the fining-upwards - coarsening-upwards successions between the sandstones, suggests that they are not simply the result of autocyclic facies shifts but more likely resulted from regional base-level changes. Both channel base diastems and turnaround points can thus be seen as sequence stratigraphic key surfaces.

Sequence boundaries in the lower Bryne Formation are defined by channel base diastems of the major, laterally extensive channel sandstones (Fig. 4). Although key surfaces such as the maximum flooding surface (MFS) and the transgressive surface (TS) do not extend landwards beyond the bay-line (Posamentier \& Vail 1988), non-marine equivalents to the MFS are assumed to occur within widespread lacustrine and floodplain deposits. The presence of an equivalent to the MFS in this setting results from the influence of relative sea-level fluctuations on the groundwater level in the lower coastal plain. Surfaces that separate units of amalgamated, laterally extensive channel sandstones from significantly more fine-grained floodplain successions may represent a landwards expression of marine flooding events. In addition, growth of coal-forming peat due to a rise in the groundwater table and associated generation of new accommodation, may be the landwards expression of a marine flooding surface (Petersen \& Andsbjerg 1996).

\section{Systems tracts}

In the lower Bryne Formation, the fluvial sand sheets fine upwards or occur as amalgamated sandstones without a visible grain-size trend (e.g. Baj-1A in 3/7-4). The laterally continuous fluvial sand sheets typically found above the sequence boundaries in the alluvial plain deposits represent the LST and the lower part of the TST (Figs 3, 4). They are comparable to the low accommodation systems tract of Dreyer et al. (1995), and the amalgamated fluvial sand sheet of Shanley \& McCabe (1991, 1993, 1994) and Olsen et al. (1995).

Channel development was probably initiated during falling or static base level, but the lateral migration of channels during early base-level rise may have caused erosion of a significant proportion of the lowstand deposits. Thus, the channel sandstones may largely represent the lower part of the TST. Extensive reworking of the floodplain by lateral channel migration during 


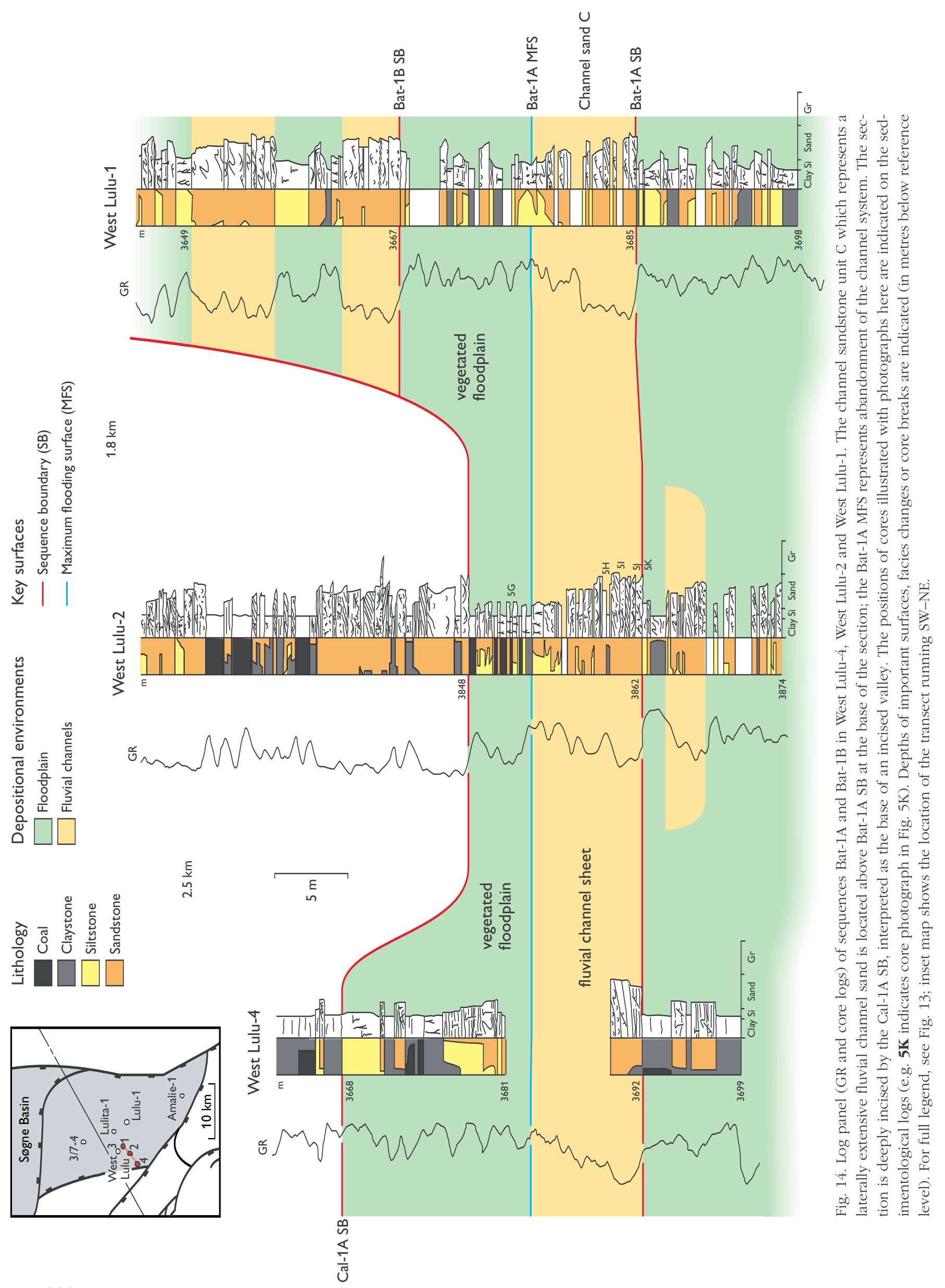


periods of lowstand and early base-level rise may have effectively prevented floodplain aggradation (Wright \& Marriott 1993).

The overbank-dominated deposits between the top of the channel sandstone sheets and the MFS, constituting the upper part of the TST, are organised into a fining-upwards succession with a gradually decreasing sand/shale ratio. Mudstones of mainly lacustrine origin become increasingly common upwards. Soil profiles and root horizons are common (Fig. 5G, H, L).

The overall fining-upwards trend and accompanying decreasing sandstone/mudstone ratio are interpreted to reflect a sea-level rise that caused a rising watertable and wetter conditions on the coastal plain. The increasing rate of creation of accommodation during rising base level favoured high levels of storage of floodplain sediments and more isolated channel bodies (Shanley \& McCabe 1993; Wright \& Marriott 1993). The transgressive floodplain deposits are equivalent to the heterolithic unit with isolated fluvial sandbodies of Olsen et al. (1995) and the lower part of the high accommodation systems tract of Dreyer et al. (1995).

The floodplain highstand deposits are separated from the floodplain transgressive deposits by a MFS. The MFS is picked in a mudstone bed that is typically organicrich and can be correlated through most or all the wells in the study area. The highstand floodplain deposits are a coarsening-upwards succession that shows an increase upwards in sandstone/mudstone ratio and sand bed thickness. The lacustrine and distal floodplain mudstones are interbedded with siltstones and sandstones that were deposited as levee deposits, crevasse splays and crevasse deltas. Channel sandstones are less common than in the transgressive floodplain deposits. The coarsening-upwards succession of proximal floodplain deposits developed as a result of decreasing rates of base-level rise and accommodation space generation.

Similar successions in non-marine settings have been referred to the highstand systems tract by Shanley \& McCabe (1991, 1993), as highstand depositional systems by Wright \& Marriott (1993) and as the uppermost heterolithic interval by Olsen et al. (1995).

\section{Sequences of the lower Bryne Formation}

The Bryne Formation consists of seven sequences of alluvial plain or fluvially-dominated coastal plain deposits. The Aalen-1, Baj-1 and Bat-1 regional sequences of Andsbjerg \& Dybkjær (2003, this volume) are subdivided here into the Aalen-1A, Aalen-1B, Baj-1A, Baj-1B, Bat-1A and Bat-1B sequences. The uppermost part of the Bryne Formation is included in the Cal-1A sequence (see below) that also includes sediments referred to the Lulu Formation (Fig. 4).

Aalen-1A sequence. The deposits located between the base Middle Jurassic unconformity and the first intraMiddle Jurassic sequence boundary (SB Aalen-1B) are referred to the Aalen-1A sequence. Due to onlap of the pre-Middle Jurassic subcrop the Aalen-1A sequence is only seen in wells that penetrate the deepest parts of the Middle Jurassic.

Aalen-1B sequence. Channel sandstone unit A is referred to the LST/TST of sequence Aalen-1B. Most of the floodplain deposits separating channel sandstone units A and B1 form the HST of Aalen-1B.

Baj-1A sequence. Channel unit B1 and the coarseningupwards unit of floodplain deposits between B1 and B2 form sequence Baj-1A.

Baj-1B sequence. This sequence is made up of channel sandstone unit B2 and the fining-upwards - coarsening-upwards succession of floodplain deposits separating unit B2 from unit $\mathrm{C}$.

Bat-1A sequence. In most wells, channel sandstone unit $\mathrm{C}$ forms the LST/TST of sequence Bat-1A. The HST is a unit of coarsening-upwards floodplain deposits.

Bat-1B sequence. The Bat- $1 \mathrm{~B}$ sequence is not present in the westernmost wells where it has been removed by erosion at the Cal-1A SB. Where present, it consists of channel sandstones above the SB and a finingupwards - coarsening-upwards succession of floodplain and lacustrine deposits (Fig. 15).

\section{Recognition of the intra-Bryne regional unconformity}

In the Middle Jurassic succession, a number of units and surfaces can be readily correlated across the Søgne Basin. In most of the Bryne Formation, sequence boundaries and maximum flooding surfaces are important correlatable key surfaces that are recognisable on both well logs and core logs. The maximum flooding surfaces occur within the mudstone-dominated floodplain deposits between the main channel storeys, being defined by the turnaround point between intervals with increasing-upwards and decreasing-upwards gamma-ray 
readings (Fig. 4). In the Lulu Formation (see below), the best markers are coal beds, which are easily recognisable on sonic logs and possibly represent initial flooding surfaces'. Other surfaces that prove useful for correlation are maximum flooding surfaces (MFS) in the more marine intervals and channel-base diastems in the paralic successions (Fig. 4).

Well-to-well correlation of the coal beds in the Lulu Formation suggests a sub-parallel arrangement, i.e. that thickness variations are insignificant. These markers are, however, discordant with the marker surfaces in the lower Bryne Formation (Fig. 4). The thickness of the succession between the Bat-1A MFS, which is the uppermost key surface of the Bryne Formation that is easily recognisable in almost all wells of the Søgne Basin, and the lowermost coal of the Lulu Formation varies from $12 \mathrm{~m}$ in West Lulu-4 to $110 \mathrm{~m}$ in 3/7-4 and $100 \mathrm{~m}$ in Amalie-1. This asymmetry may have resulted both from a higher rate of accommodation space generation in the eastern part of the basin due to faulting at the eastern boundary fault and from erosion in the western part of the basin. The boundary between the succession with markers that parallel the Lulu Formation coal beds and the succession with the non-parallel markers seems to be the Cal-1A SB which is a distinct erosion surface at the base of the stacked channel sandstones that dominate much of the upper Bryne Formation.

Below this sequence boundary (Cal-1A SB), a succession that includes two key surfaces (Bat-1B SB and Bat-1B MFS) can be recognised in the West Lulu-1, 3/7-4, Lulita-1, Lulu-1 and Amalie-1 wells. This succession is missing from the wells in which the stacked channel sandstones above Cal-1A SB show their largest thickness (West Lulu-2, West Lulu-3), suggesting that the missing section is due to erosion at the Cal-1A SB and not to up-dip condensation (Figs 4, 15). However, in West Lulu-4, which is located furthest up-dip of the studied wells, the section between the Cal-1A SB and the Bat-1A MFS is thin although no significant erosion surface is recognised below the lowermost coal of the Lulu Formation. This may suggest that the section in this well is condensed rather than missing (Figs 4, 16; Fig. 16 follows page 332). The basinwide extent of the Cal-1A SB erosion surface and the variable but often significant amount of section that seems to have been erosionally removed suggests that the surface is an unconformity with significant relief. The stepwise increase over a relatively short distance of the thickness of the stacked channel sandstones between Cal-A SB and the lowermost coal in the Lulu Formation and the commonly associated increase in the amount of missing section below Cal-1A SB suggest that the unconformity represents the basal surface of an incised valley.

The base of the lowermost coal in the Lulu Formation is the first surface above the unconformity that can be correlated to all wells. In West Lulu- 4 , an interfluve surface is inferred within the $10 \mathrm{~m}$ thick succession of floodplain deposits that separate the lowermost coal of the Lulu Formation from the Bat-1A MFS.

The occurrence of the dinoflagellate cyst Impletosphaeridium varispinosum in the basal part of the valley-fill in West Lulu-1 and West Lulu-3 suggests a Late Bathonian - Early Callovian age for the unconformity. This is supported by the presence of the LOD of Quadraeculina anelliformis in the same interval.

\section{Upper Bryne and Lulu Formations}

\section{Depositional architecture and environments of the upper Bryne Formation}

The upper Bryne Formation consists of the sediments between the regional unconformity (Cal-1A SB) and the first thick coal seam at the base of the Lulu Formation (Figs 4, 16). The regional unconformity is interpreted to form the base of a system of incised valleys in the Søgne Basin. The southern margin of an E-W-trending valley is inferred to be situated between West Lulu-4 and West Lulu-2 (Fig. 1). The valley axis is interpreted to be close to the wells showing the thickest valley-fills, i.e. West Lulu-3 and Lulita-1. The position of the northern valley margin is not known due to lack of well data. Work on incised valleys from the Carboniferous of the North Sea area shows that valley-fills with a maximum thickness of 30-40 $\mathrm{m}$ as seen in the upper Bryne Formation, usually correspond to a valley width of at least 5-6 km (Hampson et al. 1999).

In the wells penetrating the more proximal parts of the valley (West Lulu-1, West Lulu-2, West Lulu-3), massive channel sandstones are present throughout the succession from the basal unconformity to the overlying coal seam (Fig. 16). In wells further to the east and to the south, heterolithic and muddy deposits dominate the upper part of the succession. This is most pronounced in Amalie-1, which is inferred to penetrate a different valley branch, where $12 \mathrm{~m}$ of mudstones and heteroliths are located between the uppermost sandstone body and the coal (Fig. 17, following page 332).

The channel sands in the proximal wells occur as two to three storeys of amalgamated and stacked channel 
sandstones separated by fine-grained deposits. Each sandstone storey commonly consists of an amalgamated sandstone unit without a distinct grain-size trend although poorly defined fining-upwards trends may occur (e.g. top upper channel storey of West Lulu-3; Fig. 16). The storeys vary in thickness from approximately $5 \mathrm{~m}$ to $18 \mathrm{~m}$ (e.g. West Lulu-3). The valley-fill is a compound fill (Zaitlin et al. 1994), deposited during several minor base-level cycles. It contains significant erosion surfaces in addition to the principal sequence boundary at the base of the incised valley and one or two flooding surfaces on top of the channel storeys.

A conglomerate of intraformational mudstone clasts, up to $60 \mathrm{~cm}$ thick, may be present at the base of the lowermost channel sandstone (the basal unconformity, Cal-1A SB; Figs 6L, 16). Most sandstones of this succession belong to facies association 5 , being characterised by trough and possibly planar cross-bedding, abundant coal and mudstone clasts on foresets and bed boundaries, double mud laminae, flaser bedding and rare bimodal cross-lamination (Figs $6 \mathrm{C}-\mathrm{H}, 16$ ). They are interpreted as estuary channel and bar deposits. Bioturbated organic-rich sandy mudstones that separate the upper and middle sandstone storeys in West Lulu-3 represent lagoonal deposits that developed during a flooding event (Figs 6I, 16). Most sandstones show some degree of tidal influence, as exemplified by the lowermost and uppermost channel storeys of West Lulu-1 (Fig. 16). They are interpreted as the fill of tidal channels, deposited mainly as point bars in major estuary channels (see comparable features in Fenies \& Faugères 1998, fig. 8). The middle channel storey of West Lulu-3 is an example of a sandstone unit that lacks clear evidence of tidal conditions and may represent a fluvial deposit (Fig. 16). The lowermost sandstone bed (1 m thick) in West Lulu-2 also shows no evidence of tidal conditions, and may represent a preserved lowstand fluvial deposit (Fig. 16).

In the 3/7-4 and Lulu-1 wells, in the northern and central part of the study area, the sandstone units are thinner, typically $2-5 \mathrm{~m}$ thick (Fig. 17); they are separated by mudstone-dominated units $2-6 \mathrm{~m}$ thick (Fig. 17).

Sandstone units and heteroliths may show a finingupwards pattern, but coarsening-upwards units also occur. Sandstones show trough cross-bedding, wavy, flaser and lenticular bedding, bi-directional ripple crosslamination and double mud drapes indicating a tidal environment (Fig. 8A). Some beds are highly altered by soft sediment deformation and locally by pedogenesis. A few thin coal beds with associated root horizons that occur within the succession suggest periods with veg- etation cover. The fining-upwards units represent minor tidal channels. Sand-dominated coarsening-upwards units may have been deposited as bay-head or tidal deltas, or as tidal channel bars. Heterolithic coarseningupwards beds may represent tidal flat deposits. The combination of an overall tidal setting involving dominantly fine-grained or heterolithic sediments, with only minor channel sandstones as seen in 3/7-4, is indicative of deposition in the outer or marginal part of an estuary (Dalrymple et al. 1992). The Lulita-1 well displays thicker sand units than in the 3/7-4 well, but thinner and slightly more fine-grained than in West Lulu-3; this suggests that Lulita- 1 was situated close to the channel-dominated axial part of the estuary but downstream from the West Lulu wells.

In the southernmost part of the basin (Amalie-1), the lower $30 \mathrm{~m}$ of the succession is dominated by up to $12 \mathrm{~m}$ thick sandstone units that fine upwards or show no visible grain-size trend (Fig. 17). Although locally structureless with only faint trough cross-bedding, these sandstones commonly show trough cross-bedding, with foresets outlined by mud drapes, or ripple cross-lamination and grade up into heterolithic beds with flaser, wavy and lenticular bedding (Fig. 8C-F). Mudstone flakes are abundant in some sandstone beds; waterescape structures are also common in places. The uppermost $11 \mathrm{~m}$ of the succession mainly consist of finegrained heteroliths and mudstone (Fig. 8B). Amalie-1 is located approximately $12 \mathrm{~km}$ south of the inferred valley axis trending from West Lulu-3 to Lulita-1 so that Amalie-1 is thought to penetrate the valley-fill deposits of a separate, N-S-trending valley.

The occurrence of fine-grained heterolithic deposits in the upper part of the succession in the wells to the east and south-east may indicate an up-dip shift of facies due to a relative sea-level rise, with tidal flat and lagoonal facies becoming dominant in the lower reaches of the valley. However, this may also have resulted from an autocyclic shift of facies in an outer estuary environment, where widespread tidal flats bordered tidal channels. It is also possible that the shift to fine-grained sedimentation represents a change to deposition unconfined by valley walls when infill was complete in the lower reaches of the incised valleys.

\section{Depositional architecture and environments of the Lulu Formation}

Viewed in an east-west transect across the western and central parts of the Søgne Basin, the Lulu Formation 
consists of three eastwards-thinning wedges of mainly paralic deposits and two westwards-thinning wedges of shallow marine and coastal deposits (Figs 3, 18, 19, 20B; Figs 18, 19 follow page 332). At the top of the Lulu Formation is a transgressive unit of shallow marine and coastal deposits, a few metres thick. Two regionally extensive coal seams/coal zones can be traced across the basin; one separates the Lulu Formation from the Bryne Formation and the other divides the Lulu Formation into a lower and an upper part of almost equal thickness (Fig. 20B).

\section{Coals}

The basal coal seam, locally split into several thinner seams, is up to $5 \mathrm{~m}$ thick in the Søgne Basin. Petersen \& Andsbjerg (1996) have described this basal coal from West Lulu-2 as seams R1 and T2, which record a relatively dry peat-forming environment below (R1) succeeded by a waterlogged peat-forming environment above (T2). The coal seam is a single, almost structureless coal bed in West Lulu-1 and 3/7-4 but is represented by two or three distinct coal beds in West Lulu-2, West Lulu-3 and West Lulu- 4 and by a zone of interbedded thin coals and lagoon and marsh sediments in Lulu-1 and Amalie-1. The upper coal seam divides the Lulu Formation into a lower and an upper part of almost equal thickness (Figs 18, 19). This seam is located in the middle wedge of the three eastwards-thinning paralic wedges and can be correlated throughout the study area. It occurs as a single $0.2-0.4 \mathrm{~m}$ thick coal bed in the central and southern part of the Søgne Basin, and as two coal beds (max. $2 \mathrm{~m}$ thick) in the westernmost wells.

\section{Paralic wedges}

The three paralic wedges thin from the west towards the east. Excluding the lower coal zone, the lower paralic wedge is $11-13 \mathrm{~m}$ thick in the West Lulu-1, West Lulu-2 and West Lulu-3 wells (Fig. 18), $7 \mathrm{~m}$ thick in $3 / 7-4$ and $1-3 \mathrm{~m}$ thick in the Lulita-1, Lulu-1 and Amalie-1 wells (Fig. 19). It is bounded below by the top of the lower coal seam/coal zone and above by a distinct flooding surface that separates it from deposits of the lower marine wedge.

In the western part of the basin, the geometry of the middle paralic wedge is poorly constrained. The marine flooding surface that separates the middle paralic wedge from the upper marine wedge can be placed at two alternative positions in the West Lulu-3 well - at a gamma- ray pick in an uncored section at $3639 \mathrm{~m}$ and at a waveinfluenced heterolithic sandstone bed at $3626 \mathrm{~m}$ (Fig. 18). The latter interpretation implies an even more dramatic westwards-thickening of the middle paralic wedge than that seen for the lower paralic wedge. The former is preferred here, i.e. the flooding surface is placed at approximately the same level, above the upper regional coal marker, as in West Lulu-1 (Fig. 18). In West Lulu-2 and West Lulu-3, the lower boundary of the wedge is a channel-base diastem (Cal-1B SB). In all other wells, the boundary is picked at the top of the beach deposits that terminate the coarsening-upwards marine succession of the lower marine wedge. The thickness of the wedge in the westernmost wells is $3 \mathrm{~m}$ in West Lulu-1, $6 \mathrm{~m}$ in West Lulu-2 and $10 \mathrm{~m}$ in West Lulu-3. In 3/7-4, Lulita-1, Lulu-1 and Amalie-1, the wedge has a constant thickness of approximately $2 \mathrm{~m}$.

The upperparalic wedge attains a thickness of $20 \mathrm{~m}$ in West Lulu-3, $21 \mathrm{~m}$ in West Lulu-2, $8 \mathrm{~m}$ in 3/7-4, and 3-6 $\mathrm{m}$ in Lulita-1, Lulu-1 and Amalie-1. Much of the wedge is assumed to have been removed by faulting in West Lulu-1. The lower boundary is a distinct channel-base diastem (Cal-1C SB) in the West Lulu-2 well but is located at the shift from the shoreface and foreshore deposits of the upper marine wedge to the overlying strandplain and back-barrier deposits in the wells further to the east. In West Lulu-3 and West Lulu-1, the boundary has been placed at the erosional base of a coarsening-upwards sandstone unit interpreted as tidal bar or mouth bar deposits of a prograding bay-head delta, sitting below the Cal-1C SB. The upper boundary is the final marine flooding surface below the transition to the offshore mudstones of the Lola Formation. This surface is placed at the base of a $1.5 \mathrm{~m}$ thick transgressive sandstone bed in 3/7-4, and in West Lulu-2 and West Lulu-3 at the base of a transgressive conglomerate/pebbly sandstone unit.

In the West Lulu-2 well, the paralic wedges are dominated by up to $10 \mathrm{~m}$ thick storeys of stacked sandstone units that fine upwards or show no grain-size trends. In the West Lulu-1 and West Lulu-3 wells, the paralic wedges are characterised either by coarsening-upwards mudstone-sandstone successions or by sandstones showing no clear overall grain-size trends. Both coarsening-upwards and fining-upwards sandstones occur in 3/7-4. The sandstones show trough cross-bedding, current ripple cross-lamination and double mud drapes. Climbing ripple cross-lamination and bioturbation (abundant Teichichnus isp. burrows, less common Planolites isp. and Skolithos isp.; Fig. 9A, B) occur frequently in the coarsening-upwards units and the units showing no 
grain-size trends. Flaser bedding, soft-sediment deformation structures and beds with abundant coal and mudstone clasts are characteristic of the fining-upwards sandstone units. Heterolithic intervals show wavy and lenticular bedding. The coarsening-upwards successions are interpreted as tidal bar deposits or mouth bar deposits of prograding bay-head deltas. The sandstone units that fine upwards or show no grain-size trends represent the fill of major estuary channels. Minor finingupwards sandstone beds within, and typically near the top of, coarsening-upwards successions, may represent bay-head delta distributary channels.

In both 3/7-4 and Lulita-1, the $c .1 \mathrm{~m}$ thick sandstonedominated lower part of the upper paralic wedge consists of a succession of parallel-laminated and low-angle cross-bedded sandstones interpreted as strandplain deposits. This is overlain by a heterolithic unit, up to $2.5 \mathrm{~m}$ thick, showing flaser, wavy, and lenticular bedding deposited in a low-energy estuary or lagoon environment. In 3/7-4, the heterolithic succession is abruptly overlain by a $3 \mathrm{~m}$ thick unit of stacked sandstones with coal and mud clasts, which fines upwards into an organic-rich, heterolithic mudstone with abundant roots, and finally a coal bed. These sandstones are interpreted as the fill of a minor distributary channel.

In the Lulu-1 and Amalie-1 wells, located in the central and southern part of the basin, the lower paralic wedge is represented solely by coals with interbedded clastic sediments of the lower coal zone. Paralic deposits above the coals have been reworked and incorporated in the lower marine wedge during transgression. The middle and upper paralic wedges consist of $1-1.5 \mathrm{~m}$ of poorly sorted, structureless sandstone with abundant coal debris and root traces; the sandstone may show irregular ripple cross-lamination. These deposits are interpreted as mainly strandplain deposits. The upper coal seam/coal zone is situated within the middle paralic wedge. The occurrence of minor coal beds and root horizons indicates periods with vegetation cover and peat accumulation.

\section{Marine depositional wedges}

The two marine wedges both thin towards the west. The lower marine wedge attains a thickness of $7.5-11.5 \mathrm{~m}$ in the Lulita-1, Lulu-1 and Amalie-1 wells, c. $3 \mathrm{~m}$ in 3/7-4 and West Lulu-1, and only about $1 \mathrm{~m}$ (preserved thickness) in West Lulu-2 and West Lulu-3 (Figs 18, 19). The upper marine wedge is approximately $10 \mathrm{~m}$ thick in the Lulita-1, Lulu-1 and Amalie-1 wells and attains a thickness of $6 \mathrm{~m}$ in 3/7-4 and $5 \mathrm{~m}$ in West Lulu-1. In West
Lulu-3 and West Lulu-2, it is represented by an approximately $1 \mathrm{~m}$ thick mudstone bed.

In both Lulu-1 and Amalie-1, the basal part of the lower marine wedge consists of an erosionally based, fining-upwards silty sandstone unit, 40-60 cm thick. The sandstone becomes increasingly heterolithic or muddy upwards, but primary structures have been obliterated by pervasive bioturbation (Fig. 11A). The sandstone is interpreted as a transgressive shelf deposit. It is overlain by a unit of shelf mudstones that varies in thickness from about $0.5 \mathrm{~m}$ in Lulu- 1 to approximately $11 \mathrm{~m}$ in Amalie-1, where it shows a coarsening-upwards trend. Above the mudstone unit in Lulu-1, Lulita-1 and Amalie-1 is an 8-12 m thick, coarsening-upwards succession. The basal part of the coarsening-upwards succession consists of mudstone-sandstone heteroliths, showing lenticular and parallel bedding/lamination and wave ripple cross-lamination in sand laminae. It is overlain by sand-dominated heteroliths with abundant hummocky cross-stratification, sandstones with low-angle and swaley cross-stratification and trough cross-bedding, and uppermost by parallel bedded and low-angle crossbedded sandstone (Figs 11A-F, 19). This represents a progradational succession from offshore transition to lower shoreface sediments overlain by upper shoreface and beach deposits.

The wave-dominated sediments of the lower marine wedge can be traced to the west in West Lulu-1 and $3 / 7-4$ as a unit up to $4.5 \mathrm{~m}$ thick. In West Lulu-1, a pebble veneer interpreted as a wave ravinement lag defines the base of the wedge. This is succeeded by a $0.5 \mathrm{~m}$ thick unit of hummocky cross-stratified and wave-rippled sandstone overlain by a thin mudstone and a $3 \mathrm{~m}$ thick coarsening-upwards sandstone unit dominated by swaley cross-stratification and low-angle cross-bedding with abundant Teichichnus isp. burrows. In the 3/7-4 well, the base of the wedge is picked at a flooding surface below which the uppermost paralic deposits are strongly bioturbated. The deposits of the marine wedge form several $0.5-2.5 \mathrm{~m}$ thick, coarsening-upwards sandstone units showing wave ripple lamination, lowangle cross-bedding and hummocky and swaley crossstratification. Teichichnus isp. burrows are common. In both West Lulu-1 and 3/7-4, this succession is interpreted as a condensed shoreface or a wave-influenced mouth bar. In West Lulu-2 and West Lulu-3, the westernmost correlative of the lower marine wedge consists of a few metres of mudstone. Thorough bioturbation with abundant Teichichnus isp. burrows in the top of the underlying paralic deposits indicates that a marine or brackish flooding event preceded deposition of the 
mudstone. Erosion at the Cal-1B SB has removed all shallow marine or coastal deposits of the lower marine wedge that may have overlain the mudstone.

In the upper marine wedge, the shoreface succession in Lulita-1 and Lulu-1 is represented by three stacked, 1.2-4 $\mathrm{m}$ thick, coarsening-upwards parasequences separated from each other by minor flooding surfaces. Further to the north in 3/7-4, the $10 \mathrm{~m}$ thick upper marine wedge has a similar architecture with three parasequences ( $2 \mathrm{~m}, 2 \mathrm{~m}, 6 \mathrm{~m}$ ) separated by distinct flooding surfaces. Each parasequence consists of a basal unit of heterolithic sandstones and mudstones that coarsens upwards to sandstones dominated by wave-generated structures, suggesting a shoreface origin (Fig. 12D-J). In 3/7-4, the facies assemblage indicates deposition in a mixed wave- and tide-dominated environment, possibly a tidally influenced mouth-bar or an ebb tidal delta. In West Lulu-1, the upper marine wedge consists of a $3.5 \mathrm{~m}$ thick coarsening-upwards unit (Fig. 12A-C). It comprises heterolithic siltstone and sandstone showing parallel lamination, wave ripple lamination, lenticular bedding, and hummocky cross-stratification, and sandstone showing low-angle cross-bedding and possibly swaley cross-stratification. Both in West Lulu-1 and 3/7-4, Teichichnus isp. and Diplocraterion isp. burrows are common. The abrupt upwards termination of the wedge in West Lulu-1 may be caused by a normal fault. The succession in West Lulu-1 represents a wavedominated environment, interpreted as a progradational shoreface deposited in an area with limited accommodation, or a wave-influenced mouth bar.

\section{Final transgressive deposits}

The channel and estuarine bar sandstones of the upper paralic wedge are erosionally overlain by an up to $4 \mathrm{~m}$ thick unit consisting of sandstones and pebble conglomerates. The base of this unit is commonly outlined by a pebble veneer draping an erosion surface. In West Lulu-3, this unit includes several erosionally-based beds, up to $10 \mathrm{~cm}$ thick, of graded clast-supported pebble conglomerate (Fig. 10F). Interbedded with the conglomerates are beds of well-sorted sandstone and pebbly and granule-rich sandstone. In 3/7-4, this part of the succession is represented by a $1.5 \mathrm{~m}$ thick heterolithic sandstone dominated by wave ripple lamination and wavy- and lenticular bedding.

The erosional surface that lies at the base of the conglomerates in West Lulu-2 and West Lulu-3 and separates the tidally influenced sandstones from the overlying fine-grained marine sediments in Lulu- 1 and $3 / 7-4$, is interpreted as a transgressive surface of marine erosion (TSME) or ravinement surface. The coarse-grained sediments above the ravinement surface in West Lulu-2 and -3 were deposited as beach and shoreface deposits during transgression (Bourgeois \& Leithold 1984). Sediments of that grain size are rare in the underlying succession, and they are therefore interpreted as the result of storm-wave reworking of coarse fluvial sediments supplied to the near-shore zone. The graded pebbly sandstones sandwiched between the conglomerates and the overlying marine mudstones in West Lulu-2 (Fig. 10A, B) represent rapid deposition of sediment eroded by waves breaking on the shoreface (Bourgeois \& Leithold 1984).

Sequence stratigraphy of the upper Bryne Formation and the Lulu Formation

\section{Key surfaces}

Within the mainly estuarine deposits of the upper Bryne Formation, flooding surfaces (FS) separate stacked channel sandstones from overlying lagoonal or marine mudstones. Channel-base diastems that can be correlated throughout the incised valleys possibly represent sequence boundaries of higher order sequences although no attempt has been made to subdivide that part of the succession further.

In tidally dominated paralic units in the Lulu Formation, sequence boundaries are defined by channel-base diastems (Fig. 18). In marine intervals, the sequence boundaries occur as indistinct surfaces that separate beach deposits from overlying strandplain deposits (Fig. 19).

In the wells located in the central and southern parts of the study area, the basal sequence boundaries of the Cal-1B and the Cal-1C sequences are placed immediately above the beach deposits that form the top of the prograding shoreface successions (Fig. 19). The shift from beach deposits to the overlying laterally extensive coalbearing or rooted beds indicates a basinwards shift of facies. In 3/7-4, the Cal-1B SB $(3460 \mathrm{~m})$ is identified at the base of a rooted sandstone bed sitting on top of the condensed shoreface or mouth bar succession that comprises the HST of Cal-1A; in this well, the Cal-1C $\mathrm{SB}$ is placed at the base of a rooted channel sandstone (3449 m). In West Lulu-1, the Cal-1B SB is represented by a bed of pebbly sandstone (core rubble) at $3572 \mathrm{~m}$. In the West Lulu-2 and West Lulu-3 wells, the Lulu Formation is dominated by stacked channel sandstones; the sequence boundaries of the Cal-1B and Cal-1C sequences are placed at the base of coarse-grained 
channel sandstones in these wells. The Cal-1B SB cuts into lagoonal mudstones in West Lulu-3 (Fig. 7C) and the Cal-1C SB cuts into lagoonal mudstones in West Lulu-2 (Fig. 10E; 3799 m). These lagoonal mudstones may include the Cal-1A and Cal-1B maximum flooding surfaces although these surfaces may have been truncated by the channel base diastem. The Cal-1B SB is located at the base of a thin sandstone at $3808 \mathrm{~m}$ in West Lulu-2; the Cal-1C SB is picked at the erosional base of a channel sandstone unit in West Lulu-3 at $3625 \mathrm{~m}$. A marine flooding surface subdivides this sequence (Cal-1C) into a lower unit dominated by paralic sandstones (uppermost Lulu Formation) and a mudstonedominated upper unit (lowermost Lola Formation). In some wells, a transgressive surface of marine erosion (ravinement surface) can be seen immediately below the flooding surface.

An erosion surface that separates shelf mudstones and shoreface transition heteroliths from overlying shoreface sandstones is interpreted as a regressive surface of marine erosion (RSME); it is located at 3582 metres in Lulu-1, 4433 metres in Lulita-1, 3457 metres in 3/7-4 metres and at 3565 metres in West Lulu-1 (Figs 18, 19). The shoreface sandstones above the RSME are referred to the falling stage systems tract (FSST).

\section{Systems tracts}

In the valley-fill deposits that constitute the upper Bryne Formation, LST-deposits of the Cal-1A sequence, if present, are to be found among the massive channel sandstones that dominate the valley-fill. However, most of these channel sandstones show clear evidence for tidal processes, and are referred to the TST, recording an increase in the rate of relative sea-level rise. During the lowest sea-level stand, incised valleys acted as conduits for sediment by-pass, and much of the fluvial sediment deposited within the valley may have been eroded and shed further basinwards. A preserved fluvial sandstone bed, $1 \mathrm{~m}$ thick, at the base of the valley-fill succession in West Lulu-2 may represent the LST of the Cal-1A sequence (Fig. 16). In the Cal-1B and Cal-1C sequences, channel deposits directly overlying the sequence boundaries in the West Lulu-2 and West Lulu-3 wells show evidence of strong tidal influence (Figs 7A, B, C, 10D). The thin sedimentary section between the Cal-1B SB and the overlying coal in the wells further east does not show any diagnostic sedimentary structures.

A typical TST in the upper Bryne and Lulu Formations in the West Lulu area consists of a lower succession dominated by tidally influenced fluvial channel and estuary channel sandstones, some of which may have been deposited in an incised valley, and an upper succession of outer estuary and lagoonal deposits. In the wells closer to the basin axis, estuary channel deposits are only important constituents of the TST when located in an incised valley. Otherwise, the TST in this area is dominated by outer estuary, marine bay, and transgressive shoreface and shelf deposits; a ravinement surface or transgressive surface of marine erosion (TSME) normally separates the lower estuarine part of the TST from transgressive shoreface deposits. The uppermost succession of the TST normally wedges out in a basinwards direction. The TST is bounded above by the maximum flooding surface (MFS) represented by shelf or lagoonal mudstones.

In the marine successions, the HST is a coarseningupwards succession of shelf, shoreface and beach deposits. The HST wedges out in a landwards direction where the succession consists of bay-head and tidal delta deposits overlying lagoonal or bay mudstones reflecting a rapid, progradational infilling of estuaries or bays. The HST is truncated above by a sequence boundary or in some cases by a regressive surface of marine erosion (RSME). Truncation at the Cal-1B SB causes the Cal-1A HST to be absent from West Lulu-2 and West Lulu-3. Similarly, the Cal-1B HST is missing in West Lulu-2 due to erosion at the Cal-1C SB (Fig. 18).

A significant erosional break within the coarseningupwards succession of regressive shoreface deposits in the Cal-1B sequence in Lulu-1 and Lulita-1 suggests that the upper shoreface and foreshore deposits above the break were deposited during a fall in relative sea level, which caused wave erosion of the already deposited lower shoreface and shelf sediments (Plint 1988). The deposits between the erosional break (RSME) and the next sequence boundary are referred to the falling stage systems tract (FSST). The FSST consists of coarsening-upwards shoreface, estuary mouth, foreshore and beach deposits; their formation and preservation was dependent on the balance between sea-level change and subsidence. In addition to their occurrence in Lulu-1 and Lulita-1, regressive shoreface deposits may possibly be referred to a Cal-1B FSST in the West Lulu-1 and 3/7-4 wells (Figs 3, 19).

\section{Sequences of the upper Bryne and Lulu Formations}

The three sequences Cal-1A, Cal-1B and Cal-1C cover the uppermost part of the Bryne Formation, the Lulu Formation and the lowermost part of the Upper Jurassic Lola Formation (Fig. 20). 
B

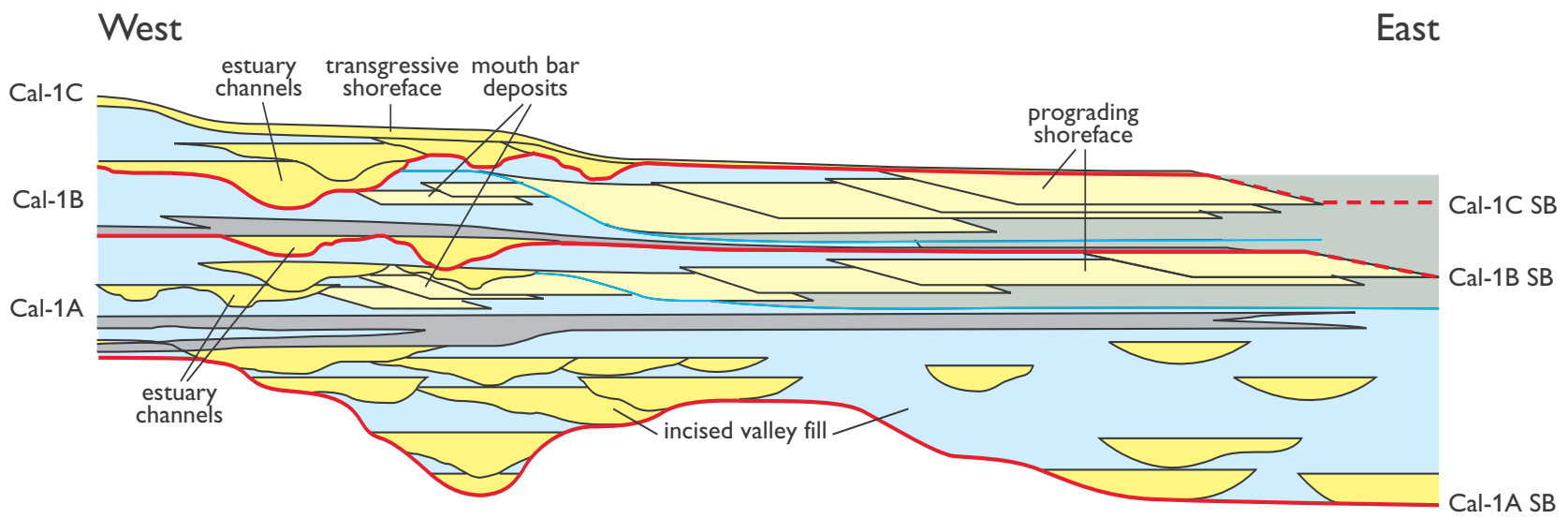

A

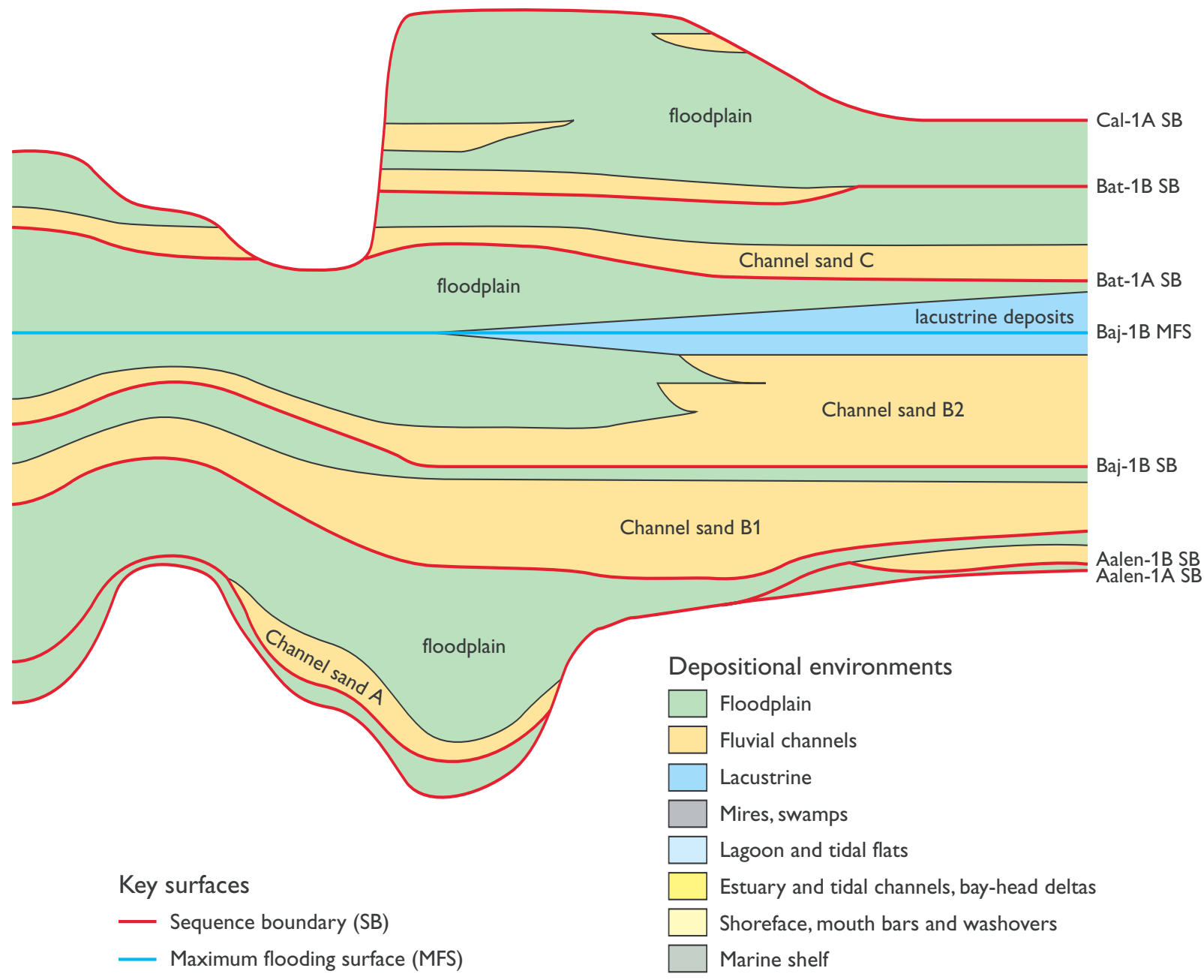

Fig. 20. Schematic representation of the sequence stratigraphy and stacking patterns of the lower Bryne Formation (A) and the upper Bryne Formation and Lulu Formation (B). 
Possible LST deposits and the lower TST of Cal-1A are represented by incised valley-fill deposits, referred to the upper Bryne Formation (Figs 16, 17). The remainder of the Cal-1A sequence is made up of the lower paralic wedge and the main part of the lower marine wedge; these are assigned to the upper part of the TST and the HST (Figs 18, 19).

In the Cal-1B sequence, possible LST deposits and most of the TST are represented by the middle paralic wedge; the upper marine wedge is assigned to the uppermost part of the TST, the HST and the FSST. The upper paralic wedge is referred to the LST(?) and the lower part of the TST of Cal-1C. The remainder of the Cal-1C sequence occurs within the lowermost Lola Formation, where the HST is represented by a progradational unit of shallow marine, strongly bioturbated mudstone and silty sandstone.

\section{Depositional history and palaeogeography}

\section{Aalenian(?) - Late Bathonian}

Between the Aalenian/Early Bajocian and the Middle/ Late Bathonian, when base level was low, the study area was dominated by an alluvial plain with laterally migrating, sinuous rivers that swept most of the floodplain (Fig. 21A). The presence of stacked, amalgamated channel sandstones in the West Lulu-1 and 3/7-4 wells in the vicinity of the Lulu salt structure and its northwards extension suggest that this area, in particular, was favoured by channels. Deposition took place on a coastal plain, where the upstream effects of tidal processes were occasionally felt in the river channels.

Recurrent periods of rising base level resulted in the abandonment of the large river channels. The area changed into a wet floodplain environment dominated by ponds and minor channels. At the time of maximum flooding, extensive lakes occupied the axial part of the basin and other topographic lows (Fig. 21B). Brackish or fully marine waters may have entered the basin on occasion to form shallow bays or lagoons, particularly in the southern part of the Danish Central Graben. Regional drainage was from the north to the south where marine conditions existed in the Dutch part of the Central Graben until the Early Bathonian (van Adrichem Boogaert \& Kouwe 1993; Hengreen et al. 2003, this volume). During periods with a decreasing rate of base-level rise, lacustrine deltas and crevasse splays filled in the lakes and lagoons, and a depositional environment dominated by laterally migrating rivers was re-established. During the Bathonian, more perennial lakes may have existed in the southern part of the Søgne Basin, while swamps developed in the northern and the central part of the basin.

\section{Late Bathonian - Callovian}

During formation of the base Cal-1A SB, major incised valleys were cut both at the western fringe of the Søgne Basin and in the south-eastern part of the basin close to the basin axis (Amalie-1; Fig. 21C). Late Bathonian - earliest Callovian datings have been obtained from the lower part of the incised valley-fill. Broad estuaries developed in the lower reaches of the incised valleys during relative sea-level rise. Deposition took place mainly in major channels in the more proximal parts of the valleys, and in outer estuary environments characterised by tidal flats, minor tidal channels and flood tidal deltas closer to the basin centre (Fig. 21C). Locally, a final phase of valley-fill is evident, characterised by fine-grained sediments deposited in tidal flat and lagoonal environments (e.g. Amalie-1; Figs 17, 22B). The general increase upwards in tidal influence and preserved thickness of channel storeys seen in many valley-fill deposits suggests that deposition took place during rising sea level.

Once the incised valleys were completely filled, sedimentation was no longer laterally confined (Fig. 22). The estuary environment was replaced by a low-energy lower coastal plain, which was dominated by extensive coal-forming mires and swamps that extended over both the infilled valleys and the former interfluve areas. Mire aggradation resulted in thick coal-generating peat deposits in the western part of the Søgne Basin, whereas coastal swamps caused the formation of thin coals and coaly mudstones in the central and southern parts of the basin. The resulting coal seam records a stepwise increase in marine influence with time, as a continuously waterlogged environment with occasional seawater incursions succeeded a relatively dry peat-forming environment (Petersen \& Andsbjerg 1996).

The growth of extensive peat-forming mires and swamps ended as a result of the combined effects of continued sea-level rise, causing transgression in the north-east, and clastic influx from up-dip sources in the west. Deposition of shelf mud began in the central part of the Søgne Basin following transgression, while a lagoonal/estuarine environment was established in the western part of the basin (Fig. 23A). Continued 

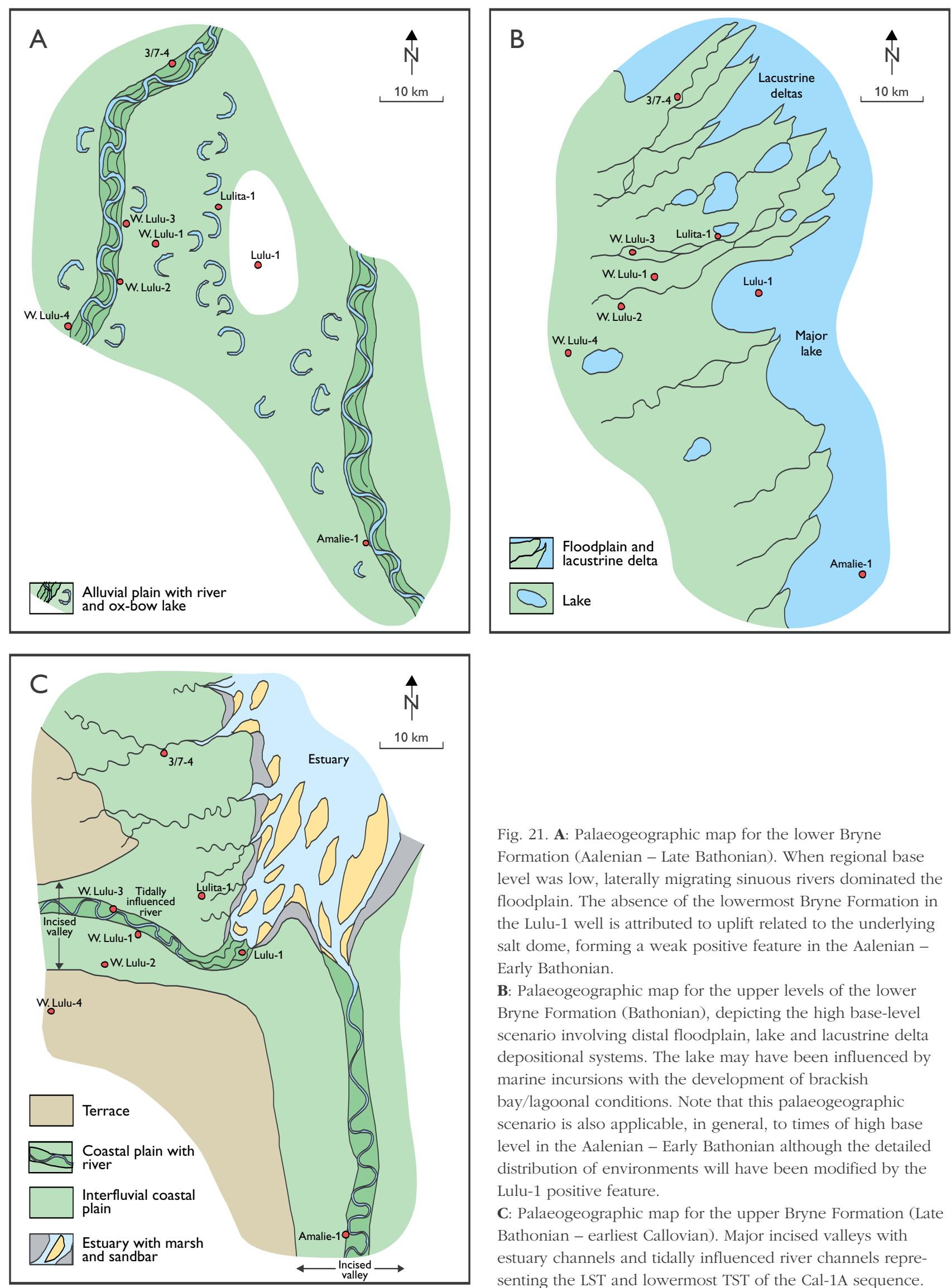

Fig. 21. A: Palaeogeographic map for the lower Bryne Formation (Aalenian - Late Bathonian). When regional base level was low, laterally migrating sinuous rivers dominated the floodplain. The absence of the lowermost Bryne Formation in the Lulu-1 well is attributed to uplift related to the underlying salt dome, forming a weak positive feature in the Aalenian Early Bathonian.

B: Palaeogeographic map for the upper levels of the lower Bryne Formation (Bathonian), depicting the high base-level scenario involving distal floodplain, lake and lacustrine delta depositional systems. The lake may have been influenced by marine incursions with the development of brackish bay/lagoonal conditions. Note that this palaeogeographic scenario is also applicable, in general, to times of high base level in the Aalenian - Early Bathonian although the detailed distribution of environments will have been modified by the Lulu-1 positive feature.

C: Palaeogeographic map for the upper Bryne Formation (Late Bathonian - earliest Callovian). Major incised valleys with estuary channels and tidally influenced river channels representing the LST and lowermost TST of the Cal-1A sequence. 

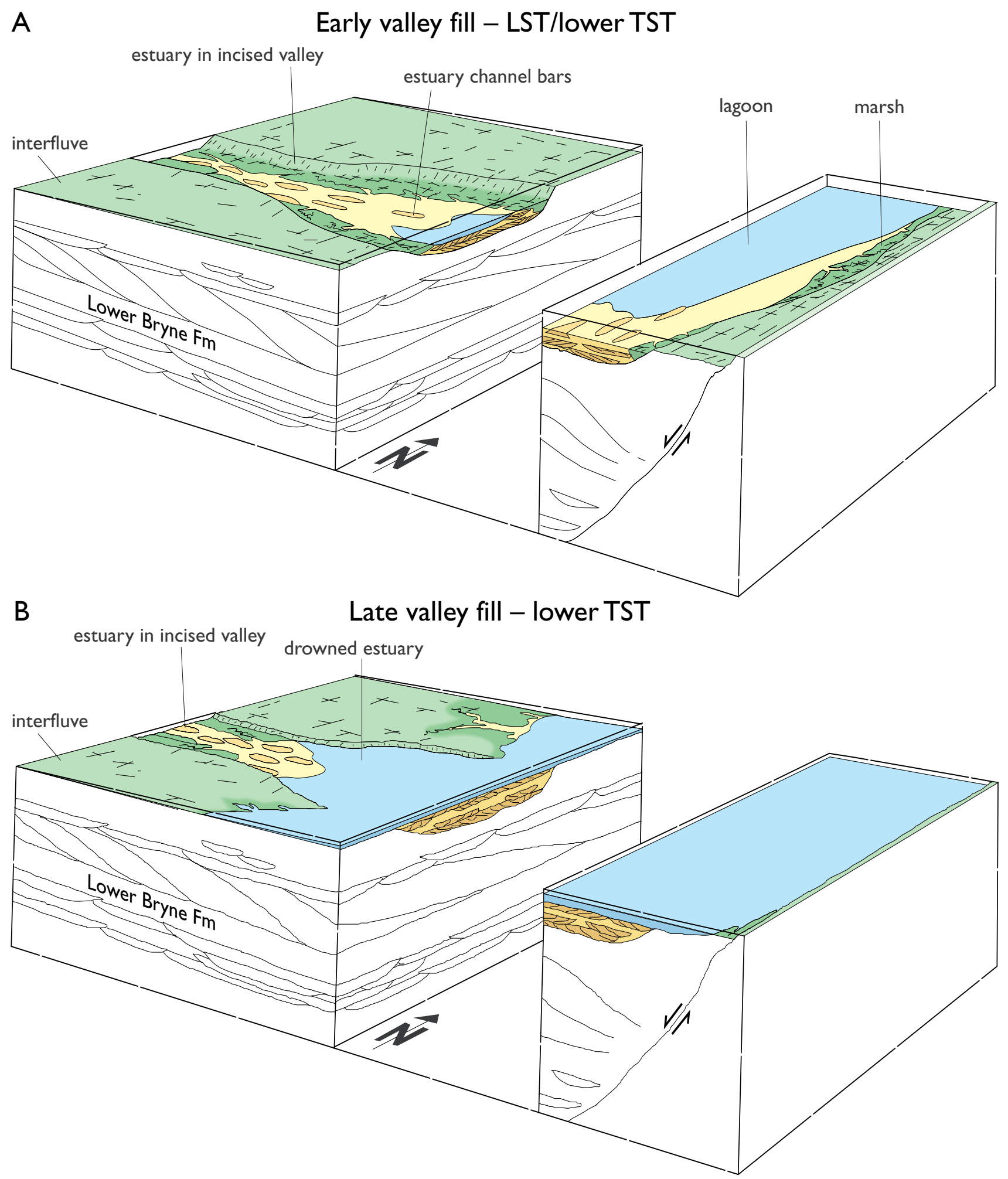

Fig. 22. Block diagram showing the inferred palaeogeography during deposition of the uppermost Bryne Formation. Deep incision, creating the Cal-1A sequence boundary, resulted in two incised valley systems, the confluence of which is depicted here. The W-E transverse system, draining the hangingwall slope, is encountered particularly in the West Lulu wells whereas the rift-axial system, trending S-N parallel with the main boundary fault, is represented by the Amalie-1 section (Fig. 21C). In their lower reaches, as depicted here, the valleys were estuarine in nature and were progressively drowned; this evolutionary phase is recorded in the lower TST of the Cal-1A sequence. 
transgression towards the west and south caused reworking of coastal and back-barrier deposits, while a progressively thicker succession of back-barrier deposits was preserved below the transgressive surface of marine erosion.

The overall transgression of the Søgne Basin was interrupted on at least two occasions by regressive phases caused by periods of relative sea-level fall or stillstand. Each regressive phase began with prograding bay-head deltas infilling lagoons and estuaries in the western parts of the area. When infilling of lagoons and estuaries was complete, sediment began to bypass the coastal zone and was supplied to the shoreface. Shoreface sediments prograded into the deeper parts of the basin forming a wedge of shallow marine and

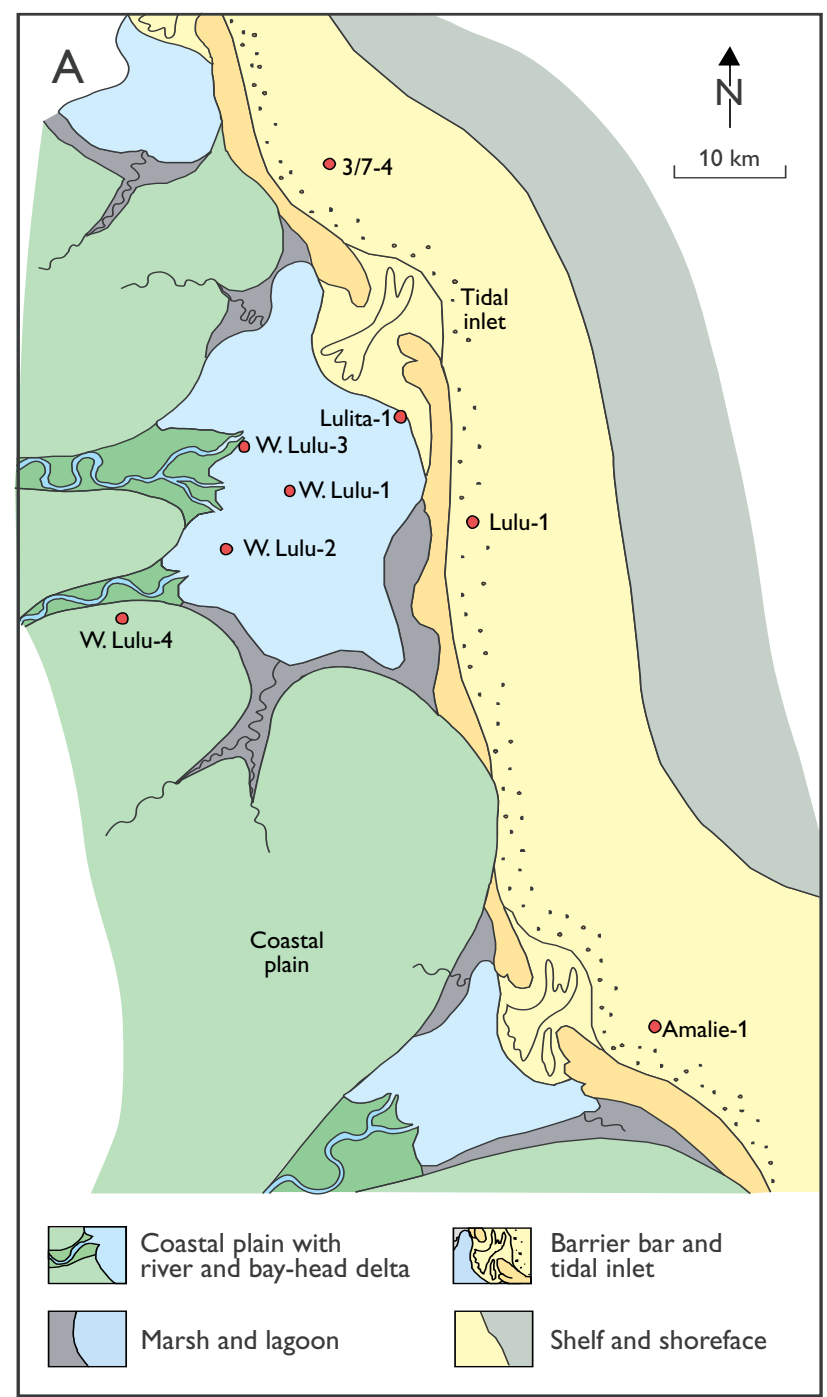

coastal deposits (Fig. 23B). If the regressive phase was associated with a sea-level fall, the decreasing accommodation caused increased wave scour on the inner shelf, and rapid progradation of the shoreface. A thin sheet of strandplain sediments deposited behind the prograding coastline is indicative of the completion of infilling. Thin extensive coal deposits that overlie the strandplain deposits indicate a shift from regression to renewed transgression.

During the final transgression of the area, probably in the Late Callovian, the top of the coastal plain deposits was eroded by wave action resulting in the formation of a ravinement surface. The rapid transition from paralic sediments to offshore mudstones and siltstones indicates a rapid transgression across a low-gradient

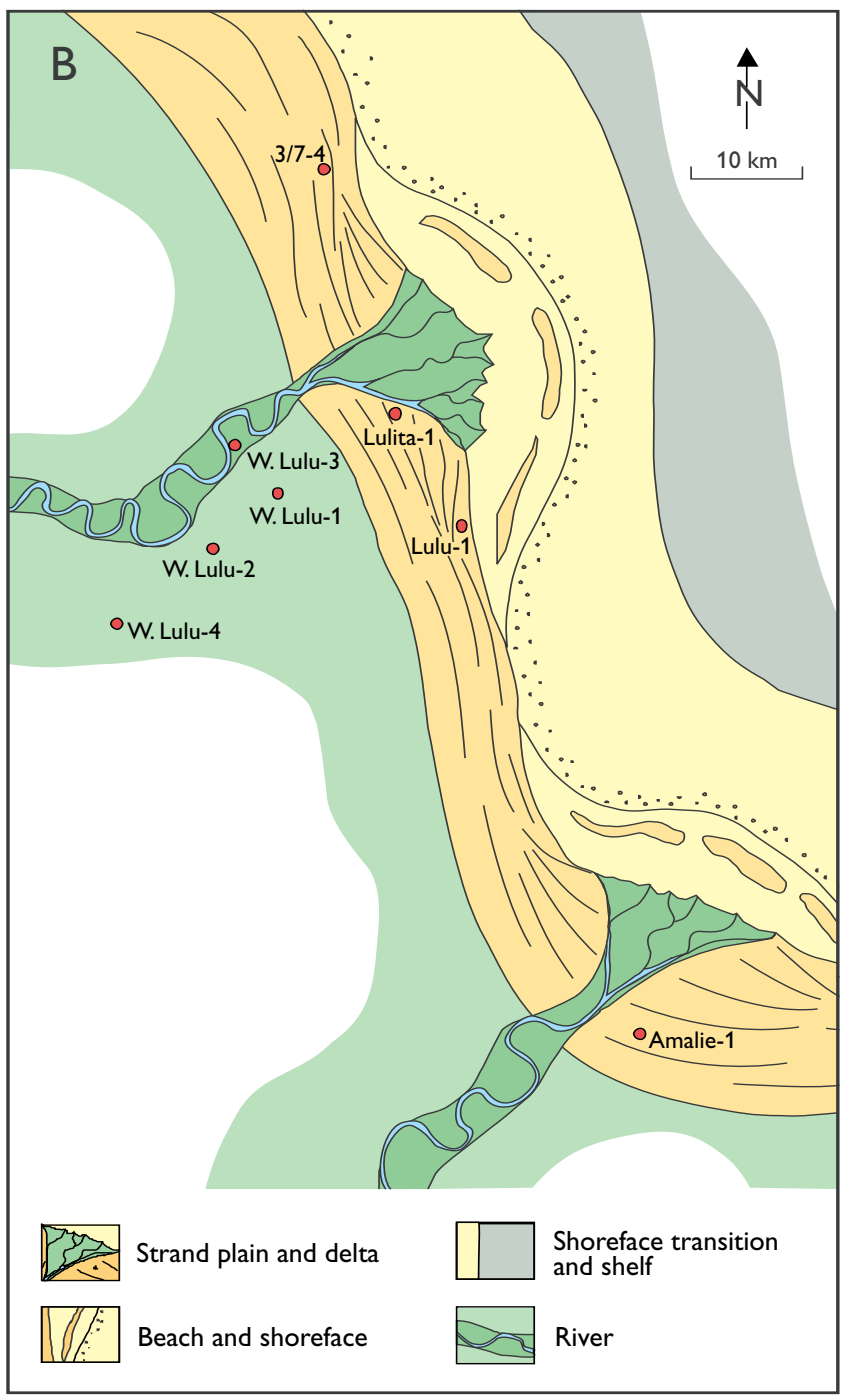

Fig. 23. A: Palaeogeographic map for the Lulu Formation (Callovian) depicting transgressive shoreface, barrier coast and coastal plain settings, a scenario recorded by the upper TST of sequences Cal-1A and Cal-1B. B: Palaeogeographic map for the Lulu Formation (Callovian). This scenario, involving progradational shoreface, beach ridge plain and alluvial plain settings, is inferred from the HST/FRST of sequences Cal-1A and Cal-1B. 
coastal plain. Sediment sources were effectively removed from the vicinity of the study area. Deposition of paralic and shallow marine sandstones of the Bryne Formation was terminated when the basin entered the rift climax phase. Sediment supply was no longer sufficient to keep pace with the increased rate of subsidence, and deposition of the Lola Formation shelf mudstones took over.

\section{Discussion}

The Middle Jurassic deposits of the Danish Central Graben form part of a major system of alluvial plain, coastal plain, delta plain and shallow marine deposits that extends over large tracts of the North Sea area. During the earliest Middle Jurassic, large-scale regional uplift, the 'North Sea doming event' and the subsequent dome collapse affected a large part of this area (Whiteman et al. 1975; Eynon 1981; Ziegler 1990; Underhill \& Partington 1993). The pre-Middle Jurassic deposits in the Danish Central Graben are cut by a major unconformity that separates the Middle Jurassic succession from the Lower Jurassic Fjerritslev Formation in the southern and central part of the Danish Central Graben and from Triassic and Permian rocks in the Søgne Basin (Andsbjerg et al. 2001).

In contrast to the Middle Jurassic in much of the North Sea area, fully marine deposits have not been found in the pre-Callovian of the Søgne Basin. In the northern Viking Graben, the lower part of the Brent Group is dominantly marine. In both the Cleveland Basin of eastern England and in the Norwegian-Danish Basin, marine deposits are well-represented in the lower part of the Middle Jurassic succession. In the Danish Central Graben, thin mudstones that yield dinoflagellate cysts occur in the lower part of the Middle Jurassic succession more than $50 \mathrm{~km}$ south of the Søgne Basin (Andsbjerg 1997). Further south in the Dutch part of the Central Graben, the Aalenian - Lower Bathonian succession comprises marine mudstones of the Werkendam Formation (van Adrichem Boogaert \& Kouwe 1993; Herngreen et al. 2003, this volume). In the northern part of the Central Graben (Gatliff et al. 1994) and in the Moray Firth (MacLennan \& Trewin 1989), Middle Jurassic deposits older than the Bathonian or latest Bajocian seem to be absent, probably due to their location near an early Middle Jurassic uplift centre.

The occurrence of marine lower Middle Jurassic deposits in the southern part of the Central Graben simultaneously with non-marine deposits in the Søgne
Basin and the possible absence of lowermost Middle Jurassic rocks in the northern Central Graben suggest that regional drainage patterns within the Central Graben was from the north towards the south, being strongly influenced by uplift patterns.

In the late Middle Jurassic, the appearance of marine deposits in the Søgne Basin simultaneously with nonmarine deposition to the south and south-west suggests a significant change in regional slope and drainage patterns. During the Callovian, drainage in the Danish Central Graben was from the west and south-west, down newly developed hangingwall slopes, and possibly from uplifted areas in the southernmost part of the North Sea.

Most of the Middle Jurassic succession was deposited during the early stages of rift-related subsidence in the Søgne Basin. At some stratigraphic levels, sediments and facies patterns show an asymmetric distribution across the basin. Between the fluvial sand sheets, lacustrine and distal floodplain deposits tend to dominate in the wells of the central and southern part of the basin closest to the main boundary fault whereas proximal floodplain deposits are dominant in the western part of the basin (Fig. 20B). The available well data do not suggest a preferred positioning of fluvial channels close to the main boundary fault, but a tendency to amalgamation and thickening of channel sands is seen in the wells near the Lulu salt structure and its northwards extension. In a relatively arid environment, fluvial channel sands parallel to the basin axis would show a tendency to cluster near the main boundary fault (Alexander \& Leeder 1987; Leeder \& Gawthorpe 1987). That this is not the case in the Søgne Basin may be explained by a setting on a coastal plain with a high groundwater level resulting in the development of lakes and wet floodplain environments in the deep parts of the basin as a response to subsidence at the main boundary fault. Under such conditions, during periods of active subsidence, transverse fluvial systems would be located on the hangingwall slope draining into the axial lakes (Alexander \& Leeder 1987; Leeder \& Gawthorpe 1987). Only during periods of tectonic quiescence could large, longitudinal fluvial systems develop after lake-infilling was complete.

In the paralic to shallow marine succession in the upper part of the Middle Jurassic section, depositional units show a spatial partitioning such that paralic sediments dominate towards the west, deposited mainly during rising sea level, and offshore-shoreface sediments dominate towards the east, deposited during highstand and possibly early fall in sea level. Such landwards partitioning of paralic deposits during trans- 
gression and seawards partitioning during highstands has been described previously by Ravnås \& Steel (1998) and is analogous to the 'reciprocal' style of sedimentation described from the Gallup Sandstone of New Mexico by Nummedal \& Molenaar (1995). Coal beds that were deposited on a low-gradient coastal plain, are overlain by paralic deposits of the TST that show a progressive increase in thickness towards the west or up-dip on the hangingwall slope (Fig. 20B). In contrast, coastal and shallow marine deposits of the HST and FSST overlying the paralic paralic wedge thicken towards the east or down-dip on the hangingwall slope. The TSME, or in some places the MFS, that separates the two wedges, thus shows a significantly higher gradient than the coal below the paralic wedge. The widespread thick coals at the base of the succession indicate initial conditions characterised by a low gradient and negligible sediment input. A transgression in that setting would be expected to be a rapid, low-angle non-accretionary transgression (Helland-Hansen \& Martinsen 1996). However, the angular difference between the coals (the original depositional surface) and the transgressive shoreline trajectory represented by the TSME and the MFS above the preserved wedge of paralic transgressive deposits is suggestive of a change in slope before or during the early phases of transgression. Thus an accretionary transgression took place, possibly after an initial phase of low-angle non-accretionary transgression (Helland-Hansen \& Martinsen 1996; Fig. 20B). The westwards-thickening wedge of paralic sediments that formed during transgression left eastwards-increasing accommodation space unfilled at the time of maximum flooding. This accommodation space was filled by prograding mainly shallow marine deposits during the subsequent highstand or possibly the falling stage, resulting in the reciprocal distribution pattern of westwards-thickening TST deposits and eastwards-thickening HST/FSST deposits (Fig. 20B).

The nature of the sediment partitioning and the occurrence of an aggradational transgression rather than a low-angle non-aggradational transgression on the hangingwall slope, as may be expected from the initial conditions, can be explained by tectonic influence. Faultinduced tilting of the original depositional surface would have caused a slower transgression of a steeper slope and a concentration of the available volume of sediment within a narrower, but thicker on-lapping sediment prism. Thick back-barrier deposits accumulated below the ravinement surface or TSME, while a sheet of transgressive shelf sands was shed seawards. After infill of the remaining accommodation space with HST/FSST deposits, re-establishment of coal-forming mires and swamps indicates a new tectonically quiescent phase. Thus periods characterised by tectonic quiescence and slow uniform subsidence alternated with episodes of faulting at the main boundary fault, when the hangingwall slope was re-established and the newly created accommodation space was filled. However, compaction of thick peat may also have favoured the preferential preservation of transgressive deposits in the western part of the Søgne Basin where the thickest coals are found. Similar relationships have been described by Ravnås \& Steel (1998) from the Middle Jurassic Tarbert Formation in the northern North Sea. These workers described how the destruction of shoreline barriers by steep-trajectory transgression resulted in sediment being partitioned landwards and seawards.

Both the overall, gradual change from alluvial plain or fluvially dominated coastal plain deposits in the lower part to dominantly tidal and shallow marine deposits in the upper part of the Middle Jurassic succession and the backstepping stacking pattern of the uppermost three sequences indicate that not only punctuated rift-related subsidence but also a large-scale eustatic sea-level rise or regional subsidence participated in the creation of accommodation space. The important sequence boundary at the base of the Cal-1A sequence, which formed in late Bathonian or earliest Callovian times, cuts deeply into deposits both on the upper hangingwall slope and in basinal locations close to the main boundary fault. This sequence boundary can be traced into the southern part of the Danish Central Graben (Michelsen et al. 2003, this volume, fig. 36). This supports the suggestion that a regional fall in relative sea level rather than local rift-related tectonics is responsible for the formation of that sequence boundary.

As a result of the tectonic influence on sedimentation in the latter part of the Middle Jurassic, both estuarine and shoreface depositional systems, which may both contain important reservoir rocks, show a systematic distribution pattern that is related to the halfgraben geometry of the basin and therefore potentially predictable. Shore and shoreface sandstones of the HST and FSST in the uppermost sequences occur as strikeparallel laterally extensive sheet sandstones. They can be correlated with negligible changes in thickness, grain size and facies for at least $15 \mathrm{~km}$ in the Danish Søgne Basin. In contrast, thick estuarine channel deposits of the TST in the uppermost sequences mainly occur in dip-parallel incised valleys. 


\section{Acknowledgements}

This study formed part of a Ph.D. undertaken at Copenhagen University. I am grateful to my supervisor Finn Surlyk for his thorough constructive critisism, which contributed significantly to the improvement of this paper, to reviewers Jan Alexander and Guy Plint for their helpful comments and to Jon Ineson for thorough editing. The work was supported by EFP-92 grant no. 1313/92-0002 from the Danish Energy Agency and by Mærsk Oil and Gas A/S and Norsk Hydro Udforskning A/S. I had fruitful discussions with colleagues Karen Dybkjær, Jon R. Ineson, Peter Johannessen and Lars H. Nielsen. Karen Dybkjær and Niels Poulsen kindly supplied me with palynological datings.

\section{References}

Alexander, J. \& Gawthorpe, R.L. 1993: The complex nature of a Jurassic multi-storey alluvial sandstone body, Whitby, North Yorkshire. In: North, C.P. \& Prosser, D.J. (eds): Characterization of fluvial and aeolian reservoirs. Geological Society Special Publication (London) 73, 123-142.

Alexander, J. \& Leeder, M.R. 1987: Active tectonic control on alluvial architecture. In: Ethridge, F.G., Flores, R.M. \& Harvey, M.D. (eds): Recent developments in fluvial sedimentology. Society of Economic Paleontologists and Mineralogists Special Publication 39, 243-252.

Andsbjerg, J. 1997: Sedimentology and sequence stratigraphy of Middle Jurassic deposits, Danish and Norwegian Central Graben, 165 pp. Unpublished Ph.D. thesis, University of Copenhagen, Denmark.

Andsbjerg, J. \& Dybkjær, K. 2003: Sequence stratigraphy of the Jurassic of the Danish Central Graben. In: Ineson, J.R. \& Surlyk, F. (eds): The Jurassic of Denmark and Greenland. Geological Survey of Denmark and Greenland Bulletin 1, 265-300 (this volume).

Andsbjerg, J., Nielsen, L.H., Johannessen, P.N. \& Dybkjær, K. 2001: Divergent development of two neighbouring basins following the Jurassic North Sea doming event: the Danish Central Graben and the Norwegian-Danish Basin. In: Martinsen, O.J. \& Dreyer, T. (eds): Sedimentary environments offshore Norway - Palaeozoic to Recent. Norwegian Petroleum Society (NPF) Special Publication 10, 175-197.

Bourgeois, J. \& Leithold, E.L. 1984: Wave-worked conglomerates - depositional processes and criteria for recognition. In: Koster, E.H. \& Steel, R.J. (eds): Sedimentology of gravel and conglomerates. Canadian Society of Petroleum Geologists Memoir 10, 331-343.

Cartwright, J. 1991: The kinematic evolution of the Coffee Soil Fault. In: Roberts, A.M., Yielding, G. \& Freeman, B. (eds): The geometry of normal faults. Geological Society Special Publication (London) 56, 29-40.

Cloetingh, S. 1988: Intraplate stresses: a new element in basin analysis. In: Kleinspehn, K.L. \& Paola, C. (eds): New perspectives in basin analysis, 205-230. New York: Springer Verlag.

Dalrymple, R.W., Zaitlin B.A. \& Boyd, R.A. 1992: Estuarine facies models: conceptual basis and stratigraphic implications. Journal of Sedimentary Petrology 62, 1130-1146.

Damtoft, K., Nielsen, L.H., Johannessen, P.N., Thomsen, E. \& Andersen, P.R. 1992: Hydrocarbon plays of the Danish Central Trough. In: Spencer, A.M. (ed.): Generation, accumulation and production of Europe's hydrocarbons II. European Association of Petroleum Geoscientists Special Publication 2, 35-58.

Dreyer, T., Martinsen, O.J. \& Ryseth, A.E. 1995: Sequence stratigraphic analysis of alluvial successions: outcrop examples and subsurface applications. In: Predictive high-resolution stratigraphy, Norwegian Petroleum Society (NPF), Stavanger, Norway, 6-8 November, 1995. Abstracts, 11 only.

Eynon, G. 1981: Basin development and sedimentation in the Middle Jurassic of the northern North Sea. In: Illing, L.V. \& Hobson, G.D. (eds): Petroleum geology of the continental shelf of North-West Europe: proceedings of the 2nd conference, 196-204. London: Heyden \& Son Ltd.

Fenies, H. \& Faugères, J.-C. 1998: Facies and geometry of tidal channel-fill deposits (Arcachon Lagoon, SW France). Marine Geology 150, 131-148.

Fenies, H. \& Tastet, J.-P. 1998: Facies and architecture of an estuarine tidal bar (the Trompeloup bar, Gironde estuary, SW France). Marine Geology 150, 149-169.

Frandsen, N. 1986: Middle Jurassic deltaic and coastal deposits in the Lulu-1 well of the Danish Central Trough. Danmarks Geologiske Undersøgelse Serie A 9, 23 pp.

Gatliff, R.W. et al. 1994: United Kingdom offshore regional report: the geology of the central North Sea, 110 pp. London: Her Majesty's Stationery Office for the British Geological Survey.

Gowers, M.B. \& Sæbøe, A. 1985: On the structural evolution of the Central Trough in the Norwegian and Danish sectors of the North Sea. Marine and Petroleum Geology 2, 298-318.

Gradstein, F.M., Agterberg, F.P., Ogg, J.G., Hardenbol, J., van Veen, P., Thierry, J. \& Huang, Z. 1994: A Mesozoic time scale. Journal of Geophysical Research 99, 24051-24074.

Graue, E., Helland-Hansen, W., Johnsen, J., Lømo, L., Nøttvedt, A., Rønning, K., Ryseth, A. \& Steel, R. 1987: Advance and retreat of Brent delta system, Norwegian North Sea. In: Brooks, J. \& Glennie, K.W. (eds): Petroleum geology of North West Europe, 915-937. London: Graham \& Trotman.

Guion, P.D., Fulton, I.M. \& Jones, N.S. 1995: Sedimentary facies of the coal-bearing Westphalian A and B of the Wales - Brabant High. In: Whateley, M.K.G. \& Spears, D.A. (eds): European coal geology. Geological Society Special Publication (London) 82, 45-78.

Hallam, A. 1988: A reevaluation of Jurassic eustacy in the light of new data and the revised Exxon curve. In: Wilgus, C.K. et al. (eds): Sea-level changes - an integrated approach. Society of Economic Paleontologists and Mineralogists Special Publication 42, 261-273.

Hampson, G.J., Davies, S.J., Elliott, T., Flint, S.S. \& Stollhofen, H. 1999: Incised valley fill sandstone bodies in Upper Carboniferous fluvio-deltaic strata: recognition and reservoir char- 
acterization of southern North Sea analogues. In: Fleet, A.J. \& Boldy, S.A.R. (eds): Petroleum geology of Northwest Europe: proceedings of the 5 th conference, 771-788. London: Geological Society.

Hancock, N.J. \& Fisher, M.J. 1981: Middle Jurassic North Sea deltas with particular reference to Yorkshire. In: Illing, L.V. \& Hobson, G.D. (eds): Petroleum geology of the continental shelf of North-West Europe: proceedings of the 2nd conference, 186-195. London: Heyden \& Son Ltd.

Helland-Hansen, W. \& Martinsen, O.J. 1996: Shoreline trajectories and sequences: description of variable depositional-dip scenarios. Journal of Sedimentary Research 66, 670-688.

Herngreen, G.F.W., Kouwe, W.F.P. \& Wong, T.E. 2003: The Jurassic of the Netherlands. In: Ineson, J.R. \& Surlyk, F. (eds): The Jurassic of Denmark and Greenland. Geological Survey of Denmark and Greenland Bulletin 1, 217-229 (this volume).

Hunt, D. \& Tucker, M.E. 1992: Stranded parasequences and the forced regressive wedge systems tract: deposition during baselevel fall. Sedimentary Geology 81, 1-9.

Hunt, D. \& Tucker, M.E. 1995: Stranded parasequences and the forced regressive wedge systems tract: deposition during baselevel fall - reply. Sedimentary Geology 95, 147-160.

Japsen, P., Britze, P. \& Andersen, C. 2003: Upper Jurassic - Lower Cretaceous of the Danish Central Graben: structural framework and nomenclature. In: Ineson, J.R. \& Surlyk, F. (eds): The Jurassic of Denmark and Greenland. Geological Survey of Denmark and Greenland Bulletin 1, 233-246 (this volume).

Jensen, T.F., Holm, L., Frandsen, N. \& Michelsen, O. 1986: Jurassic - Lower Cretaceous lithostratigraphic nomenclature for the Danish Central Trough. Danmarks Geologiske Undersøgelse Serie A 12, 65 pp.

Johannessen, P.N. \& Andsbjerg, J. 1993: Middle to Late Jurassic basin evolution and sandstone reservoir distribution in the Danish Central Trough. In: Parker, J.R. (ed.): Petroleum geology of Northwest Europe: proceedings of the 4th conference, 271-283. London: Geological Society.

Koch, J.-O. 1983: Sedimentology of Middle and Upper Jurassic sandstone reservoirs of Denmark. In: Kaasschieter, J.P.H. \& Reijers, T.J.A. (eds): Petroleum geology of the southeastern North Sea and the adjacent onshore areas. Geologie en Mijnbouw 62, 115-129.

Korstgaard, J.A., Lerche, I., Mogensen, T.E. \& Thomsen, R.O. 1993: Salt and fault interactions in the northeastern Danish Central Graben: observations and inferences. Bulletin of the Geological Society of Denmark 40, 197-255.

Leeder, M.R. \& Gawthorpe, R.L. 1987: Sedimentary models for extensional tilt-block/half-graben basins. In: Coward, M.P., Dewey, J.F. \& Hancock, P.L. (eds): Continental extensional tectonics. Geological Society Special Publication (London) 28, 139-152.

MacLennan, A.M. \& Trewin, N.H. 1989: Palaeoenvironments of the late Bathonian - mid-Callovian in the Inner Moray Firth. In: Batten, D.J. \& Keen, M.C. (eds): Northwest European micropalaeontology and palynology, 92-117. British Micropalaeontological Society Series. Chichester: Ellis Horwood.

Miall, A.D. 1997: The geology of stratigraphic sequences, 433 pp. Berlin: Springer Verlag.

Michelsen, O., Mogensen, T.E. \& Korstgaard, J.A. 1992: Pre-
Cretaceous structural development of the Danish Central Trough and its implications for the distribution of Jurassic sands. In: Larsen, R.M. et al. (eds): Structural and tectonic modelling and its application to petroleum geology. Norwegian Petroleum Society (NPF) Special Publication 1, 495-506.

Michelsen, O., Nielsen, L.H., Johannessen, P.N., Andsbjerg, J. \& Surlyk, F. 2003: Jurassic lithostratigraphy and stratigraphic development onshore and offshore Denmark. In: Ineson, J.R. \& Surlyk, F. (eds): The Jurassic of Denmark and Greenland. Geological Survey of Denmark and Greenland Bulletin 1, 147-216 (this volume).

Mogensen, T.E., Korstgaard, J.A. \& Geil, K. 1992: Salt tectonics and faulting in the NE Danish Central Graben. In: Spencer, A.M. (ed.): Generation, accumulation and production of Europe's hydrocarbons II. European Association of Petroleum Geoscientists Special Publication 2, 163-173.

Møller, J.J. 1986: Seismic structural mapping of the Middle and Upper Jurassic in the Danish Central Trough. Danmarks Geologiske Undersøgelse Serie A 13, 37 pp.

NAM \& RGD 1980: Stratigraphic nomenclature of the Netherlands. Verhandelingen van het Koninklijk Nederlands Geologischen Mijnbouwkundig Genootschap 32, 77 pp. (Nederlandse Aardolie Maatschappij \& Rijks Geologische Dienst).

Nichol, S.L. \& Boyd, R. 1993: Morphostratigraphy and facies architecture of sandy barriers along the eastern shore of Nova Scotia. Marine Geology 114, 59-80.

Nielsen, L.H. 2003: Late Triassic - Jurassic development of the Danish Basin and the Fennoscandian Border Zone, southern Scandinavia. In: Ineson, J.R. \& Surlyk, F. (eds): The Jurassic of Denmark and Greenland. Geological Survey of Denmark and Greenland Bulletin 1, 459-526 (this volume).

Nummedal, D. \& Molenaar, C.M. 1995: Sequence stratigraphy of ramp-setting strand-plain successions: the Gallup Sandstone, New Mexico. In: Van Wagoner, J.C. \& Bertram, G.T. (eds): Sequence stratigraphy of foreland basin deposits - outcrop and subsurface examples from the Cretaceous of North America. American Association of Petroleum Geologists Memoir 64 , 277-310.

Olsen, T., Steel, R.J., Høgseth, K., Skar, T. \& Røe, S-L. 1995: Sequence architecture in a fluvial succession: sequence stratigraphy in the Upper Cretaceous Mesaverde Group, Price Canyon, Utah. Journal of Sedimentary Research 65, 265-280.

Petersen, H.I. \& Andsbjerg, J. 1996: Organic facies development within Middle Jurassic coal seams, Danish Central Graben, and evidence for relative sea-level control on peat accumulation in a coastal plain environment. Sedimentary Geology 106, 259-277.

Plint, A.G. 1988: Sharp-based shoreface sequences and 'offshore bars' in the Cardium Formation of Alberta: their relationship to relative changes in sea level. In: Wilgus, C.K. et al. (eds): Sea-level changes - an integrated approach. Society of Economic Paleontologists and Mineralogists Special Publication 42, 357-370.

Posamentier, H.W. \& Vail, P.R. 1988: Eustatic controls on clastic deposition II - sequence and systems tract models. In: Wilgus, C.K. et al. (eds): Sea-level changes - an integrated approach. Society of Economic Paleontologists and Mineralogists Special Publication 42, 125-154. 
Posamentier, H.W., Jervey, M.T. \& Vail, P.R. 1988: Eustatic controls on clastic deposition I - conceptual framework. In: Wilgus, C.K. et al. (eds): Sea-level changes - an integrated approach. Society of Economic Paleontologists and Mineralogists Special Publication 42, 109-124.

Posamentier, H.W., Allen, G.P., James, D.P. \& Tesson, M. 1992: Forced regressions in a sequence stratigraphic framework: concepts, examples, and exploration significance. American Association of Petroleum Geologists Bulletin 76, 1687-1709.

Ravnås, R. \& Steel, R.J. 1998: Architecture of marine rift-basin successions. American Association of Petroleum Geologists Bulletin 82, 110-146.

Rawson, P.F. \& Wright, J.K. 1995: Jurassic of the Cleveland Basin, North Yorkshire. In: Taylor, P.D. (ed.): Field geology of the British Jurassic, 173-208. London: Geological Society.

Reineck, H.E. \& Wunderlich, F. 1968: Classification and origin of flaser and lenticular bedding. Sedimentology 11, 99-104.

Schwartz, R.K. 1982: Bedform and stratification characteristics of some modern small-scale washover sand bodies. Sedimentology 29, 835-849.

Shanley, K.W. \& McCabe, P.J. 1991: Predicting facies architecture through sequence stratigraphy - an example from the Kaiparowits Plateau, Utah. Geology 19, 742-745.

Shanley, K.W. \& McCabe, P.J. 1993: Alluvial architecture in a sequence stratigraphic framework: a case history from the Upper Cretaceous of southern Utah, USA. International Association of Sedimentologists Special Publication 15, 21-56.

Shanley, K.W. \& McCabe, P.J. 1994: Perspectives on the sequence stratigraphy of continental strata. American Association of Petroleum Geologists Bulletin 78, 544-568.

Smith, D.G. 1987: Meandering river point bar lithofacies models: modern and ancient examples compared. In: Ethridge, F.G., Flores, R.M. \& Harvey, M.D. (eds): Recent developments in fluvial sedimentology. Society of Economic Paleontologists and Mineralogists Special Publication 39, 83-91.

Stephen, K.J. \& Davies, R.J. 1998: Documentation of Jurassic sedimentary cycles from the Moray Firth basin, United Kingdom North Sea. In: de Graciansky, P.-C. et al. (eds): Mesozoic and Cenozoic sequence stratigraphy of European basins. SEPM (Society for Sedimentary Geology) Special Publication 60, 481-506.

Sundsbø, G.O. \& Megson, J.B. 1993: Structural styles in the Danish Central Graben. In: Parker, J.R. (ed.): Petroleum geology of Northwest Europe: proceedings of the 4th conference, 1255-1267. London: Geological Society.

Thomas, R.G., Smith, D.G., Wood, J.M., Visser, J., Calverley-Range, E.A. \& Koster, E.H. 1987: Inclined heterolithic stratification terminology, description, interpretation and significance. Sedimentary Geology 53, 123-179.

Underhill, J.R. \& Partington, M.A. 1993: Jurassic thermal doming and deflation in the North Sea: implications of the sequence stratigraphic evidence. In: Parker, J.R. (ed.): Petroleum geol- ogy of Northwest Europe: proceedings of the 4th conference, 337-345. London: Geological Society.

Vail, P.R., Mitchum, R.M. \& Thompson, S. 1977: Seismic stratigraphy and global changes of sea level; Part 3: Relative changes in sea level from coastal onlap. In: Payton, C.E. (ed.): Seismic stratigraphy - applications to hydrocarbon exploration. American Association of Petroleum Geologists Memoir 26, 63-97.

van Adrichem Boogaert, H.A. \& Kouwe, W.F.P. (compilers) 1993: Lower and Middle Jurassic (Altena Group). In: van Adrichem Boogaert, H.A. \& Kouwe, W.F.P. (compilers): Stratigraphic nomenclature of the Netherlands, revision and update by Rijks Geologische Dienst and Netherlands Oil and Gas Exploration and Production Association. Mededelingen Rijks Geologische Dienst 50(section F), 20 pp.

Van Wagoner, J.C., Posamentier, H.W., Mitchum, R.M., Vail, P.R., Sarg, J.F., Loutit, T.S. \& Hardenbol, J. 1988: An overview of the fundamentals of sequence stratigraphy and key definitions. In: Wilgus, C.K. et al. (eds): Sea-level changes - an integrated approach. Society of Economic Paleontologists and Mineralogists Special Publication 42, 39-45.

Van Wagoner, J.C., Mitchum, R.M., Campion, K.M. \& Rahmanian, V.D. 1990: Siliciclastic sequence stratigraphy in well logs, cores and outcrops: concepts for high-resolution correlation of time and facies. American Association of Petroleum Geologists Methods in Exploration Series 7, 55 pp.

Visser, M.J. 1980: Neap-spring cycles reflected in Holocene subtidal large-scale bedform deposits: a preliminary note. Geology 8, 543-546.

Vollset, J. \& Doré, A.G. (eds) 1984: A revised Triassic and Jurassic lithostratigraphic nomenclature for the Norwegian North Sea. Norwegian Petroleum Directorate Bulletin 3, 53 pp.

Whiteman, A.J., Rees, G., Naylor, D. \& Pegrum, R.M. 1975: North Sea troughs and plate tectonics. Norges Geologiske Undersøkelse 316, 137-161.

Wright, V.P. \& Marriot, S.B. 1993: The sequence stratigraphy of fluvial depositional systems: the role of floodplain sediment storage. Sedimentary Geology 86, 203-210.

Zaitlin, B.A., Dalrymple, R.W. \& Boyd, R. 1994: The stratigraphic organization of incised-valley systems associated with relative sea-level change. In: Dalrymple, R.W., Boyd, R. \& Zaitlin, B.A. (eds): Incised-valley systems: origin and sedimentary sequences. SEPM (Society for Sedimentary Geology) Special Publication 51, 45-60.

Ziegler, P.A. 1982: Geological atlas of western and central Europe, 130 pp. The Hague: Elsevier for Shell Internationale Petroleum Maatschappij.

Ziegler, P.A. 1990: Tectonic and palaeogeographic development of the North Sea rift system. In: Blundell, D.J. \& Gibbs, A.D. (eds): Tectonic evolution of the North Sea rifts, 1-36. Oxford: Clarendon Press. 


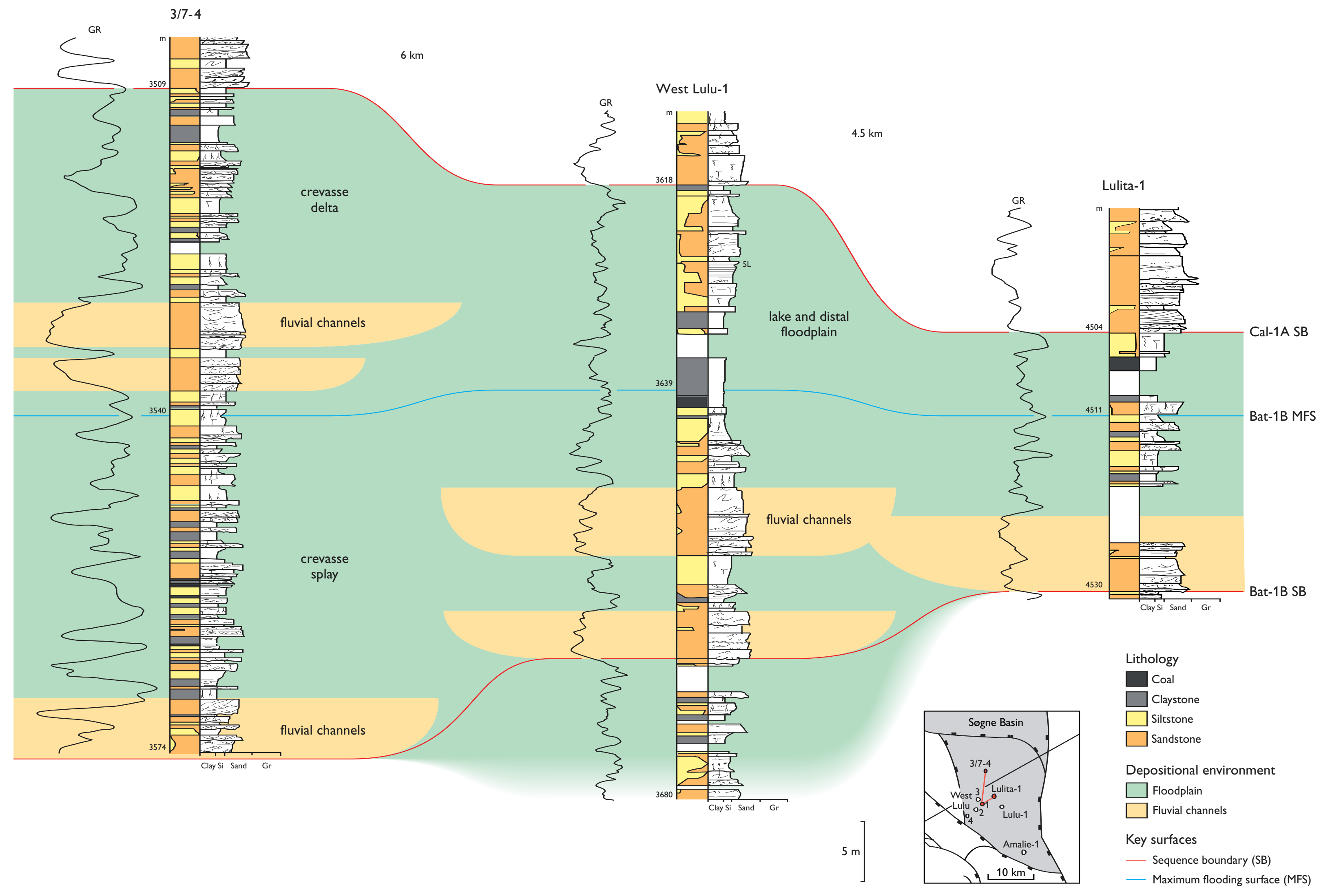

Fig. 15. Log panel (GR and core logs) depiciting
floodplain deposist with channel and crevasse

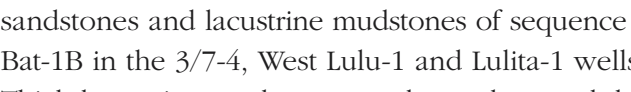

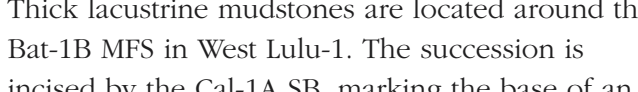
incised by the Cal-1A $S B$, marking the base of an
incised valley. The positions of cores illustrated incised valley. The positions of cores illustrats
with photographs here are indiciated on the

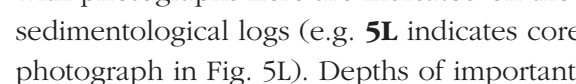
surfaces, facies changes or core breaks are
ndicated (in mertes below reference level). Fe

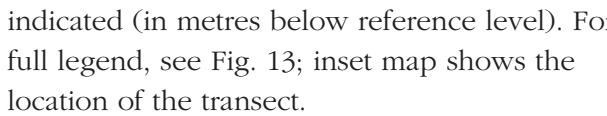




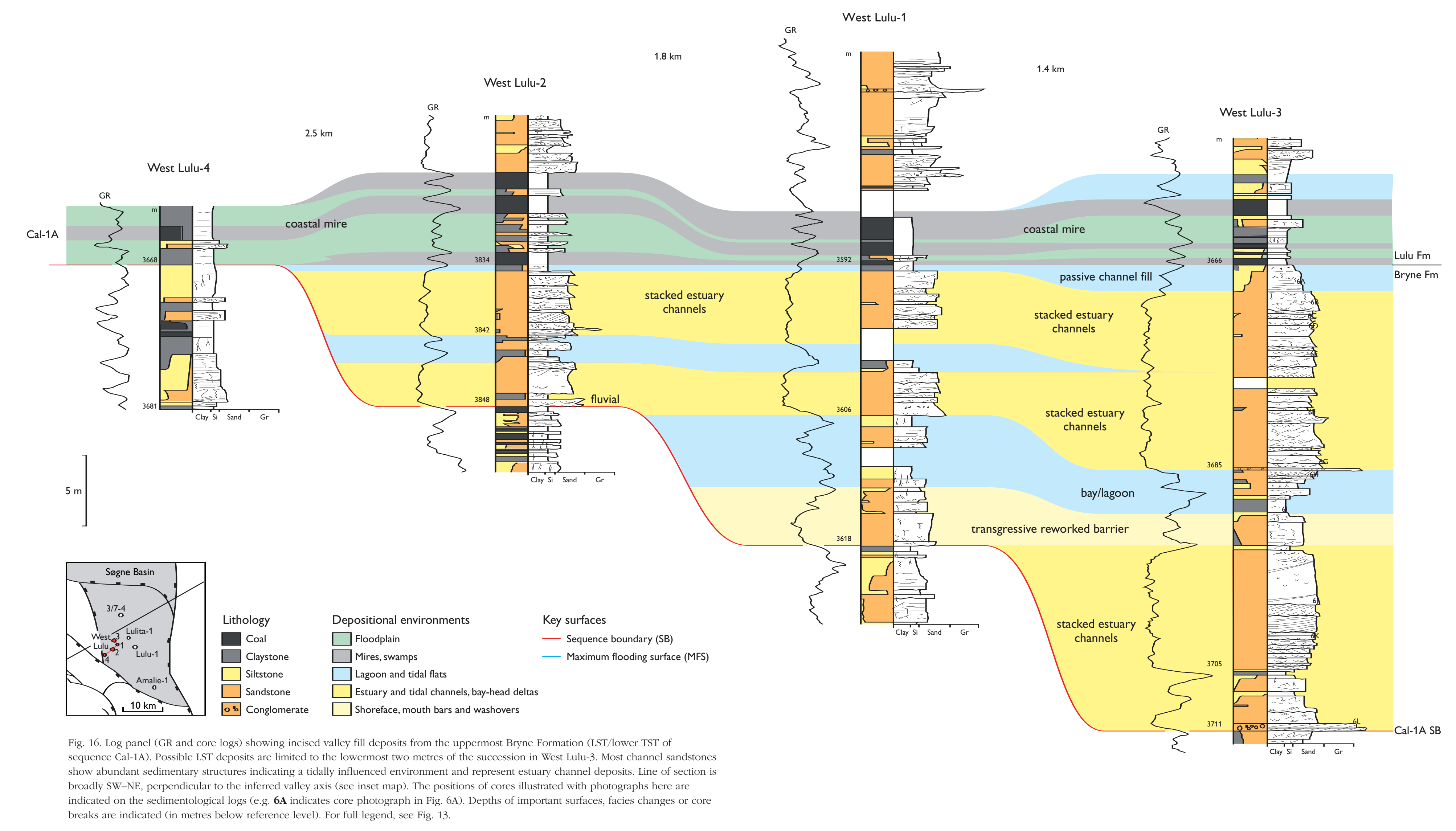




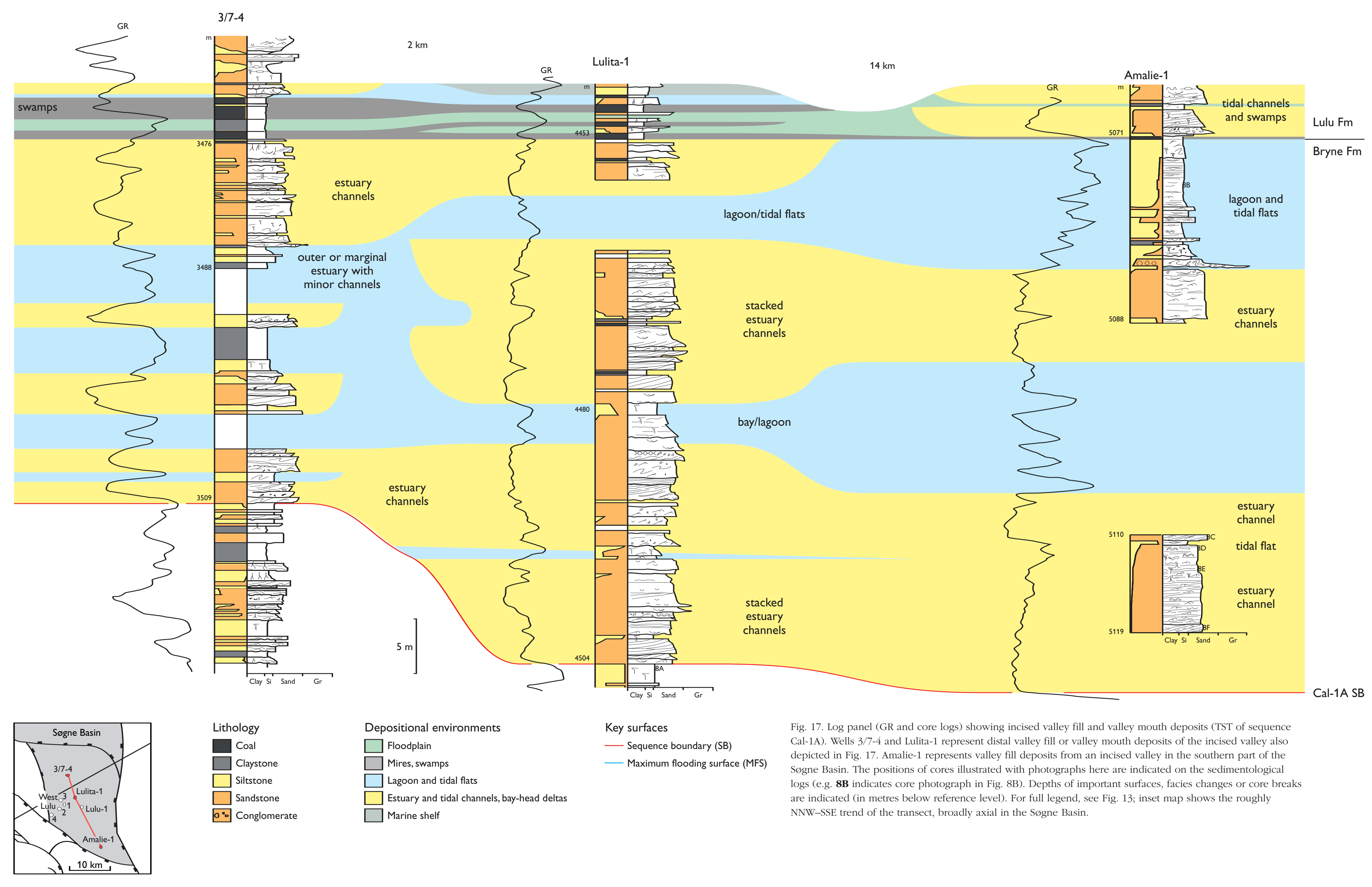




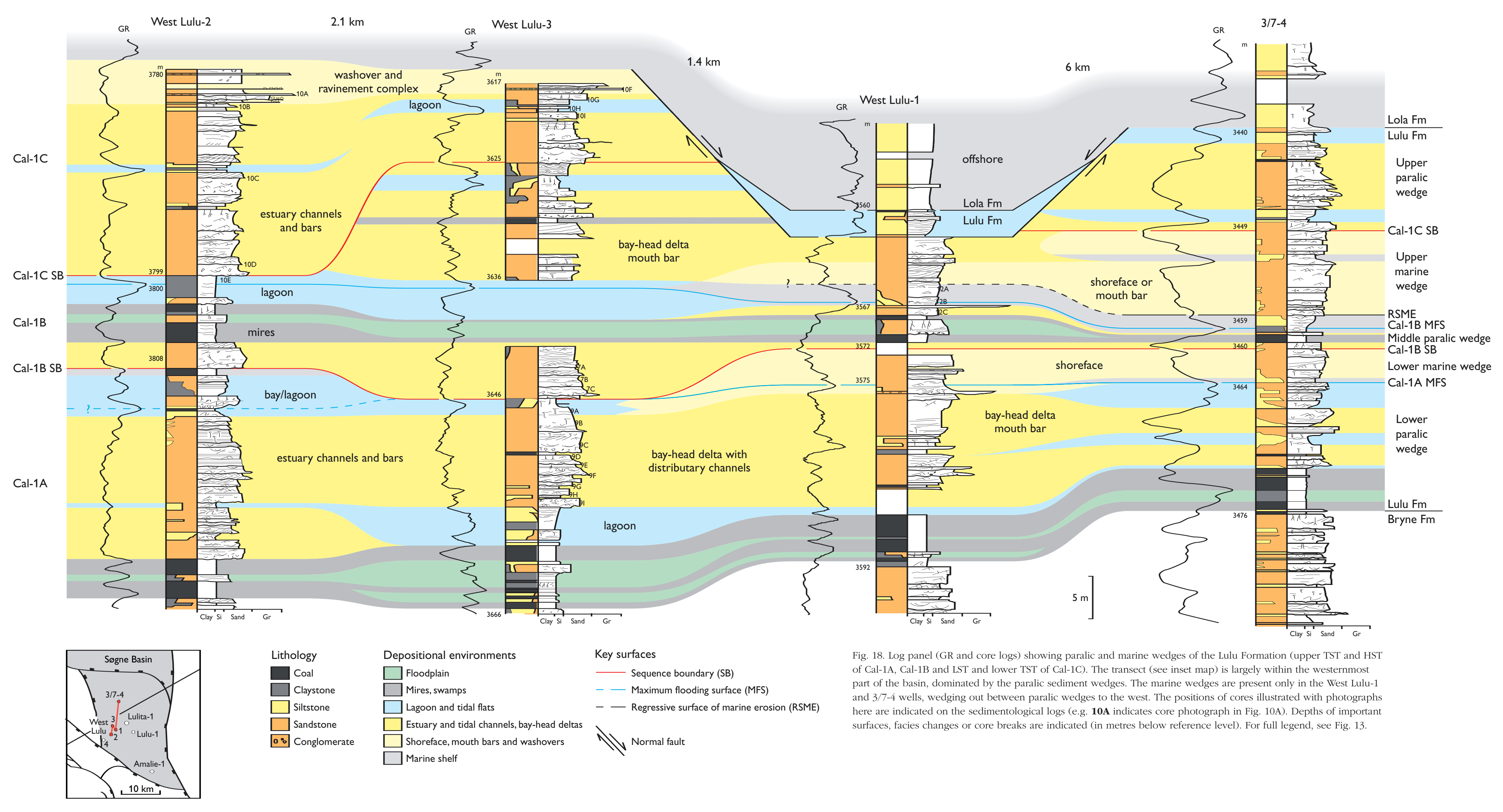




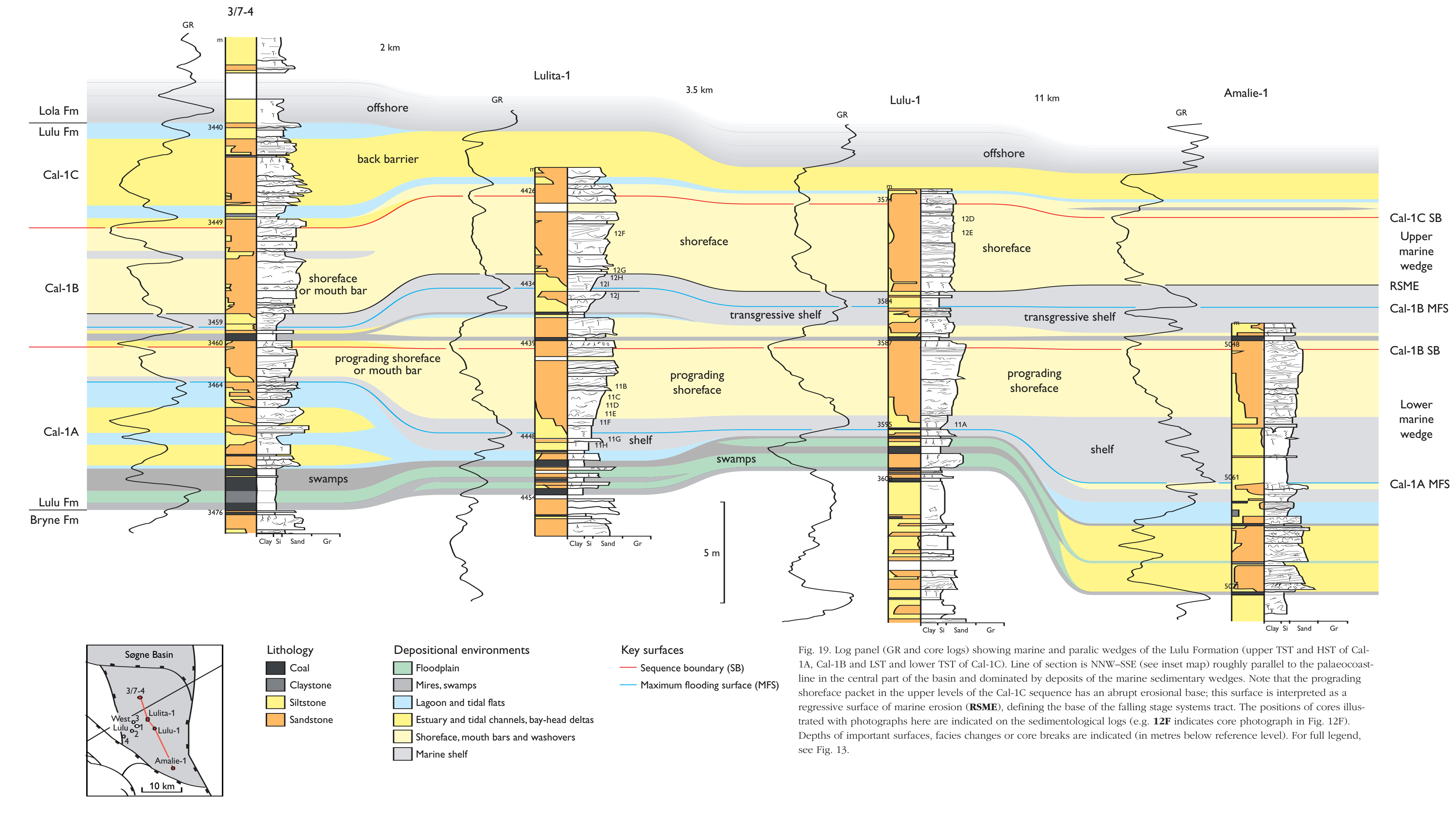

